This item was submitted to Loughborough's Research Repository by the author.

Items in Figshare are protected by copyright, with all rights reserved, unless otherwise indicated.

\title{
Structured microparticles with tailored properties produced by membrane emulsification
}

PLEASE CITE THE PUBLISHED VERSION

http://dx.doi.org/10.1016/j.cis.2015.07.013

\section{PUBLISHER}

(C) Elsevier B.V.

VERSION

AM (Accepted Manuscript)

\section{PUBLISHER STATEMENT}

This work is made available according to the conditions of the Creative Commons Attribution-NonCommercialNoDerivatives 4.0 International (CC BY-NC-ND 4.0) licence. Full details of this licence are available at: https://creativecommons.org/licenses/by-nc-nd/4.0/

\section{LICENCE}

CC BY-NC-ND 4.0

\section{REPOSITORY RECORD}

Vladisavljevic, Goran T.. 2015. "Structured Microparticles with Tailored Properties Produced by Membrane Emulsification”. figshare. https://hdl.handle.net/2134/18895. 


\title{
Structured microparticles with tailored properties produced by membrane emulsification
}

\author{
Goran T. Vladisavljevića ${ }^{\mathrm{ab}}$
}

${ }^{a}$ Chemical Engineering Department, Loughborough University, Loughborough, Leicestershire LE11 3TU, United Kingdom, Email: G.Vladisavljevic@lboro.ac.uk. ${ }^{b}$ Laboratory of Chemical Dynamics, Vinča Institute of Nuclear Sciences, University of Belgrade, P.O. Box 522, 11001 Belgrade, Serbia

\begin{abstract}
This paper provides an overview of membrane emulsification routes for fabrication of structured microparticles with tailored properties for specific applications. Direct (bottom-up) and premix (top-down) membrane emulsification processes are discussed including operational, formulation and membrane factors that control the droplet size and droplet generation regimes. A special emphasis was put on different methods of controlled shear generation on membrane surface, such as cross flow on the membrane surface, swirl flow, forward and backward flow pulsations in the continuous phase and membrane oscillations and rotations. Droplets produced by membrane emulsification can be used for synthesis of particles with versatile morphology (solid and hollow, matrix and core/shell, spherical and non-spherical, porous and coherent, composite and homogeneous), which can be surface functionalised and coated or loaded with macromolecules, nanoparticles, quantum dots, drugs, phase change materials and high molecular weight gases to achieve controlled/targeted drug release and impart special optical, chemical, electrical, acoustic, thermal and magnetic properties. The template emulsions including metal-in-oil, solid-in-oil-in-water, oil-in-oil, multilayer, and Pickering emulsions can be produced with high encapsulation efficiency of encapsulated materials and narrow size distribution and transformed into structured particles using a variety of different processes, such as polymerisation (suspension, mini-emulsion, interfacial and in-situ), ionic gelation, chemical crosslinking, melt solidification, internal phase separation, layer-by-layer electrostatic deposition, particle self-assembly, complex coacervation, spray drying, sol-gel processing, and molecular imprinting. Particles fabricated from droplets produced by membrane emulsification include nanoclusters, colloidosomes, carbon aerogel particles, nanoshells, polymeric (molecularly imprinted, hypercrosslinked, Janus and core/shell) particles, solder metal powders and inorganic particles. Membrane
\end{abstract}


emulsification devices operate under constant temperature due to low shear rates on the membrane surface, which range from $(1-10) \times 10^{3} \mathrm{~s}^{-1}$ in a direct process to $(1-10) \times 10^{4} \mathrm{~s}^{-1}$ in a premix process.

Keywords: Membrane Emulsification; Polymeric microsphere; Microgel; Janus Particle; Core/Shell Particle, Colloidosome.

\section{Membrane emulsification}

Membrane emulsification (ME) involves preparation of emulsions by pressing a pure dispersed phase or pre-emulsified mixture of the dispersed and continuous phase through a microporous membrane under controlled injection rate and shear conditions. In direct membrane emulsification (DME), one liquid (a dispersed phase) is injected through a microporous membrane into another immiscible liquid (the continuous phase) (Nakashima et al., 1991; 2000), which leads to the formation of droplets at the membrane/continuous phase interface (Figure 1a). In premix membrane emulsification (PME) (Figure 1b), a pre-emulsion is pressed through the membrane (Suzuki et al., 1996) or a packed bed of uniform particles (van der Zwan et al., 2008; Yasuda et al., 2010; Laouini et al., 2014), which leads to homogenisation of existing coarse droplets. If the transmembrane pressure is lower than the capillary pressure, the pressure force acting on a droplet will not be able to squeeze the droplet through a pore, which will lead to the separation of the pre-emulsion into a dropletfree continuous phase and concentrated emulsion (Koltuniewicz et al., 1995; Park et al., 1998). Hydrophobic membranes are needed to produce water-in-oil (W/O) (Cheng et al., 2008; Jing et al., 2006) and oil-in-water-in-oil (O/W/O) (Wei et al., 2013) emulsions and hydrophilic membranes are required to prepare oil-in-water $(\mathrm{O} / \mathrm{W})$ and water-in-oil-in-water $(\mathrm{W} / \mathrm{O} / \mathrm{W})$ (Vladisavljević et al., 2014) emulsions. The advantages of PME over DME are in smaller droplet sizes and higher transmembrane fluxes that can be achieved for any given pore size and higher dispersed phase content that can be obtained (up to 60 vol\% in simple PME and up to 90 vol\% in PME with phase inversion (Suzuki et al., 1999)). On the other hand, PME gives broader particle size distribution with a more severe membrane fouling and operates at higher transmembrane pressures. The main limitations of ME for industrial scale production are in low emulsion throughputs and membrane fouling (Piacentini et al., 2014). In order to produce $1 \mathrm{~m}^{3} \mathrm{~h}^{-1}$ of a $30 \%$ emulsion with a droplet size of $5-10 \mu \mathrm{m}$, the required membrane area in shear-based DME is 5-60 m² (Schroën et al., 2015). 


\subsection{Comparison of membrane and conventional emulsification}

Compared to high-shear rotor-stator mixers, high-pressure valve homogenizers, ultrasonic and static mixers, ME devices operate under constant temperature due to mild shear conditions, keeping heat and shear- sensitive ingredients intact and providing high encapsulation yields of multiple emulsions (Surh et al., 2007; Vladisavljević and Williams, 2008; Dragosavac et al., 2012). Conventional homogenisation devices apply high specific energy inputs to disrupt droplets (Karbstein and Schubert, 1995), which leads to an increase in the temperature of an emulsion, because a significant amount of the mechanical energy is converted into heat due to viscous dissipation (McClements, 2005). In DME, shear rate on the membrane surface is $(1-10) \times 10^{3} \mathrm{~s}^{-1}$ but uniform droplets can be produced even without any shearing, simply by spontaneous droplet formation through Laplace pressure differences (Kukizaki, 2009; Kukizaki and Goto, 2009; Kosvintsev et al., 2008; Maan et al., 2011). In PME, the shear rate inside the pores of SPG membrane is $(1-10) \times 10^{4} \mathrm{~s}^{-1}$. As a comparison, a shear rate in highshear in-line mixers and colloid mills is about $10^{5} \mathrm{~s}^{-1}$ and can exceed $10^{7} \mathrm{~s}^{-1}$ in microfluidizers ${ }^{\circledR}$. In PME, the energy input per unit volume is $0.05-5 \mathrm{~kJ} \mathrm{dm}^{-3}$, which is $1-2$ orders of magnitude smaller than in high-pressure valve homogenizers $\left(3-20 \mathrm{~kJ} \mathrm{dm}^{-3}\right)$.

In conventional emulsification devices energy input is not spatially uniform. For example, in rotor-stator devices, shear forces are high in close proximity to a rotor and low in "dead zones”, leading to droplet size polydispersity. In most ME systems (e.g. cross-flow), shear stress is uniformly distributed over the membrane surface and localised to the membrane wall rather than the entire bulk volume of the fluid. A Computational Fluid Dynamics (CFD) analysis has shown that in an azimuthally oscillating membrane emulsification system, shear rate becomes negligible at radial distances from the membrane surface of just $0.5 \mathrm{~mm}$ although the shear rate could be $1400 \mathrm{~s}^{-1}$ at the membrane surface (Silva et al., 2015). Due to controlled localised shear and geometrically-mediated drop formation, the droplet size can be precisely controlled over a wide range and a narrow droplet size distribution can be achieved. Membrane devices can be integrated with downstream processing to achieve a simultaneous drop generation and chemical/biochemical conversion or physicochemical transformation in the formed droplets. The examples include integration of $\mathrm{ME}$ with liquid-liquid extraction (Chen et al., 2004, Xu et al., 2005), biphasic enzymatic transformation (Li and Sakaki, 2008; 
Mazzei et al., 2010), pervaporation (Chang and Hatton, 2012), and complex coacervation (Piacentini et al., 2013).

\section{Membranes for preparation of emulsions and particles}

Membranes used for preparation of emulsions should have the following properties: (i) uniform pore size distribution with a wide range of available mean pore sizes to obtain uniform droplets with tuneable sizes; (ii) low hydrodynamic resistance; (iii) high mechanical strength and thermal and chemical resistance; (iv) high tolerance to organic solvents used in product formulation to suit different applications; (v) ease of surface modification and functionalization to modify their wettability, charge, permeability, etc; (vi) ability to keep constant wettability in contact with the dispersed and continuous phase; (vii) low fabrication costs per unit membrane area. In this section only membranes most commonly used in membrane dispersion processes will be discussed.

\subsection{SPG membrane}

Shirasu Porous Glass (SPG) meets the majority of the above criteria and it is the most widely used microporous membrane used for emulsification. Advantages of SPG membrane over microengineered membranes are in higher porosity, more versatile surface chemistry that can be implemented, a broader range of commercially available mean pore sizes, and lower fabrication costs. For a constant fraction of active pores, the higher the membrane porosity, the lower the dispersed phase velocity in the pores at any dispersed phase flow rate, and the higher the likelihood that the dripping regime will persist in DME. However, high membrane porosity can promote droplet-droplet interactions on the membrane surface, such as steric hindrance of droplets forming simultaneously, which can compromise droplet size uniformity (Abrahamse et al., 2002).

\subsubsection{Fabrication of SPG membrane}

SPG membrane is fabricated from $\mathrm{Na}_{2} \mathrm{O}-\mathrm{CaO}-\mathrm{Al}_{2} \mathrm{O}_{3}-\mathrm{B}_{2} \mathrm{O}_{3}-\mathrm{SiO}_{2}$ or $\mathrm{Na}_{2} \mathrm{O}-\mathrm{CaO}-\mathrm{MgO}-$ $\mathrm{Al}_{2} \mathrm{O}_{3}-\mathrm{B}_{2} \mathrm{O}_{3}-\mathrm{SiO}_{2}$ type mother glass through phase separation by spinodal decomposition (Nakashima and Kuroki, 1981; Nakashima and Shimizu, 1986; Kukizaki and Nakashima, 2004). The mother glass is prepared by mixing and melting raw materials (Shirasu, limestone, 
boric acid and soda ash) at $1300-1400{ }^{\circ} \mathrm{C}$. Typical mixing ratio of raw materials is shown in Table 1. $\mathrm{MgO}$ and $\mathrm{ZrO}_{2}$ can be added to mother glass to adjust the rate and temperature of phase separation and glass resistance to alkali. Shirasu is a volcanic ash sediment which contains $72-77 \mathrm{wt} \% \mathrm{SiO}_{2}, 10-15 \mathrm{wt} \% \mathrm{Al}_{2} \mathrm{O}_{3}$, and small amounts of other inorganic oxides (Table 2). Molten mother glass is shaped into tubes or discs, cooled to $650-760{ }^{\circ} \mathrm{C}$ and then kept at that temperature for a period of several hours to several days. The thermal treatment causes a homogeneous melt to separate into an acid-insoluble $\left(\mathrm{Al}_{2} \mathrm{O}_{3}-\mathrm{SiO}_{2}\right.$ rich) phase and acid-soluble $\left(\mathrm{CaO}-\mathrm{B}_{2} \mathrm{O}_{3}\right.$ rich) phase. The phase-separated glass is then immersed into a hydrochloric acid solution to dissolve $\mathrm{CaO}-\mathrm{B}_{2} \mathrm{O}_{3}$ rich phase, which results in the formation of porous skeleton whose composition is given in Table 2 .

The phase diagram in Figure 2 depicts the process of cooling homogeneous glass from the initial temperature $T_{1}$, which lies above the upper critical solution temperature, UCST, where all components are miscible in all proportions, to the phase separation temperature, $T_{2}$, which lies between the spinodal curve and the glass transition temperature, $T_{g}$. The mother glass with a composition of $x_{1}$ is separated into two immiscible phases with compositions of $x_{s}$ and $x_{i}$. The mass ratio of acid-soluble to acid-insoluble phase can be estimated by the lever rule: $x_{s} / x_{i}=\left(x_{i}-x_{1}\right) /\left(x_{1}-x_{s}\right)$. The mean pore diameter $d_{p}$ of SPG membrane can be controlled by the time $t$ and temperature $T_{2}$ of the heat treatment process (Kukizaki, 2010):

$$
d_{p}=4 K^{1 / 2}\left(V_{p} / m_{m}\right) t^{1 / 2} \exp \left[-E_{a} /\left(2 R T_{2}\right)\right]
$$

where $K$ is a constant depending on the composition of mother glass, $E_{a}=400-600 \mathrm{~kJ} \mathrm{~mol}^{-1}$ is the activation energy for spinodal decomposition (Nakashima, 2002; Kukizaki, 2010), $R=$ $8314 \mathrm{~kJ} \mathrm{kmol}^{-1} \mathrm{~K}^{-1}$ is the universal gas constant, and $V_{p} / m_{m}$ is the total pore volume per unit mass of dry membrane. At constant temperature, the mean pore size of SPG membrane is proportional to the square root of the heating time, whereas a logarithm of the mean pore size decreases linearly with $1 / T_{2}$ for a constant heating time. It means that small pores can be obtained by phase separation at low temperatures (but above $T_{g}$ ) for a short time.

A porosity of SPG membrane corresponds to the volume fraction $\phi_{s}$ of acid-soluble phase in phase-separated glass and is normally from 0.50 to 0.60 (Vladisavljević et al., 2005). If $\phi_{s}$ is 
outside that range, separation can takes place by the nucleation and growth mechanism, which leads to the formation of discrete spherical particles of one phase embedded in a continuous matrix of the other (Figure 2). This morphology is undesirable in membrane fabrication.

\subsubsection{Properties of SPG membrane}

SPG membrane is available from SPG Technology Ltd (Sadowara, Japan) with a mean pore size ranging from 0.040 to $40 \mu \mathrm{m}$ (Table 3). The membrane has a uniform internal microstructure, as confirmed by X-ray microtomography (Vladisavljević et al., 2007), characterised by interconnected cylindrical pores with a tortuosity factor of $\xi \approx 1$. The number of pores per unit cross-sectional area is given by (Vladisavljević et al., 2005):

$$
N / A_{m}=0.56 / d_{p}^{2}
$$

where $N / A_{m}$ and $d_{p}$ are in $\mathrm{m}^{-2}$ and $\mathrm{m}$, respectively. The hydraulic resistance of isotropic SPG membrane is given by (Vladisavljević et al., 2005):

$$
R_{m}=32 \xi^{2} \delta_{m} /\left(d_{p}^{2} \varepsilon\right)
$$

where $\delta_{m}$ is the membrane thickness and $\varepsilon$ is the membrane porosity. The hydraulic resistance of isotropic SPG membrane is high (Table 3), due to its thickness of 400-1000 $\mu \mathrm{m}$, but can be reduced by one order of magnitude if the membrane is fabricated with anisotropic structure (Kukizaki and Goto, 2007b).

A comparison of chemical composition of SPG and common porous glasses is shown in Table 2. SPG is more stable in water and alkaline solutions than Porous Vycor ${ }^{\circledR}$ Glass, because it contains less $\mathrm{SiO}_{2}$ and more $\mathrm{Al}_{2} \mathrm{O}_{3}$. However, the durability of both membranes at high $\mathrm{pH}$ is limited, due to attack of hydroxide ions on siloxane (Si-O-Si) bonds:

$\equiv \mathrm{Si}-\mathrm{O}-\mathrm{Si} \equiv+\mathrm{OH}^{-} \rightarrow \equiv \mathrm{Si}-\mathrm{O}^{-}+\equiv \mathrm{Si}-\mathrm{OH}$

Alkaline durability of SPG can be improved by incorporating $3 \mathrm{~mol} \%$ of $\mathrm{ZrO}_{2}$ into the mother glass, which results in to the formation of stable $\mathrm{Zr}-\mathrm{O}-\mathrm{Si}$ bonds in the silicate network (Kukizaki, 2010). The compressive strength of SPG of 200-280 MPa is much higher than that of a porous alumina or zirconia of the same porosity (Nakashima et al., 1992), because SPG is made up of a continuous glass skeleton with very few defects, while porous alumina or zirconia is composed of skeletal grains joined together discontinuously via grain boundaries. 


\subsubsection{Surface modification of SPG membrane}

The surface of SPG membrane can be hydrophobised by chemical reaction with organosilane compounds, such as chlorosilanes (Kukizaki and Wada, 2008) or physical coating with silicone resin (Vladisavljević et al., 2005). Monochlorosilanes such as trimethylchlorosilane (TMS) and octadecyldimethylchlorosilane (ODS) are suitable agents for hydrophobisation because they contain only one reactive chlorine atom, which means that no polymerisation between silane molecules can occur while they react with a silanol group on the glass surface (Figure 3a) (Kai et al., 2006). The longer the length of the carbon chain in an organosilane compound, more hydrophobic the membrane surface becomes (Kukizaki and Wada, 2008). The membrane hydrophobicity can be enhanced by depositing silica nanoparticles onto the surface of SPG membrane prior to treatment with TMS (Meng et al., 2013). The surface of SPG membrane can also be made with thermoresponsive hydrophilic-hydrophobic properties by depositing silica nanoparticles containing poly(N-isopropylacrylamide) (PNIPAM) brushes grafted on their surface (Meng et al., 2010). The porosity and hydraulic resistance of SPG membrane can be modified over a wide range by synthesising dextran macromolecules within the pores via in-situ enzymatic reaction between dextransucrase and sucrose (Kawakita et al., 2009; Seto et al., 2011). A reversible change in the hydraulic resistance of dextranloaded SPG membrane is a consequence of reversible extension and shrinkage of solventresponsive dextran chains inside the pores initiated by washing the membrane with water or organic solvent, respectively.

The surface of untreated SPG surface has a negative zeta potential between -15 and $-45 \mathrm{mV}$ within a pH range of $2-8$, due to dissociation of silanol groups $\left(\equiv \mathrm{Si}-\mathrm{OH} \leftrightarrows \equiv \mathrm{SiO}^{-}+\mathrm{H}^{+}\right.$) (Kukizaki, 2009b). A positive charge on the membrane surface can be induced by treating the membrane with amino trialkoxysilanes, such as (3-aminopropyl)-trimethoxysilane (APTMS) and (3-aminopropyl)-triethoxysilane (APTES) (Figure 3b). Amino trialkoxysilanes undergo hydrolysis in aqueous solution resulting in the formation of silanol groups, which can be then condensed with a silanol group on the SPG surface to form stable siloxane bonds ( $\mathrm{Si}-\mathrm{O}-\mathrm{Si})$.

\subsection{Microengineered membranes}

Microengineered membranes are microfiltration membranes with a controlled pore geometry and spatial arrangement manufactured by semiconductor fabrication methods (Brans et al., 
2006; Wagdare et al., 2010). Microengineered membranes are used in ME to achieve high transmembrane fluxes at low transmembrane pressures, due to its very low thickness, typically 1-100 $\mu \mathrm{m}$. These membranes have rectilinear pores with very low internal surface area, so they are less prone to fouling by emulsion ingredients than highly tortuous and porous SPG membranes. It is especially important in PME, where whole emulsion, rather than a pure dispersed phase, is pressed through the membrane. Typical microsieves used in ME are nickel microengineered membranes manufactured using UV-LIGA process (Nazir et al., 2011; Schadler and Windhab, 2006; Egidi et al., 2008), silicon nitride Aquamarijn ${ }^{\mathrm{TM}}$ microsieves fabricated by reactive ion etching (RIE) (van Rijn et al., 1997), stainless steel membranes fabricated by pulsed laser drilling (Dowding et al., 2001; Vladisavljević and Williams, 2006; Geerken et al., 2008) or end-milling (Kobayashi et al., 2008), and microchannel arrays fabricated in single crystal silicon by Deep Reactive Ion Etching (DRIE) (Kobayashi et al, 2003) or in PMMA by X-ray lithography and wet etching (Kobayashi et al., 2008b). The fabrication of microengineered membranes for ME is described by Vladisavljević et al. (2012).

\subsubsection{Surface modification of microengineered membranes}

Silicon membranes can be made hydrophilic via plasma oxidation in a plasma cleaner (Holzapfel et al., 2013). Silicon nitride and nickel membranes can be rendered hydrophilic by coating their surface with a thin layer of silicon oxide using plasma-enhanced chemical vapour deposition (PECVD) (Holzapfel et al., 2013). PECVD can also be used to decrease the

pore size, while keeping the circular pore shape (Schadler and Windhab, 2006). Nickel membrane can also be made hydrophilic by treatment with polyalkyleneoxide modified heptamethyltrisiloxane (Pan et al., 2012). Silicon nitride membranes can be hydrophobised by coating their surface with alkyltrichlorosilanes using chemical vapour deposition (Geerken et al., 2007).

\section{Emulsification using SPG membrane}

SPG membrane was widely used in DME (Vladisavljević et al., 2004; Vladisavljević and Schubert, 2002) and PME (Vladisavljević et al., 2004b; 2006; 2006b). Two main designs of membrane modules for DME are: (i) cross-flow systems with a tubular SPG membrane, 
which can be up to $500 \mathrm{~mm}$ long; (ii) SPG micro kits with a short SPG membrane tube (7-15 $\mathrm{mm}$ ) immersed in a stirred continuous phase.

\subsection{Cross-flow systems}

Cross-flow systems can be operated batchwise (with emulsion recirculation) or continuously (without any recirculation of the product emulsion). The volume fraction $\phi_{d}$ of the dispersed phase in a continuous cross-flow DME is given by:

$$
\phi_{d}=\frac{1}{\left(Q_{c} / Q_{d}\right)+1}
$$

The dispersed phase flow rate $Q_{d}$ must be much smaller than $Q_{c}$ to generate sufficient shear on the membrane surface. Therefore, in a continuous system $\phi_{d} \rightarrow 0$ and simple cross-flow DME must be operated batchwise to achieve a reasonably high $\phi_{d}$.

In a batch cross-flow DME system, a continuous phase liquid circulates from a storage tank through the bore of the membrane tube, and back to the storage tank (Figure 4). A dispersed phase-forming liquid stored in a pressure vessel is fed to the outside of the membrane tube and penetrates through the pores under the driving pressure of 1.1-5 times the capillary pressure (Vladisavljević and Schubert, 2003a). The system is operated until a desired volume fraction of the dispersed phase is reached in the product emulsion:

$$
\phi_{d}=\frac{Q_{d} t}{Q_{d} t+V_{c}}
$$

where $t$ is the operation time and $V_{c}$ is the volume of the continuous phase in the system. $\phi_{d}$ can be further increased up to 0.75 by vacuum evaporation of the formed emulsion (Matos et al., 2015). Recirculation of emulsion at high flow rate can lead to secondary droplet breakup. Two methods have been used to decrease flow rate of the continuous phase in the recirculation loop, while keeping the same shear stress on the membrane surface: insertion of static turbulence promoters into the membrane tube (Koris et al., 2011) and generation of back-and-forward pulsations in the cross flow (Piacentini et al., 2013b).

Transmembrane flux in cross-flow DME can be increased by 1-2 orders of magnitude (from $10^{-3}-10^{-1}$ to $10^{-1}-10^{0} \mathrm{~m}^{3} \mathrm{~m}^{-2} \mathrm{~h}^{-1}$ ) and the process can be run continuously by introducing the 
continuous phase into a SPG tube tangentially. It generates spiral streamlines in the axial direction known as the swirl flow that effectively remove droplets from the membrane surface at high transmembrane fluxes (Shimoda et al., 2011). In swirl-flow DME, $\phi_{d}$ can reach 0.4 in a single pass of the continuous phase through the membrane tube.

\subsection{SPG micro kits}

Cross-flow systems are easy to scale up and offer constant shear on the membrane surface which is independent of the volume of the continuous phase in the system. However, the volume of the continuous phase in the system must be at least several hundred millilitres. SPG micro kits shown in Figure 5 require only $8-50 \mathrm{~mL}$ of the continuous phase per single batch, which is useful for expensive clinical preparations (Higashi and Setoguchi, 2000). In the external pressure micro kit (Figure 5a), the continuous phase is placed in a stirred beaker and the dispersed phase is injected through membrane tube from outside to inside. Membrane tube serves as a draft tube, which results in more effective circulation of the continuous phase than in the internal pressure micro kit shown in Figure 5c.

A typical SPG membrane rig for PME is shown in Figure 5b. A pressurised pre-mix from a pressure vessel is pressed through the membrane tube from outside to inside under the pressure difference ranging from several bars (for a 10- $\mu \mathrm{m}$ membrane) to more than $10 \mathrm{bar}$ (for 1- $\mu \mathrm{m}$ membrane) and up to 50 bar for the membrane with sub-micron pore sizes. The product emulsion flows from the membrane tube under gravity and is collected in a beaker placed beneath the module. To further reduce the droplet size and improve the droplet size uniformity, the product emulsion can be pressed repeatedly through the same membrane (Vladisavljević et al., 2004b; 2006; 2006b). Repeated membrane homogenisation was invented by Olson et al. (1979) and used for homogenisation of lipid vesicles by track-etch polycarbonate filters.

\section{Emulsification using microengineered membranes}

Microengineered membranes have been widely used in ME in the past two decades. They can be fabricated with circular pores (Kosvintsev et al., 2005), slotted (rectangular and squared) pores (Kobayashi et al., 2005; Nazir et al., 2013), asymmetric slotted/circular pores 
(Kobayashi et al., 2005b), and micro-chimneys (Geerken, 2006). Rectangular pores with an aspect ratio of at least 3 enable a spontaneous drop generation due to a Laplace instability and are more convenient in DME than square or circular pores (Kobayashi et al., 2004; 2009; van Dijke et al., 2010). Asymmetric pores have circular channels on the upstream (bottom) side of the membrane and rectangular channels on the downstream (top) side (Kobayashi et al., 2005b; Vladisavljević et al., 2008; 2011). Asymmetric geometry is useful when the dispersed phase viscosity is low (1 mPa s or less), e.g. when the dispersed phase is water or volatile hydrocarbons (Kobayashi et al., 2005; 2009b).

A shear on the membrane surface can be generated using paddle stirrer placed above the membrane surface, like in the Micropore Dispersion Cell (Kosvintsev et al., 2005), but other ME systems with microengineered membrane have been also developed, such as cross flow (Abrahamse et al., 2002), pulsed cross flow (Holdich et al., 2013), rotating membrane (Vladisavljević and Williams, 2006; Aryanti et al., 2006) and oscillating membrane (Holdich et al., 2010). In an oscillating ME system, tubular membrane can oscillate tangentially clockwise and counter-clockwise (Silva et al. 2015) or radially upward and downward (Holdich et al., 2010), with frequencies from 10 to $90 \mathrm{~Hz}$.

In a continuous DME device, cross flow velocity must be very low in order to achieve reasonably high dispersed phase content, which means that shear on the membrane surface must be controlled by alternative methods. The surface shear can be decoupled from the cross flow by rotating or vibrating the membrane within a static continuous phase (Holdich et al., 2010; Zeng et al., 2013; Gomaa et al., 2014; Vladisavljević and Williams, 2006) or introducing forward and backward flow pulsations in cross flow (Holdich et al., 2013). The advantages of pulsed cross flow over rotating or vibrating membrane are: (i) liquid pulsations require less energy than membrane oscillations or rotations because liquids are less dense than solids and have a lower inertia; (ii) the energy consumption to maintain pulsed flow is independent on membrane area, whereas energy input to maintain membrane vibrations or rotations is in proportion with membrane dimensions, and (iii) pulsed cross flow can be extended to a baffled reactor, connected in series to the membrane module, to achieve simultaneous drop generation and reaction in the produced emulsion (Piacentini et al., 2013). 
PME was successfully carried out using microengineered nickel membranes with rectangular (Nazir et al., 2011), squared (Nazir et al., 2013) and circular (Santos et al., 2015) pores. The experimental set-up is very similar to that for SPG PME shown in Figure 5b.

\section{Control over droplet size in DME}

The droplet size distribution in DME depends on numerous factors, that can be divided into membrane parameters (surface wettability and charge, porosity, pore size distribution, pore morphology and spatial arrangement), formulation parameters (viscosity of the dispersed and continuous phase, the type and concentration of surfactants and additives) and process parameters (shear stress on the membrane surface and transmembrane flux) (Joscelyne and Trägårdh, 2000). The analytical and computational models for prediction of droplet size in DME can be found elsewhere (Spyropoulos et al., 2014; Rayner et al., 2004).

\subsection{Effect of transmembrane pressure and flux}

The minimum transmembrane pressure for driving the dispersed phase through the pores is known as the capillary pressure, $P_{c a p}$, and is given by the Young-Laplace equation:

$$
P_{\text {cap }}=\frac{4 \gamma_{w o} \cos \theta}{d_{p}}
$$

where $\gamma_{w o}$ is the equilibrium interfacial tension between the dispersed and continuous phase, $\theta$ is the contact angle formed by the dispersed phase at the three-phase boundary where the continuous phase, the dispersed phase and the membrane meet together (Figure 6). A hydrophilic membrane $\left(\theta<90^{\circ}\right)$ is used for production of $\mathrm{O} / \mathrm{W}$ emulsion, and thus $P_{\text {cap }}>0$ and $P_{o}>P_{a q}$, i.e. at zero flux the oil phase has a higher pressure than the aqueous phase. A hydrophobic membrane $\left(\theta>90^{\circ}\right)$ is used for production of W/O emulsion, and thus $P_{\text {cap }}<0$ and $P_{o}<P_{a q}$, i.e. the aqueous phase pressure should be higher than the oil phase pressure by at least $P_{\text {cap }}$ to drive the water phase through the membrane.

Two mechanisms of drop formation are observed in DME: (a) shear-controlled detachment as a result of shear stress on the membrane surface and (b) spontaneous droplet detachment (Sugiura et al., 2002). A shear-controlled detachment dominates for membranes with circular 
pores (Kosvintsev et al., 2005), while spontaneous detachment occurs for membranes with pronounced non-circular pores, such as SPG membrane and microengineered membranes with slotted pores. In a shear-controlled droplet formation process, bigger droplets are formed at higher transmembrane flux (line $\mathbf{1}$ in Figure 7), which can be explained by the fact that the detachment of a droplet from the membrane surface is not instantaneous but requires a finite time, the necking time. During the necking time an additional amount of the dispersed phase will flow into a forming droplet causing the droplet size to increase in proportion to the flow rate of the dispersed phase (van der Graaf et al., 2006). At high fluxes, the push-off force due to droplet-droplet interactions on the membrane surface assists in the droplet detachment process, causing a plateau region to occur on a $d_{d}$ vs. $J$ plot at high fluxes (Egidi et al., 2009).

Spontaneous droplet detachment can take place under two droplet formation regimes determined by the capillary number of the dispersed phase: $C a=U_{d} \eta_{d} / \gamma_{w o}$, where $U_{d}$ is the velocity of the dispersed phase within a pore and $\eta_{d}$ is the viscosity of the dispersed phase. The dripping regime prevails at low fluxes $\left(C a<C a_{c r}\right)$. In this regime, the interfacial tension dominates inertial and drag forces (Sugiura et al., 2002) and the droplet size is almost independent on transmembrane flux or shear stress (line 2 in Figure 7). At high transmembrane fluxes and $U_{d}$ values $\left(C a>C a_{c r}\right)$, droplets grow to a large size $\left(d_{d} / d_{p}>10\right.$ ) before being detached from the membrane surface, which is known as the continuous outflow regime (Kobayashi et al., 2003). In this regime, the inertial force dominates the interfacial tension force and the droplet size strongly depends on transmembrane flux. The transmembrane flux at which the transition occurs is independent on the pore size (Kobayashi et al., 2011) and increases with decreasing the viscosity of the dispersed phase (Vladisavljević et al., 2011). At high shear on the membrane surface and high dispersed phase flow rates, a growing droplet is significantly distorted in the direction of shear force and forms a neck parallel to the membrane surface, which is stretched until if collapses and releases a droplet (Van der Graaf et al., 2005), which is known as the jetting regime. DME must be conducted in the dripping regime, since the emulsions produced in the continuous outflow and jetting regimes are polydisperse, due to random nature of the pinch-off process. The transition from dripping to continuous outflow/jetting does not occur simultaneously for all the pores, leading to bimodal particle size distribution of the droplets as a result of droplets being formed under different regimes at the same time. 


\subsection{Effect of pore size and shear stress on the membrane surface}

For spontaneous droplet formation, a linear correlation between the mean droplet size and the mean pore size exists in the dripping regime: $d_{d}=K^{\prime} d_{p}$ (line 3 in Figure 7 ), where $K^{\prime}=$ 2.8-3.5 for SPG membrane (Kukizaki and Goto, 2009; 2007c; Nakashima et al., 1991; Vladisavljević et al., 2006). Even in the absence of any shear on the membrane surface, $K^{\prime}$ was found to be 3.3 for $1 \%$ Tween- 80 stabilised O/W emulsions produced using SPG membrane (Kukizaki and Goto, 2009). For slotted pores: $d_{d}=K_{1}{ }^{\prime} D_{h, p}$, where $D_{h, p}$ is the hydraulic pore diameter and $K_{1}{ }^{\prime} \approx 3$.

In a shear-controlled droplet formation process at low transmembrane flux, the mean droplet size is determined by the balance between the shear force exerted on the forming droplet by the continuous phase, $F_{d}$ and the capillary force, $F_{c a}$ (Kosvintsev et al., 2005):

$$
\begin{aligned}
& F_{c a}=\pi d_{p} \gamma_{w o} \\
& F_{d}=9 \pi \tau_{w} d_{d} \sqrt{\left(d_{d} / 2\right)^{2}-r_{p}^{2}}
\end{aligned}
$$

where $r_{p}$ is the pore radius and $\tau_{w}$ is the shear stress on the membrane surface. The droplet pinch-off occurs when $F_{c a}=F_{d}$ :

$$
d_{d}=\frac{\sqrt{18 \tau_{w}^{2} r_{p}^{2}+2 \sqrt{81 \tau_{w}^{4} r_{p}^{4}+4 r_{p}^{2} \tau_{w}^{2} \gamma^{2}}}}{3 \tau_{w}}
$$

The mean drop diameter decreases with increasing shear stress on the membrane surface and tends to the pore diameter at very high shear stresses.

As a conclusion, uniform droplets can be produced only in dripping regime, which prevails at low transmembrane fluxes. For droplet formation by spontaneous droplet detachment, the droplet size in the dripping regime is proportional to the pore size. For shear-controlled droplet formation, the droplet size is no longer proportional to the pore size and is generally determined by the balance between the shear force acting on the growing droplet, inertial force originating from the dispersed phase flow and the interfacial tension force. In this case, the size of resultant droplets increases with increasing transmembrane flux and pore size and decreases with increasing shear stress on the membrane surface and interfacial tension. 


\subsection{Effect of surfactant}

The effect of kinetics of adsorption of surfactant at oil-aqueous interface during DME on the droplet size has been investigated by Schröder et al. (1998), Van der Graaf et al. (2004), and Rayner et al. (2005). The faster the surfactant molecules adsorb to the newly formed interface, the smaller the droplet size becomes. Surfactant molecules must not bind to the membrane surface by Van der Waals or electrostatic interactions, because the dispersed phase will spread over the membrane surface, which will lead to uncontrolled droplet generation. For negatively charged SPG membrane, it means that cationic surfactants, e.g. alkyltrimethylammonium salts such as cetyltrimethyl-ammonium bromide (CTAB) must not be used, since they lead to polydispersed O/W emulsions with $d_{d} / d_{p}>20$ (Nakashima et al., 1993). The use of zwitterionic surfactants must also be avoided, even when they carry a net negative charge (Surh et al., 2008). To produce cationic droplets using SPG membrane, the membrane must be pre-treated with amino trialkoxysilanes to become positively charged (Figure 3b) or the charge of anionic droplets must be altered after ME by displacing anionic surfactants with cationic ones (Vladisavljević and McClements, 2010).

\section{Control over droplet size in PME}

The mean droplet size in PME depends on the pore size of the membrane, transmembrane flux, number of passes through the membrane, viscosity of the continuous and dispersed phase and interfacial tension (Nazir et al., 2010). The mean droplet size is a non-linear function of the mean pore size (line 5 in Figure 7):

$d_{d}=K^{\prime \prime}\left(d_{p}\right)^{n}$

where $n<1$. The droplet to pore size ratio $\left(d_{d} / d_{p}\right)$ decreases with the mean pore size and ranges from 1 to 1.5 for SPG membrane with $d_{p}=5-20 \mu \mathrm{m}$ for the wall shear stress inside the pores of 200 Pa (Vladisavljević et al., 2006). The critical pressure in PME is given by (Park et al., 2001):

$$
P_{\text {cap }}=\frac{\gamma\left[2+2 a^{6} / \sqrt{2 a^{6}-1} \times \arccos \left(1 / a^{3}\right)-4 a^{2}\right]}{a+\sqrt{a^{2}-1}}
$$


where $a=d_{p m} / d_{p}$ and $d_{p m}$ is the mean droplet size in a pre-mix. If $a » 1$, the capillary pressure is given by Eq. (6). In PME, the optimum transmembrane pressure is 10-50 times larger than $P_{\text {cap }}$ (Vladisavljević et al., 2004b). The mean droplet size decreases with increasing the wall shear stress inside the pores, given by:

$$
\tau_{w, p}=8 \eta_{e} J \xi /\left(\varepsilon d_{p}\right)
$$

where $\eta_{e}$ is the viscosity of emulsion inside the pores. In PME, smaller droplets are produced at higher transmembrane fluxes, due to higher shear stresses generated inside the pores, as shown by line 4 in Figure 7. The droplet size can be additionally reduced by passing emulsion several times through the membrane (Vladisavljević et al., 2004b; Laouini et al., 2014).

\section{Integration of membrane emulsification and solid/semi-solid particle fabrication}

From the early 1990s, membrane emulsification was used for the preparation of O/W or W/O emulsions with a narrow particle size distribution and controlled mean particle size (Nakashima et al., 1991). Membrane emulsification technology has since been extended to the production of multiple emulsions, such as solid-in-oil-in-water (S/O/W) (Kukizaki, 2009c), oil-in-water-in-oil (O/W/O) (Wei et al., 2013; Cho et al., 2005) and water-in-oil-in-water (W/O/W) (Surh et al., 2007), nano- and micro-emulsions (Koga et al., 2010; Oh et al., 2011; Laouini et al., 2012; Choi et al., 2012; Pradhan et al., 2013; Oh et al., 2013), multilayer emulsions (Vladisavljević and McClements, 2010; Gudipati et al., 2010; Nazir et al., 2012), microbubbles (Kukizaki and Goto, 2007), nanobubbles (Kukizaki and Goto, 2006), microand nano-particles (Vladisavljević and Williams, 2005; 2010), and nanovesicles (liposomes and niosomes) (Hwang et al., 2011; Pham et al., 2012). The examples of particles fabricated by solidification of droplets produced using SPG membrane are given in Table 4.

\subsection{Integration of membrane emulsification and crosslinking of gel-forming polymers}

Hydrogels are three-dimensional networks composed of cross-linked hydrophilic polymers. Hydrogels are insoluble in water but can absorb and hold large amount of water due to their hydrophilic character (Hoare and Kohane, 2008). Microgels are spherical hydrogel microparticles which can be produced by injecting an aqueous solution of gel forming monomers or pre-formed polymers through hydrophobic membrane (Mi et al., 2015). A 3D network can be formed by chemical crosslinking of monomers through condensation 
polymerisation (e.g. polyamide) and free radical polymerisation (e.g. polyacrylate), but physical crosslinking is more common and can involve heating (heat-set gels such as whey protein gel), cooling (cold-setting gels such as agarose and gelatine) or electrostatic interaction (ionotropic gelation). In ionotropic gelation, gel-forming polymer must contain charged functional groups, such as amino groups of chitosan or carboxylic group of alginate, which can interact with oppositely charged divalent or polyvalent crosslinkers. The main strategies used for physical crosslinking of droplets produced by ME are shown in Figure 8.

\subsubsection{Internal gelation}

In the internal gelation method (Figure 8a), the dispersed phase contains a gel-forming polymer and a crosslinking agent in a nondissociated (inactive) form (e.g. $\mathrm{CaCO}_{3}$ particles instead of $\mathrm{Ca}^{2+}$ ). Solid beads are formed by adding a species (e.g. $\mathrm{H}^{+}$) that diffuses into the droplets and triggers the release of a crosslinking agent in its active form. In the case of $\mathrm{CaCO}_{3} / \mathrm{H}^{+} /$alginate system, the released $\mathrm{Ca}^{2+}$ ions bind to the L-guluronate residues of alginate, crosslinking the polymer and causing the droplets to gel. The $\mathrm{H}^{+}$ions can be added by dropping glacial acetic acid into the resultant W/O emulsion under stirring, as shown in Table 5A. The size of $\mathrm{CaCO}_{3}$ particles should be about 10 times smaller than the pore size of the membrane to prevent pore blockage. A $10-\mu \mathrm{m}$ microengineered membrane was blocked when the size of $\mathrm{CaCO}_{3}$ particles suspended in the oil phase phase was $2.3 \mu \mathrm{m}$, but no blockage was observed when a 20- $\mu \mathrm{m}$ membrane was used (Hanga and Holdich, 2014). For SPG membrane, blockage is more likely due to tortuous and interconnected pore structure. Another disadvantage of internal gelation is that $\mathrm{Ca}^{2+}$ could be non-uniformly distributed in the dispersed phase, due to grains of nondissolved $\mathrm{CaCO}_{3}$ in the beads (Ogończyk et al., 2011).

Gelation of alginate with $\mathrm{Ca}^{2+}$ is a reversible process and the Ca-alginate beads can be solubilised in an aqueous solution containing monovalent ions due to exchange of $\mathrm{Ca}^{2+}$ with non-cross-linkable monovalent ions. Irreversible alginate gel can be synthesised using alginate with phenol moieties, which can be crosslinked via oxidative C-C and C-O coupling with hydrogen peroxide (Sakai et al., 2007).

\subsubsection{External gelation}

In the external gelation method (Figure 8b and Table 5B), the aqueous phase droplets contain only a polymer or a mixture of polymers and the crosslinking agent is added once the W/O emulsion is formed. The dispersed phase also contains encapsulants, such as microbial cells, 
if they need to be entrapped into a hydrogel matrix (Choi et al., 2014). Typical crosslinking agents are $\mathrm{Ca}^{2+}$ for alginate beads, glutaraldehyde (GA) and tripolyphosphate (TPP) for chitosan beads and GA for haemoglobin-albumin microspheres. In the case of calcium alginate and chitosan/TPP beads, cross-linking involves electrostatic interactions, but in the case of GA cross-linked polymers, the gelling occurs due to covalent bonding between amino groups of the polymer and aldehyde groups of GA and formation of a Schiff-base type bond. In order to maintain the original droplet size distribution after cross-linking, toluene saturated with GA was used for cross-linking reaction, rather than aqueous GA solution (Wang et al., 2005). The oil phase used in the external gelation was usually a mixture of oil-soluble surfactant and low-viscosity organic solvent, such as isooctane, kerosene or 7:5 (v/v) paraffin/petroleum ether mixture.

\subsubsection{Gel formation by cooling}

Polymers like gelatine and agarose can form hydrogels upon cooling from their aqueous solutions. The gel formation is due to coil-to-helix transition: coil $\rightarrow$ helix $\rightarrow$ gel (Viebke et al., 1994). The first step in this process is the transition of polymer from a random coil to helix confirmation and the second step is association and branching of these helices into a 3D network. This method was used to produce agarose beads by emulsifying agarose solution using SPG membrane at $55-70{ }^{\circ} \mathrm{C}$, followed by cooling the resultant $\mathrm{W} / \mathrm{O}$ emulsion (Figure 8c and Table 5C). In ME using SPG membrane, the mean size of agarose beads was found to be proportional to the mean pore size of SPG membrane:

$$
d_{\text {bead }}=n d_{p}
$$

In DME, $n=3$ for $d_{p}=5-20 \mu \mathrm{m}$ (Zhou et al., 2007) and $n=3.6-3.7$ for $d_{p}=23-30 \mu \mathrm{m}$ (Zhao et al., 2014). In PME, $n=0.49$ for $d_{p}=6-19 \mu \mathrm{m}$ (Zhou et al., 2009). No difference in size was found between agarose droplets and produced beads. The droplets were much more uniform when low-viscosity mixture of liquid paraffin and petroleum ether oil (7:5 v/v) was used as the continuous phase liquid than high-viscosity oils such as pure paraffin oil and vegetable oil (Zhou et al., 2007).

\subsubsection{Gel formation by droplet merging (coalescence)}

In this method (Figure 8d), microgels are formed by mixing two W/O emulsions: emulsion 1 containing droplets of the polymer solution and emulsion 2 containing droplets of the crosslinking agent. The crosslinking mechanism involves merging two droplets (1 and 2) and 
mixing of their contents, which triggers a crosslinking reaction within the fused droplet. However, a stochastic nature of the coalescence process inevitably leads to the formation of polydisperse beads even if the original emulsions are monodisperse (Sugiura et al., 2005). Alginate beads were created by mixing together alginate and $\mathrm{CaCl}_{2}$ emulsion droplets and chitosan beads were obtained by fusing acidic chitosan drops and sodium hydroxide drops. In the latter case, the gelling was a result of precipitation of chitosan in a basic environment formed within the merged droplets (Table 5D). Emulsion 1 must be prepared by ME and emulsion 2 can be prepared by ultrasonication or ME. Hybrid chitosan/alginate beads were formed by merging a chitosan and alginate droplet and subsequent electrostatic interaction between a polycation (chitosan) and polyanion (alginate) within the combined droplet.

Hollow chitosan beads were fabricated using the following procedure (Figure 8 e): (i) alginate beads were prepared by mixing together two W/O emulsions containing sodium alginate and $\mathrm{CaCl}_{2}$ droplets; (ii) the produced alginate beads were coated with chitosan solution by mixing the resultant alginate beads with a W/O emulsion containing chitosan droplets; (iii) chitosan layer deposited onto the surface of alginate beads was crosslinked by mixing chitosan-coated alginate beads with the $\mathrm{W} / \mathrm{O}$ emulsion containing tripolyphosphate in the aqueous phase droplets. Polyphosphate has twofold action: it is a crosslinker for chitosan and $\mathrm{Ca}^{2+}$ catcher for calcium alginate gel, which results in the dissolution of alginate core and formation of hollow chitosan particles.

\subsubsection{Gel formation by heating}

Chitosan beads were fabricated by reverse thermal gelation of the droplets containing quaternized chitosan and glycerol-2-phosphate (GP) (Table 5E). The gelation occurred at $\sim 37^{\circ} \mathrm{C}$ due to hydrophobic interactions between chitosan chains that are not possible at room temperature due to protective hydration of the chains in the presence of GP (Wu et al., 2008).

W/O/W emulsions containing gelled water droplets were obtained by a three-stage process shown in Figure 9: (i) formation of W/O emulsion with submicron aqueous droplets by highpressure homogenisation; (ii) thermal gelation of whey proteins within the aqueous droplets at $80^{\circ} \mathrm{C}$; (iii) preparation of $\mathrm{W} / \mathrm{O} / \mathrm{W}$ emulsion by mixing the $\mathrm{W} / \mathrm{O}$ emulsion with gelled water droplets and an external aqueous phase and homogenising this course emulsion by PME (Surh et al., 2007). The thermal gelation of whey protein isolate is a two-step process consisting of unfolding protein molecules and covalent cross-linking of unfolded protein chains, due to 
formation of disulphide (S-S) bonds. The prepared W/O/W emulsion has improved stability and controlled release properties.

\subsection{Integration of membrane emulsification and melt solidification}

Membrane emulsification / melt solidification process involves ME above the melting point $T_{m}$ of the dispersed phase followed by cooling the emulsion below the melting point. This approach was used for fabrication of solid lipid particles for oral drug delivery (Kukizaki, 2009c), low-melting-point metal particles for soldering microcomponents in microelectronics (Torigoe et al., 2011) and thermochromic liquid crystal particles for digital particle tracking thermography/velocimetry (Segura et al., 2013). Solid lipid microparticles are particles formed from lipids that are solid at room temperature, such as saturated fatty acids (palmitic acid, stearic acid and behenic acid) and mono-, di-, and triesters of glycerol and polyethylene glycol (PEG) (Table 6). The melting point of these lipids lies between 44 and $65{ }^{\circ} \mathrm{C}$ and $\mathrm{ME}$ must be carried out at the temperature which is at least $5^{\circ} \mathrm{C}$ higher than the melting point of the lipid to prevent membrane fouling.

Three different template emulsions used for fabrication of solid lipid particles using ME are $\mathrm{O} / \mathrm{W}, \mathrm{W} / \mathrm{O} / \mathrm{W}$ and S/O/W (Table 6). The O/W melt dispersion method was used to produce solid lipid microcarriers for encapsulation of lipophilic active ingredients (LAIs), such as vitamin E (Laouini et al., 2014). LAI is first dissolved in a hot melted lipid and the solution is premixed with a hot aqueous surfactant solution and passed through the membrane multiple times (Figure 10). The produced O/W emulsion is rapidly cooled to the room temperature to solidify the dispersed lipid phase.

The W/O/W melt dispersion method was used to produce solid lipid microcarriers for encapsulation of hydrophilic active ingredients (HAIs), such as vitamin B12. Following oral administration, HAI gradually releases from the carriers in the small intestine due to degradation of the solid lipid matrix by lipase. Kukizaki and Goto (2007c) developed a twostage DME process to prepare first a W/O and then W/O/W emulsion using SPG membrane with a pore size of 0.3 and less than $1 \mu \mathrm{m}$, respectively (Figure 11). The droplet to pore size ratio was 3.3-3.4 in both cases. Finally, the W/O/W emulsion was cooled down to crystallise 
the lipid phase and convert the W/O/W emulsion into W/S/W dispersion. W/S microparticles were obtained by filtration of the W/S/W dispersion.

W/S microparticles contain a considerable amount of water (up to $40 \mathrm{wt} \%$ ), because water droplets within the carrier remain intact after crystallisation of the oil phase. To improve microbiological stability of the solid lipid particles, the inner water was removed from the $\mathrm{W} / \mathrm{O}$ emulsion by vacuum evaporation at $60^{\circ} \mathrm{C}$ to obtain a dispersion of HAI nanoparticles in the lipid melt (Figure 12) (Kukizaki and Goto, 2009). The presence of PGPR in the oil phase inhibited droplet coalescence and particle aggregation during vacuum dehydration, so the final size of PGPR-coated HAI nanoparticles in the S/O dispersion was $130 \mathrm{~nm}$. This S/O dispersion was then dispersed in the aqueous surfactant solution by PME to form a hot S/O/W emulsion. The ratio of the mean size of microcarriers to the mean pore size was 1-1.5 (Kukizaki and Goto, 2009). Finally, the S/O/W emulsion was cooled to room temperature to obtain solid lipid microparticles with embedded nanoparticles of HAI.

\subsection{Integration of membrane emulsification and spray drying}

Ramakrishnan et al. (2013) produced fish oil microcapsules coated with maltodextrin by spray drying fish oil-in-water emulsions. Fish O/W emulsions stabilised with $2 \mathrm{wt} \%$ Tween 20, 1-10 wt\% WPI or 1-10 wt\% WPH were prepared by PME using nylon or nitrocellulose mixed esters (MCE) membrane. The emulsions were mixed with a wall material (maltodextrin) in 1:1 or 1:3 (oil to maltodextrin) mass ratio and spray dried. The oil encapsulation efficiency was higher when the emulsion was prepared by PME than using Ultra-Turrax $^{\circledR}$. Berendsen et al. (2015) prepared microcapsules containing procyanidin-rich extracts from W/O/W emulsions stabilised with WPI-polysaccharide soluble complexes using PME with SPG membrane. Before spray drying, W/O/W emulsions were mixed with maltodextrin in 1:3 (oil to maltodextrin) ratio. The highest encapsulation efficiency was achieved using multiple emulsion droplets stabilised with WPI-CMC complex.

\subsection{Integration of membrane emulsification and organic solvent removal from droplets}

Membrane emulsification was combined with solvent removal to produce synthetic biodegradable polymeric particles (Ito et al., 2011), nanoclusters (Chang and Hatton, 2012), 
liquid-core/polymer-shell particles (Sawalha et al., 2008), Janus particles (Chang and Hatton, 2012), hemispherical particles (Yamashita et al., 2012), and quantum dot barcodes (Wang et al., 2013). The strategy used for solvent removal from the droplets was evaporation at room temperature, fast diffusion into large amount of water (Ito et al., 2011; Imbrogno et al., 2014; 2015) and pervaporation through polypropylene hollow fibers (Chang and Hatton, 2012).

\subsubsection{Solvent removal from single emulsions}

\section{A. Synthetic biodegradable polymeric particles loaded with hydrophobic actives}

Coherent particles were prepared by emulsifying an organic polymer solution in an aqueous surfactant solution by ME, followed by organic solvent removal from the oil phase (Figure 13a). Typical polymers used in the process are polylactide (PLA), poly(lactide-co-glycolic acid) (PLGA) and polylactide-co-poly(ethylene glycol) (PELA) and a volatile organic solvent was mainly ethyl acetate or dichloromethane (DCM) (Table 7A). In the absence of swelling, the diameter $d_{\text {part }}$ of a particle formed after complete solvent removal from a droplet with an initial diameter of $d_{d}$ can be calculated from the equation (Vladisavljević et al., 2012b):

$$
d_{\text {part }}=\left[\left(x_{p o l} /\left(1-\varepsilon_{\text {part }}\right)\right)\left(\rho_{d} / \rho_{\text {pol }}\right)\right]^{1 / 3} d_{d}
$$

where $x_{p o l}$ is the mass fraction of polymer in the dispersed phase, $\rho_{p o l}$ is the polymer density, $\varepsilon_{\text {part }}$ is the particle porosity, and $\rho_{d}$ is the density of the dispersed phase. In repeated premix SPG ME, the particle size can be more than 10 times smaller than the membrane pore size (Table 7A), whereas in direct SPG ME, the particle size is typically larger than the membrane pore size. In order to produce PLGA particles with 100\% yield by PME, the minimum pore size of SPG membrane has to be $0.5 \mu \mathrm{m}$ (Ito et al., 2011). When the pore size of SPG membrane was reduced from 0.5 to $0.26 \mu \mathrm{m}$, no change in particle size was observed, but the yield of PLGA particles was very low due to pore clogging by the polymer (Ito et al., 2011).

Drug-loaded biodegradable particles were prepared by adding hydrophobic drugs such as rifampicin (Doan et al., 2011), haloperidol (Meyer et al., 2010) and paclitaxel (Wang et al., 2015) to the oil phase prior to ME. The drug loading, encapsulation efficiency and release profile are dependent on the polymer hydrophobicity. The highest loading and encapsulation efficiency of paclitaxel (PTX) was achieved with PLGA (5.2\% and 70.5\% respectively), followed by PLA (4.3\% and 64.3\%) and PELA (3.4\%, 56.7\%), which was attributed to the highest hydrophilicity of PLGA (Wang et al., 2015). During formation of PLGA particles, 
PTX precipitates faster than PLGA forming nanoparticles that migrate towards the interior of the particle due to their high hydrophobicity. With further solvent evaporation, PLGA precipitates and forms a protective polymer layer around drug nanoparticles. On the other hand, PLA precipitates faster than PTX and the formed polymer network prevents the migration of PTX within the particle. As a result, the drug was uniformly distributed within PLA particles and less effectively encapsulated (Wang et al., 2015).

The encapsulation efficiency of rifampicin in PLGA particles produced by DME was 50-67 \% regardless of the particle size (Ito and Makino, 2004). For parenteral depot systems, the optimum particle diameter is 10-50 $\mu \mathrm{m}$ (Veldhuis et al., 2009). The particles smaller than $10 \mu \mathrm{m}$ can easily be cleared from the injection site by phagocytosis and the particles larger than $50 \mu \mathrm{m}$ require needles larger than 27 gauge, which may cause significant patient discomfort. PLGA particles within that size range can be produced by DME using both SPG and microsieve membranes (Gasparini et al., 2008; Veldhuis et al., 2009). The particle size of dry powder aerosols for pulmonary drug delivery should be less than $5 \mu \mathrm{m}$, and the particle size less than $2 \mu \mathrm{m}$ is preferable for alveolar deposition (Bao and Zhao, 2010). PLGA particles smaller than $0.2 \mu \mathrm{m}$ can be produced by PME with SPG membrane (Ito et al., 2011).

\section{B. Liquid-core/polymer-shell particles}

Liquid-core/polymer-shell particles were produced by combining PME to form O/W emulsion and solvent evaporation to induce phase separation within the oil droplets and formation of core/shell structure (Sawalha et al., 2008). As shown in Figure 13b, internal phase separation starts with the removal of volatile solvent from the drops containing a mixture of polymer, such as PLA, a volatile water-immiscible good solvent for the polymer such as DCM, and non-volatile water-immiscible non-solvent ('oil' e.g., a C6-C20 hydrocarbon). As solvent gradually evaporates, the drop shrinks and becomes increasingly more enriched in polymer and non-solvent. When the drop composition reaches the binodal boundary, the phase separation occurs within the drop ('the internal phase separation'), leading to the formation of tiny droplets of polymer-enriched phase (which are rich in solvent and polymer) dispersed in a polymer-poor phase (mainly consisting of non-solvent). As the polymer is more hydrophilic than the non-solvent, polymer-enriched droplets migrate within the drop to the interface with the aqueous phase, where they fuse and spread to engulf the oil droplet (Loxley and Vincent, 1998). Further solvent removal causes the polymer to precipitate in the shell, forming a 
coherent solid envelope around the oil. This method was used to prepare dodecanecore/PLLA-shell particles using a mixture of PLLA, DCM and dodecane as a dispersed phase (Sawalha et al., 2008) and hexadecane-core/Eudragit ${ }^{\circledR}$-shell particles starting from the droplets composed of Eudragit FS 30D, hexadecane, and DCM (Table 7B) (Wagdare, 2011).

The presence of 25-30 wt\% alcohol in the continuous phase during evaporation of DCM increases the rate of solvent removal from the droplets, as DCM is more soluble in alcoholwater mixtures than in pure water (Sawalha et al., 2008). As a result, the polymer solidifies more quickly and smaller and more uniform PLLA particles can be obtained. At higher alcohol concentrations in the continuous phase $(>50 \%$ for methanol, $>45 \%$ for ethanol and $>35 \%$ for 2-propanol), DCM is completely miscible in the continuous phase, which results in nanoprecipitation of PLLA after mixing the two phases and formation of PLLA nanoparticles.

\section{Janus particles and non-spherical particles}

Polymeric Janus particles were formed using the method shown in Figure 13c, where an oil phase containing a 1:1 mixture of polymer 1 and polymer 2 (PMMA and P(St-co-BIEM) or PS and P(MMA-co-CMS), respectively) dissolved in toluene was emulsified using SPG membrane (Table 7C), which was then followed by solvent evaporation (Yamashita et al., 2008; Ahmad et al., 2008). Bifacial morphology is favoured when $S_{1}<0, S_{2}<0$, and $S_{3}<0$, where $S_{1}, S_{2}$, and $S_{3}$ are the spreading coefficients for polymer 1 rich phase, polymer 2 rich phase, and continuous phase, respectively. In the absence of interactions between the phases, spreading coefficients are given by:

$$
\begin{aligned}
& S_{1}=\gamma_{23}-\left(\gamma_{12}+\gamma_{13}\right) \\
& S_{2}=\gamma_{13}-\left(\gamma_{12}+\gamma_{23}\right) \\
& S_{3}=\gamma_{12}-\left(\gamma_{13}+\gamma_{23}\right)
\end{aligned}
$$

When $S_{1}<0, S_{2}>0$, and $S_{3}<0$, the particles adopt a core/shell morphology with polymer 1 as a core and polymer 2 as a shell, and when $S_{1}>0, S_{2}<0$, and $S_{3}<0$, polymer 1 will appear as a core and polymer 2 as a shell.

Hemispherical microparticles were produced by the cleavage of Janus PMMA/P(St-co-BIEM) particles in $9 / 1(\mathrm{v} / \mathrm{v})$ acetone/water solution for $5 \mathrm{~s}$. The particle cleavage is a result of stress which occurs at the boundary between the two polymers due to uneven swelling of PMMA and $\mathrm{P}(\mathrm{St}-\mathrm{co}-\mathrm{BIEM})$ in the presence of acetone (Yamashita et al., 2008). In addition, the 
polymer swelling weakens cohesive intermolecular forces between the two polymers due to reduced entanglement between PMMA and P(St-co-BIEM) chains at the interface. When the interfacial stresses caused by uneven swelling of the two hemispheres overcome cohesive forces between them, Janus particles split into two hemispheres, as shown in Figure 13c.

“Mushroom-like” PMMA/P(St-co-BIEM)-g-PDM Janus particles with pH-responsive PDM half-shells were fabricated by surface-initiated atom transfer radical polymerization (ATPR) of 2-(dimethylamino)ethylmethacrylate (DM) using spherical PMMA/P(St-co-BIEM) Janus particles with bromine end groups at one side of the surface as macroinitiator (Tanaka et al., 2010) (Figure 13c).

\section{Composite core/shell particles}

Composite PLGA particles coated with $50 \mathrm{~nm}$-silica nanoparticles were fabricated by DME combined with solvent evaporation and layer-by-layer (LbL) electrostatic deposition (Ito et al., 2010). Due to the presence of terminal carboxyl groups on their surface, PLGA particles are negatively charged in aqueous solutions and can be coated with positively charged polymers and particles. The LbL electrostatic deposition involved adsorption of polycation poly(allylamine hydrochloride) (PAH) onto the surface of negatively charged PLGA particles, followed by deposition of negatively charged silica nanoparticles on the surface of positively charged PAH/PLGA composite particles (Figure 13d).

Composite PLGA particles coated with poly(ethyl 2-cyanoacrylate) (PE2CA) were prepared by DME combined with interfacial polymerisation and solvent evaporation (Lee et al., 2009). The dispersed phase composed of PLGA, ethyl 2-cyanoacrylate monomer, doxorubicin, and DCM (Table 7D) permeated through SPG membrane and the monomer was rapidly polymerized in contact with a continuous phase due to catalytic action of hydroxyl anions. After solvent evaporation, PE2CA formed a polymer shell around PLGA (Figure 13e), which enabled to reduce the initial burst release of doxorubicin from the particles.

\subsubsection{Solvent removal from $\mathrm{W} / \mathrm{O} / \mathrm{W}$ or $\mathrm{S} / \mathrm{O} / \mathrm{W}$ emulsion}

\section{A. Ultrasound contrast agents}

Ultrasound contrast agents (UCAs) are gas-filled capsules with a mean diameter of 2-5 $\mu \mathrm{m}$ composed of a gas core and biodegradable lipid, protein or polymer shell. They can be 
injected into the blood flow to increase the backscattered signal from blood when insonified by ultrasound waves in Contrast Enhanced Power Doppler Sonography (Cosgrove, 2006). Targeted UCAs are UCAs containing adhesion ligands incorporated into their external surface, which allows binding to a specific cell type (Klibanov, 2007). Targeted UCAs can be retained on the endothelium at the site of pathology and used for molecular imaging or ultrasoundtriggered targeted drug release (Böhmer et al., 2009). UCA particles were fabricated by combining two-step emulsification process (ultrasonication to obtain a primary $\mathrm{W}_{1} / \mathrm{O}$ emulsion and $\mathrm{ME}$ to form a multiple $\mathrm{W}_{1} / \mathrm{O} / \mathrm{W}_{2}$ emulsion) and solvent evaporation to solidify the droplets (Figure 14a and Table 8A). Ammonium bicarbonate can be added as a porogen in the internal water phase $\mathrm{W}_{1}$ to enhance pore formation during solvent evaporation as a result of release of gas bubbles: $\mathrm{NH}_{4} \mathrm{HCO}_{3} \leftrightarrow \mathrm{NH}_{3}+\mathrm{H}_{2} \mathrm{O}+\mathrm{CO}_{2}$. The washed hardened particles were coated with mannitol and polysorbate to improve their biocompatibility, freeze dried to remove water from the core and loaded with a suitable high-molecular-weight gas, such as $\mathrm{C}_{3} \mathrm{~F}_{8}, \mathrm{C}_{4} \mathrm{~F}_{10}$ or $\mathrm{SF}_{6}$ to improve their echogenicity. SEM images revealed that the prepared particles had core/shell morphology rather than matrix structure due to coalescence of internal voids during processing (Hou et al., 2009; Liu et al., 2014).

\section{B. Synthetic biodegradable polymeric particles loaded with hydrophilic actives}

Synthetic biodegradable polymeric particles have important applications in controlled delivery of hydrophilic protein/peptide drugs (Wang et al., 2015b). Biodegradable polymeric particles loaded with hydrophilic actives can be prepared by double emulsion-solvent evaporation method. The process starts with the preparation of $\mathrm{W}_{1} / \mathrm{O}$ emulsion containing a hydrophilic active dissolved in the inner water phase $\left(\mathrm{W}_{1}\right)$ by ultrasonic or high-shear homogenisation. Ultrasonication results in smaller droplets which are more uniformly distributed in a polymer matrix after solvent evaporation (Qi et al., 2014). The second step is the formation of $\mathrm{W}_{1} / \mathrm{O} / \mathrm{W}_{2}$ emulsion by dispersing the $\mathrm{W}_{1} / \mathrm{O}$ emulsion in the outer water phase $\left(\mathrm{W}_{2}\right)$ through a membrane (Table 8B). The encapsulation efficiency, loading capacity and release rate of the encapsulated proteins (insulin, BSA, antigens) depends on the hydrophobicity and amphiphilicity of the polymer matrix (Wu et al., 2015). The release rate of insulin from insulin-loaded PLA particles was very slow (less than $20 \%$ after 70 days) due to hydrophobicity and slow degradation rate of PLA, but it was much faster using PLA/PLGA blends instead of pure PLA (Liu et al., 2006). The encapsulation efficiency and loading capacity of biodegradable polymeric particles can be significantly improved by incorporating 
an amphiphilic polymer in the polymer matrix. For example, the encapsulation efficiency of BSA-loaded PLGA particles prepared by PME was improved from 64 to $91 \%$ by adding phospholipids to the oil phase, which was attributed to the formation of protective lipid barriers at the $\mathrm{W}_{1} / \mathrm{O}$ and $\mathrm{O} / \mathrm{W}_{2}$ interfaces upon solvent evaporation, preventing BSA from diffusing out of the particles (Ma et al., 2014). Similarly, the encapsulation efficiency of hepatitis B surface antigen in PLA particles was improved from 61 to $90 \%$ by replacing PLA with PLA-mPEG diblock copolymer, which was attributed to the stabilizing effect of the amphiphilic copolymer whose hydrophilic PEG segments were oriented towards the aqueous phase and hydrophobic PLA segments towards the interior of the particle (Wei et al., 2008). Moreover, particles formed from amphiphilic polymers gave a lower initial rapid release of incorporated hydrophilic actives, known as the burst effect. For example, PELA particles prepared by PME showed lower burst effect and more constant release of recombinant human growth hormone than PLA and PLGA particles, due to the more stable interface in the presence of amphiphilic PELA polymer (Wei et al., 2011). BSA-loaded PLHMGA particles prepared by cross-flow DME system using a microsieve membrane provided a continuous release of fluorescently labelled BSA at the site of administration over a period of 3 weeks after subcapsular renal injection (Kazazi-Hyseni et al., 2015).

\section{Composite polymeric particles}

Magnetic polymeric particles were fabricated by in-situ magnetization of internal water phase in $\mathrm{W}_{1} / \mathrm{O} / \mathrm{W}_{2}$ emulsion prepared by a two-stage emulsification involving ultrasonication and PME. A multiple emulsion that was used as a template was composed of $\mathrm{FeCl}_{2} / \mathrm{FeCl}_{3}$ aqueous solution as the $\mathrm{W}_{1}$ phase and a mixture of polymer, volatile organic solvent and surfactant as the oil phase (Table 8D and Figure 14b). In-situ coprecipitation of $\mathrm{Fe}^{2+}$ and $\mathrm{Fe}^{3+}$ ions within the inner droplets was initiated by adding ammonium hydroxide to the external water phase resulting in the diffusion of $\mathrm{OH}^{-}$from $\mathrm{W}_{2}$ through $\mathrm{O}$ into $\mathrm{W}_{1}$ : $\mathrm{Fe}^{2+}+2 \mathrm{Fe}^{3+}+8 \mathrm{OH}^{-} \rightarrow \mathrm{Fe}_{3} \mathrm{O}_{4}+$ $4 \mathrm{H}_{2} \mathrm{O}$. Finally, the magnetized droplets were solidified by evaporation of DCM from the oil phase (Yang et al., 2010). Magnetic polymeric particles can also be prepared by dispersing pre-fabricated magnetite nanoparticles in the oil phase prior to ME (Omi et al., 2001).

Quantum dot (QD) loaded polymeric microparticles (QD barcodes) were prepared by emulsifying a mixture of hydrophobic QDs, pre-formed polymer (PSMA or PS) and organic solvent (toluene or DCM) in an aqueous surfactant solution through SPG membrane (Wang et al., 2013; Han et al., 2015) (Table 8E). The emulsification step was followed by solvent 
evaporation and surface functionalization of the particles in order to generate carboxyl groups, which are suitable for covalently immobilisation of antibodies. QD loaded PS particles stabilised by SDS were functionalised by exposing the negatively charged particle surface sequentially to PAH polycations and PAA polyanions (Figure 14c). After deposition of PAA, different antibodies can be covalently attached onto the particles via an EDC/NHS-mediated amidation reaction. Wang et al. (2013) generated a barcode library consisted of 12 barcodes using only one type of QDs through the combination of four intensity levels and three size levels. Different intensity levels were obtained using various concentrations of QDs in the oil phase prior to ME, while different size levels were achieved using SPG membranes with different pore sizes.

\section{Nanoclusters}

The main difference in the formulation of emulsion for production of nanoclusters and composite polymeric particles is that in the former case the oil phase does not contain any dissolved polymer, so that after solvent evaporation nanoparticles self-assemble into 3D aggregates, while in the latter case after solvent evaporation nanoparticles become embedded within the polymer matrix. Silica-coated nanoclusters with a mean size of 50-350 nm composed of magnetite nanoparticles were prepared by emulsifying a mixture of magnetite nanoparticles $(\sim 10 \mathrm{~nm})$ and hexane in an aqueous surfactant solution by ME, followed by pervaporation of hexane from nanoparticle-laden hexane droplets (Chang and Hatton, 2012). A silica layer was built-up on the surface of nanoclusters by ammonia-catalysed hydrolysis and condensation of TEOS (Figure 14d). The silica coating provides silanol groups for surface functionalization of nanoclusters with various organic ligands.

\subsubsection{Solvent removal from $\mathrm{O} / \mathrm{O}$ emulsion}

Piacentini et al. (2013c) prepared porous polyethersulfone (PES) particles by DME and subsequent nonsolvent-induced phase separation in the formed oil-in-oil $(\mathrm{O} / \mathrm{O})$ emulsion. The $\mathrm{O} / \mathrm{O}$ emulsion composed of a mixture of polymer (PES) and solvent (N,N-dimethylformamide, DMF) as a dispersed phase and a mixture of liquid paraffin, antisolvent (dodecane or isooctane) and oil-soluble surfactant as a continuous phase was prepared in the Dispersion Cell using a hydrophobic microengineered membrane. The displacement of solvent by nonsolvent immediately after droplet formation led to polymer precipitation inside the droplets and phase separation of initially homogeneous polymer solution into polymer-rich 
and polymer-poor regions (Figure 15). The process is similar to the preparation of asymmetric polymeric membranes by the Loeb-Sourirajan phase inversion method (Strathmann and Kock, 1977). In this process, a casting solution composed of a polymer/solvent mixture is immersed into the nonsolvent coagulation bath. The displacement of solvent by antisolvent causes phase separation in the casting solution resulting in the formation of a porous polymer film.

\subsection{Integration of membrane emulsification and suspension polymerisation}

Suspension polymerisation is a process in which polymer is formed within monomer or monomer-solvent droplets, which are dispersed in a continuous phase that is a nonsolvent for both the monomer and the formed polymer (Slomkowski et al., 2011). The process differs from emulsion polymerisation in two main aspects: 1) the polymerisation initiator is located in the dispersed phase; 2) synthesised polymer particles have a diameter greater than $1 \mu \mathrm{m}$, whereas in emulsion polymerisation the particle size is typically about $0.1 \mu \mathrm{m}$. The MEsuspension polymerisation (MESP) method was used to prepare polymer particles with tuneable size, shape, internal morphology, and porosity (Omi et al., 1994). Suspension polymerisation was performed within O/W (Ma et al., 2003), W/O (Hu et al., 2011) or W/O/W emulsion prepared by ME (Ma et al., 2004) and was combined with droplet swelling method to synthesise particles from hydrophilic monomers (Omi et al., 1997; Vladisavljević and Williams, 2005).

\subsubsection{Permanently porous particles}

Permanently porous particles can find applications as ion-exchangers, adsorbents, packing in chromatography columns, hydrogen storage materials, and catalyst or enzyme supports. They have been fabricated by the MESP method using porogenic solvents to induce phase separation (Lee et al., 2010; Zhou et al., 2011; Sun et al., 2005). A binding selectivity of prepared porous particles toward specific analytes can be enhanced by molecular imprinting (Kou et al., 2012).

\section{A. Permanently porous particles prepared using porogenic solvents only}

When the dispersed phase consists only of monomer(s), crosslinker and polymerisation initiator, the produced particles are hard glassy transparent beads with very low surface area in the dry state of less than $10 \mathrm{~m}^{2} \mathrm{~g}^{-1}$ (Sherrington, 1998). These polymeric particles swell in a 
thermodynamically good solvent and create a porous internal structure which is temporarily and disappears when the swollen particles are re-dispersed in a bad solvent. However, when the reaction mixture also contains a porogenic solvent at an appropriate level, the produced particles are hard but opaque, due to permanently porous structure with a high surface area ranging from $\sim 50$ to $\sim 1000 \mathrm{~m}^{2} \mathrm{~g}^{-1}$ (Sherrington, 1998). The presence of porogen is not the only condition for creation of porous structure. Polymer particles prepared with insufficient amount of crosslinker are essentially nonporous, regardless of the presence of porogen.

Lee et al. (2010) prepared porous poly(styrene-co-divinylbenzene) particles using styrene (St) as a monomer, divinylbenzene (DVB) as a crosslinker and hexadecane (HD) as a porogen (Table 9A). In this process, polymer chains are initially fully soluble in the dispersed phase, but at a certain polymer concentration phase separation occurs and the reaction mixture separates into a polymer-rich phase and a porogen-rich phase (Figure 16a). Removal of the porogen from phase-separated particles yields porous beads whose total pore volume depends on the amount of porogen added in the dispersed phase (Sherrington, 1998). The point at which phase separation occurs depends on the nature of porogen, its compatibility with the polymer network and the concentration at which it is used. A porogen must be used at a concentration that exceeds the amount needed for the maximum swelling of the polymer since otherwise all porogen will be immobilised within the polymer network and phase separation will not occur. The resulting $\mathrm{P}(\mathrm{St}-\mathrm{co}-\mathrm{DVB})$ beads can exhibit either porous matrix or core/shell morphology depending on the amount of hexadecane used. Porous beads with a matrix structure shown in Figure 16a were formed when hexadecane was added at 20-30 wt\% relative to total monomer (Lee et al., 2010). When hexadecane was used at higher concentrations (60-65 wt\% relative to total monomer), particles with a core/shell morphology were formed due to rapid phase separation during polymerisation (Figure 18a) (Lee et al., 2010). Similar to that, Ma et al. (2003c) observed that a complete engulfing of hexadecane by polystyrene or poly(styrene-co-N,N-dimethylaminoethyl methacrylate) [P(St-co-DMAEMA)] was progressively easier when the amount of hexadecane in the dispersed phase gradually increased from 10 to $50 \mathrm{wt} \%$.

In addition to the relative amount of porogen used, particle morphology can be controlled by the nature of the porogen. Hao et al. (2009) prepared porous PDVB particles with different morphologies using porogens with different molecular weight and chemical structure at the 
fixed porogen to monomer mass ratio of $1: 1$. When a porogen with a poor compatibility with the polymer was used, such as heptane, phase separation occurred at low conversion of monomer and the prepared particles had a low surface area with a large proportion of macropores $(>50 \mathrm{~nm})$. When a porogen with a good compatibility with the polymer was used (e.g. toluene), phase separation occurred at much higher conversion and the particles had a high surface area with a majority of the pores in the micropore $(<2 \mathrm{~nm})$ and mesopore (20-50 $\mathrm{nm}$ ) region. When a porogen had very poor compatibility with PDVB (e.g. hexadecane and liquid paraffin), phase separation rapidly occurred resulting in a porogen-core/polymer-shell particle morphology.

\section{B. Hypercrosslinked particles}

Surface area of porous polymer particles can be increased by post-polymerisation crosslinking of polymer chains (Urban et al., 2010). Hypercrosslinked P(St-co-DVB) particles with a surface area above $1300 \mathrm{~m}^{2} \mathrm{~g}^{-1}$ were prepared by the MESP method and subsequent crosslinking of polystyrene with chloromethyl methyl ether (Zhou et al., 2011). A two-step crosslinking process involved chloromethylation of the benzene rings of polystyrene chains (activation step) followed by the Friedel-Crafts alkylation of chloromethylated polystyrene, resulting in the formation of methylene bridges between polymer chains (Figure 27b). Porous $\mathrm{P}(\mathrm{St}-\mathrm{co}-\mathrm{DVB})$ particles can be rendered hydrophilic by the attachment of hydrophilic polymers via Friedel-Crafts acylation (Li et al., 2013).

\section{Molecularly imprinted polymer particles}

Molecularly imprinted polymer (MIP) particles are particles synthesised by polymerisation in the presence of a template molecule that is extracted afterwards, thus leaving nanocavities in the polymer network which are complementary in shape, size and chemical functionality to the template molecule (Vasapollo et al., 2011). MIP particles are capable of rebinding the original template with high sensitivity and specificity and can be used in targeted drug delivery, molecular sensing, and highly selective separation and catalytic processes. Kou et al. (2012) fabricated submicron molecularly imprinted P(MAA-co-EGDMA) particles by PME using chloramphenicol (CAP) as a template, methacrylic acid (MAA) as a functional monomer, ethylene glycol dimethacrylate (EGDMA) as a crosslinker and ethyl acetate as a porogen (Figure 17 and Table 9B). The first step was the formation of a complex between CAP and MAA in the dispersed phase liquid via self-assembly of monomer molecules around the template, followed by emulsification step by PME and polymerisation within the droplets 
in the presence of a large excess of EGDMA. After polymerisation and phase separation, the template and porogen were removed from the polymer by washing with methanol/acetic acid solution leaving behind cavities embedded in a porous polymer matrix. The prepared particles exhibited high selectivity and adsorption capacity for CAP compared to non-imprinted polymer particles prepared under the same conditions, but in the absence of CAP (Kou et al., 2012). Wolska and Bryjak (2014) fabricated 40- $\mu \mathrm{m}$ size molecularly imprinted P(MMA-coEGDMA) particles by DME using bisphenol (BPA) as a template, methyl methacrylate (MMA) as a functional monomer, ethylene glycol dimethacrylate (EGDMA) as a crosslinker and n-octane as a porogen (Table 19B). The prepared microspheres were used as highly selective sorbents for removal of BPA from aqueous solutions.

\subsubsection{Liquid-core/polymer-shell and hollow capsules}

Liquid-core/polymer-shell capsules were produced by combining ME with one-stage suspension polymerisation (Lee et al., 2010; Ma et al., 2003c), two-stage suspension polymerisation (Omi et al., 2000), interfacial polymerisation (Chu et al., 2003) or in-situ polymerisation (Pan et al., 2012; Liu et al., 2011). The prepared particles were investigated as potential candidates for encapsulation of phase change materials (Chaiyasat et al., 2009; Rahman et al., 2012) and self-healing agents (Liu et al., 2011). A liquid encapsulated within the shell can be evaporated or extracted to produce hollow polymer capsules providing excellent light scattering and thermal insulation properties that can be used as coatings, pigments, floating drug delivery systems, and catalyst supports (Liu et al., 2010).

\section{A. One-stage suspension polymerisation}

Ma et al. (2003c) prepared HD-core/PSt-shell or HD-core/P(St-co-DMAEMA)-shell particles by DME followed by one-stage suspension polymerisation using emulsion formulations given in Table 9C. A core/shell morphology with a polymer shell completely engulfing a HD core (Figure 18a) is favoured when the spreading coefficients are: $S_{1}=\gamma_{23}-\left(\gamma_{12}+\gamma_{13}\right)<0$, $S_{2}=\gamma_{13}-\left(\gamma_{12}+\gamma_{23}\right)>0$, and $S_{3}=\gamma_{12}-\left(\gamma_{13}+\gamma_{23}\right)<0$, where $\gamma_{12}$ is the interfacial tension between the HD and polymer phase, $\gamma_{13}$ is the interfacial tension between the HD and aqueous phase, and $\gamma_{23}$ is the interfacial tension between the polymer and aqueous phase. When the monomer conversion was lower, a higher amount of residual monomer was present in the HD phase, resulting in a lower $\gamma_{13}$ value and $S_{2}<0$, which led to incomplete engulfing 
of HD and a half-moon particle morphology. The incorporation of hydrophilic DMAEMA units in the polymer network decreased the $\gamma_{23}$ value and HD could be encapsulated completely even when the monomer conversion was low (Ma et al., 2003c).

\section{B. Two-stage suspension polymerisation}

Omi et al. (2000) prepared core/shell capsules with a heptane/benzene core and poly(MMAco-EGDMA-co-2-EHA) shell by two-stage suspension polymerisation. Large seed droplets composed of a heptane/benzene (4:1) mixture, the initiator and a hydrophobic monomer (2EHA) were prepared using SPG membrane and this emulsion was mixed with a fine emulsion composed of the droplets of hydrophilic monomers (MMA and EGDMA), prepared by traditional high shear methods. The oil phase of this fine emulsion was absorbed by the seed droplets (stage 1) and the swollen droplets were then polymerised (stage 2). The polymer was more hydrophilic than the porogen, resulting in phase separation with formation of a $\mathrm{HP} / \mathrm{Bz}$ core and polymer shell (Figure 18b).

\subsubsection{Nanoparticle-embedded polymeric microspheres}

Nanoparticle-embedded composite polymeric microspheres find numerous applications in biomedicine, water treatment and purification, photovoltaic devices, drug delivery, and energy storage materials (Srivastava et al., 2014). They can be prepared from preformed polymers by ME-solvent evaporation method, as explained in Figure 14b or synthesised starting from monomers by the MESP method (Takeda et al., 2009; Zhou et al., 2012; Supsakulchai et al., 2003). Takeda et al. (2009) produced acrylate microspheres filled with titanium dioxide $\left(\mathrm{TiO}_{2}\right)$ using SPG ME and subsequent suspension polymerisation (Table 9D). A uniform distribution of $\mathrm{TiO}_{2}$ particles in the acrylic monomer with very little agglomeration was achieved in a bead mill using a commercial hyperdispersant. The organic phase permeated through SPG membrane with a pore size of $2 \mu \mathrm{m}$ with no pore clogging and almost $100 \%$ yield of $\mathrm{TiO}_{2}$. When $\mathrm{TiO}_{2}$ was dispersed in the organic phase using ultrasonic cleaner, a severe membrane clogging was observed due to significant agglomeration of $\mathrm{TiO}_{2}$ in the suspension. Zhou et al. (2012) and Zhang et al. (2013) fabricated hypercrosslinked PDVB magnetic particles with a surface area above $1000 \mathrm{~m}^{2} \mathrm{~g}^{-1}$ by MESP and post-polymerisation crosslinking. $\mathrm{Fe}_{3} \mathrm{O}_{4}$ nanoparticles with a diameter of $10-15 \mathrm{~nm}$ prepared by coprecipitation of 
ferrous and ferric ions in the presence of oleic acid could be homogeneously dispersed in the oil phase and passed through a 5- $\mu \mathrm{m}$ SPG membrane without any pore clogging.

\subsection{Integration of membrane emulsification and polymerisation on droplet surface}

\subsubsection{Interfacial polycondensation}

Interfacial polycondensation is characterized by wall formation at the surface of the droplets via polycondensation of two monomers, delivered from two different phases. A hydrophobic monomer is dissolved in organic solvent and injected through the membrane into an aqueous phase. A hydrophilic monomer is added to the aqueous phase and polymerization proceeds at the surfaces of the organic phase droplets. Chu et al. (2002) prepared termosensitive capsules with a porous PA shell and PNIPAM chains grafted on the surface of the pores to act as stimuli-responsive gates (Figure 19a). A starting O/W emulsion was prepared by injecting a mixture of TDS (hydrophobic monomer), benzene and xylene into an aqueous solution of PVA and SDS using SPG membrane (Table 10A). A buffer solution containing EDA monomer was then added to the emulsion and core-shell capsules were formed by interfacial polymerisation (Chu et al., 2002). The release rate of both $\mathrm{NaCl}$ and vitamin $\mathrm{B}_{12}$ from the prepared capsules was slow at $25^{\circ} \mathrm{C}$ and fast at $40{ }^{\circ} \mathrm{C}$, since the expended PNIPAM chains blocked the diffusion at low temperatures, while the collapsed chains opened the pore space for drug release at high temperatures. A positive thermoresponse (i.e., higher release rate at higher temperature) was attributed to low graft density of PNIPAM chains in the pores (small number of grafted chains per unit pore area).

\subsubsection{In-situ polymerisation}

In ISP (in-situ polymerisation), no reactants are included in the dispersed phase and the polymerization occurs exclusively in the continuous phase and on the continuous phase side of the interface, rather than on both sides of the interface, as is the case in interfacial polymerisation. Pan et al. (2012) prepared melamine-formaldehyde (MA-FA) capsules with a shell thickness of $400 \mathrm{~nm}$ by emulsifying oil-based industrial precursor in an aqueous solution of monomers (FA and MA) in the Dispersion Cell using a microengineered nickel membrane, followed by ISP at $65^{\circ} \mathrm{C}$ (Table $10 \mathrm{~B}$ and $19 \mathrm{~b}$ ). The prepared capsules were more 
uniform that the capsules prepared using the same emulsion formulation in a high shear mixer. Liu et al. (2011) prepared melamine-urea-formaldehyde (MUF) core-shell capsules by emulsifying ENB-based self-healing agent in an aqueous solution of SDS and PVA, followed by mixing the emulsion with an aqueous solution of urea and MA-FA prepolymer and subsequent ISP at $86^{\circ} \mathrm{C}$. The prepared capsules can be incorporated into a polymeric host material with the aim of releasing ENB monomer upon crack formation that can repair the crack and therefore autonomously heal the material. The self-healing process is based on ringopening metathesis polymerisation caused by the capsule rupture (Wu et al., 2008b).

\subsection{Integration of membrane emulsification and mini-emulsion polymerisation}

In conventional emulsion polymerisation, micellar and homogenous nucleation dominate over droplet nucleation because the monomer droplets are large, which makes them ineffective in competing with monomer-swollen micelles for water-borne free radicals (Schork et al., 2005). In mini-emulsion polymerisation, polymer particles are predominantly formed by entry of free radicals from the aqueous phase into monomer droplets, because they are typically less than $0.5 \mu \mathrm{m}$ in diameter. Small droplets not only compete effectively for radicals with micelles, but also cause the micelles to dissociate by providing a large interfacial area that must be occupied by surfactant molecules. Kong et al. (2010; 2013) fabricated porous silica nanocapsules loaded with $\mathrm{Fe}_{3} \mathrm{O}_{4}$ nanoparticles and camptothecin by combining mini-emulsion polymerisation, ME, and sol-gel processing. Nanodroplets with a mean diameter of $120 \mathrm{~nm}$ composed of 10-nm magnetite nanoparticles dispersed in octane were prepared by sonication and this miniemulsion was mixed with another emulsion made up of 4- $\mu \mathrm{m}$ styrene droplets prepared by SPG DME. After mixing, styrene from the large droplets diffused through the aqueous phase into nanodroplets until a swelling equilibrium was established.

The polymerisation was initiated by adding potassium peroxydisulfate (KPS), a water-soluble initiator, in the mixed emulsion and involved the following stages (Figure 20a): (i) Formation of free radicals in the aqueous phase by thermal dissociation of KPS: $\mathrm{S}_{2} \mathrm{O}_{8}{ }^{2-} \rightarrow 2 \mathrm{SO}_{4 \bullet}^{2-}$. These radicals are too hydrophilic to enter the droplets; (ii) polymerisation of styrene in the aqueous phase resulting in oligomers of increasing molecular weight and hydrophobicity: $n M+S_{4 \bullet}^{2-} \rightarrow M_{n} S_{4 \bullet}^{2-}$; (iii) Entry of oligoradicals into monomer-swollen nanodroplets, once their chain becomes sufficiently long. The probability for styrene droplets to be 
nucleated is very low, because they are large compared to the size of nanodroplets, and hence their interfacial area is orders of magnitude smaller than that of the magnetite nanodroplets. The role of ME was to form uniform micron-sized styrene droplets without submicron-sized droplet fraction, so as to avoid nucleation of styrene droplets and formation of magnetite-free polymer particles. Therefore, in this process styrene droplets act only as monomer reservoirs and nanodroplets are nucleation sites where polymerisation occurs.

The further processing of magnetic polymer nanoparticles involved the following stages (Figure 20b): (i) formation of hydrophilic porous silica shell around the nanoparticles by the Stöber method based on the addition of TEOS and ammonia to the particle suspension; (ii) removal of polystyrene core by burning off the polymer at $400-500{ }^{\circ} \mathrm{C}$; (iii) loading hollow nanocapsules with camptothecin, a hydrophobic anticancer drug that can be trapped inside the capsules due to surface repulsion from the hydrophilic shell. The drug release was triggered by remotely applying magnetic field which caused heat generation inside magnetite nanoparticles and increased drug diffusivity (Kong et al., 2013).

\subsection{Integration of membrane emulsification and sol-gel polycondensation}

Carbon gel is a porous carbon material that can be synthesized by aqueous polycondensation of phenolic substances with formaldehyde and subsequent drying and pyrolysis in an inert atmosphere (Al-Muhtaseb and Ritter, 2003; El-Khatat and Al-Muhtaseb, 2011). Yamamoto et al. (2008) fabricated carbon cryogel microspheres using direct SPG ME (Figure 21). The first step was the polymerisation of resorcinol $(R)$ with formaldehyde (F) in water at room temperature in the presence of sodium carbonate as a catalyst. After $24 \mathrm{~h}$, RF polymer chains were formed in the solution, tangling up into RF nanoparticles ( $100 \mathrm{~nm}$ in diameter). The resulting solution (hydrosol) was injected through a hydrophobic SPG membrane to form aqueous droplets of the hydrosol in cyclohexane or cyclooctane. The emulsion was then cured in a sealed vial at $298-353{ }^{\circ} \mathrm{C}$ until the RF nanoparticles (nanoclusters) were cross-linked together to form a 3D network across the solution, resulting in a hydrogel. The gel particles were then washed with tert-butanol to exchange internal water held in the pores with tertbutanol in order to reduce shrinkage and cracking of the gel during drying. The organic gel particles were then dried under vacuum at room temperature or freeze dried and finally carbonized (pyrolyzed) in nitrogen at $1000^{\circ} \mathrm{C}$ to form porous carbon cryogel particles. Using 
SPG membrane with a pore diameter ranging from 1 to $10 \mu \mathrm{m}$, it was possible to prepare carbon cryogel particles with a mean diameter between 1 and $12 \mu \mathrm{m}$ (Yamamoto et al., 2008). Due to their high surface area, electrical conductivity, and chemical inertness, carbon aerogel particles are promising materials for catalytic applications (Moreno-Castilla and MaldonadoHódar, 2005) and hydrogen and electrical energy storage (Biener et al., 2011).

Dragosavac et al. (2012b) prepared silica gel particles from sodium silicate by a DME-based sol-gel process in the Dispersion Cell. First, an acidified sodium silicate solution at pH 3.5 was injected through a microengineered nickel membrane into kerosene in the presence of oilsoluble surfactant. The resulting W/O emulsion was stirred at room temperature until the aqueous phase droplets turned into hydrogel particles by polycondensation of silicic acid. The hydrogel silica particles were washed with acetone, dried at room temperature and calcinated at $550^{\circ} \mathrm{C}$ to form porous silica gel particles with a surface area of $360-750 \mathrm{~m}^{2} \mathrm{~g}^{-1}$. It was possible to control the particle size over a wide range from 30 to $70 \mu \mathrm{m}$ by the rate of stirring during ME. The particles were functionalised with 3-aminopropyltrimethoxysilane and used for chemisorption of copper (II) from aqueous solutions (Dragosavac et al., 2012c).

\subsection{Integration of membrane emulsification and complex coacervation}

Complex coacervation is a process during which two oppositely charged macromolecules react through associative electrostatic interactions to form a polymer-rich phase (coacervate) that is deposited around oil droplets forming a shell. Typical macromolecules used in the process are proteins derived from animal sources (gelatine, whey proteins, silk fibroin) and vegetables (soy and pea proteins), and polysaccharides such as gum arabic, pectin, chitosan, agar, alginate, carrageenan and sodium carboxymethyl cellulose (Xiao et al., 2014). Kage et al. (1997) encapsulated kerosene droplets by gelatine/acacia complex coacervation using SPG ME. Piacentini et al. (2013) prepared fish gelatine/gum arabic complex coacervates using the following steps (Figure 22): (i) Dispersion of oil in an aqueous solution of two mixed polymers (gelatine and gum arabic) using $\mathrm{DME}$ at a $\mathrm{pH} \approx 5.4$, which is above the isoelectric point (pI) of gelatine of 4.8; (ii) Complex coacervation as a result of electrostatic interactions between positively charged gelatine and anionic gum arabic caused by lowering the emulsion $\mathrm{pH}$ to 2.7-4.5; (iii) Shell formation due to deposition of the coacervates around the oil droplets; (iv) shell hardening triggered by the addition of a crosslinking agent (glytaradehyde). 
The capsule size was varied over a wide range from 40 to $240 \mu \mathrm{m}$ by controlling the shear stress on the membrane surface and the process was continuously operated using a pulsed cross flow ME system (Piacentini et al., 2013). The process can be used for encapsulation of flavours and essential oils in food, cosmetic, pharmaceutical and textile industries (Xiao et al., 2014).

\subsection{Integration of membrane emulsification and interfacial layer-by-layer electrostatic deposition}

Multilayer oil-in-water (M-O/W) emulsions are O/W emulsions consisting of oil droplets coated with multiple layers of emulsifier and/or biopolymer molecules (McClements, 2015; McClements et al., 2007). The surface charge, permeability to different species, digestibility, responsiveness to external triggers, and wettability of interfacial layers can be controlled to create $\mathrm{M}-\mathrm{O} / \mathrm{W}$ emulsions suitable for encapsulation and controlled release of bioactives (McClements et al., 2007) and coating applications (Nazir et al. 2012). M-O/W emulsions exhibit improved stability against lipid oxidation and environmental stresses, such as $\mathrm{pH}$ and ionic strength, heat treatment and freeze-thawing treatment (Gudipati et al., 2010).

M-O/W emulsions can be prepared by electrostatic LbL deposition of polyions onto the surface of oil droplets produced by ME. First, a "primary” emulsion is prepared containing oil droplets stabilised by charged emulsifier or biopolymer (Table 11). An oppositely charged polyelectrolyte is then added to the primary emulsion to form a "secondary" emulsion consisting of oil droplets coated by a two-layer interfacial membrane. This procedure can be repeated to form oil droplets coated by three or more interfacial layers. Gudipati et al. (2010) prepared a three-layer interfacial membrane around fish oil droplets consisting of negatively charged citric acid esters of mono- and diglycerides as a primary layer, cationic chitosan as a secondary layer, and anionic alginate as a tertiary layer (Figure 23a). The positively charged secondary emulsion (+56.3 mV) was more stable to transition metal-promoted lipid oxidation compared to negatively charged primary $(-45.1 \mathrm{mV})$ and tertiary emulsions $(-24.8 \mathrm{mV})$, which was attributed to electrostatic repulsion of positively charged transition metal ions from the droplet surface. However, lipid digestibility of $\mathrm{M}-\mathrm{O} / \mathrm{W}$ emulsions was progressively reduced as the number of coated layers increased (Gudipati et al., 2010). Nazir et al. (2012) prepared M-O/W emulsions suitable for applications in hair care products, consisted of silicon oil droplets coated with six interfacial layers. The multilayer coating was created by alternate 
deposition of positively charged chitosan derivative (HTCC) and negatively charged alginate or positively charged quaternary ammonium compound (DDMAC) and glycerol.

The process flexibility is significantly improved by the fact that the charge of primary droplets can be modified after emulsification using the surfactant displacement technique. If the primary droplets are stabilised by non-ionic surfactant, it is often useful to increase the droplet charge by displacing the original surfactant with another charged surfactant. For example, non-ionic Tween 20 surfactant was displaced by SDS in order to deposit positively charged chitosan chains onto negatively charged surface of modified droplets (Figure 23b).

In order to deposit negatively charged biopolymer (alginate) onto the droplets, the primary emulsion must be prepared using a positively charged surfactant, which is a major problem in SPG ME, because cationic surfactants are deposited onto the negatively charged surface of SPG membrane. In order to overcome this problem, the primary emulsion can be prepared using an amphoteric surfactant at $\mathrm{pH}>\mathrm{pKi}$ so that the surfactant will be negatively charged during SPG emulsification. After mixing the prepared emulsion with the anionic biopolymer, the $\mathrm{pH}$ of the emulsion is lowered to $\mathrm{pH}<\mathrm{pKi}$, which changes the net surfactant charge from negative to positive so that the biopolymer can be adsorbed to the droplet surfaces through electrostatic attraction. This strategy was used to prepare a primary emulsion stabilised by beta-lactoglobulin (BLG) at $\mathrm{pH} \mathrm{7,} \mathrm{which} \mathrm{was} \mathrm{above} \mathrm{the} \mathrm{isoelectric} \mathrm{point} \mathrm{of} \mathrm{BLG} \mathrm{of} \mathrm{5.2,} \mathrm{so}$ that the protein was negatively charged and did not interfere with SPG membrane. After the primary emulsion was mixed with an aqueous alginate solution, the $\mathrm{pH}$ was adjusted to 3.5 to change the protein charge and prompt alginate to adsorb on the droplet surfaces (Figure 23c).

\subsection{Integration of membrane emulsification and interfacial particle self-assembly}

A Pickering or Ramsden emulsion is an emulsion stabilised by colloidal particles adsorbed onto the interface between the two liquids (Chevalier and Bolzinger, 2013). The particles spontaneously adsorb on the interface, provided that the surface energy between the water and oil phase, $\gamma_{o w}$ exceeds the difference in interfacial tensions between the particle and the water phase, $\gamma_{p w}$ and between the particle and the oil phase, $\gamma_{p o}: \gamma_{o w}>\left|\gamma_{p w}-\gamma_{p o}\right|$. ME is an attractive method for the preparation of particle-stabilized emulsions, due to low shear environment that prevents desorption of particles from the interface. In addition, shear applied 
during emulsification process may have a significant impact on the organisation of particles at the interface and macroscopic properties and stability of Pickering emulsions (Destribats et al., 2013). For example, Pickering emulsions stabilised by soft microgel particles prepared under low shear stress environment exhibit a higher stability to flocculation than Pickering emulsions prepared under intense shearing. Pickering particles are significantly larger than surfactant molecules (100 nm to $20 \mu \mathrm{m}$ compared to $0.4-5 \mathrm{~nm}$ ), which leads to slower kinetics of adsorption at the interface and higher energy barriers to adsorption and thus, $\mathrm{ME}$ must be performed at low transmembrane flux to allow enough time for stabilisation of growing droplets prior to pinch-off. As long as the particle adsorption time is shorter than the droplet formation time it is possible to produce well controlled droplet sizes (Manga et al., 2012). Yuan et al. (2010) prepared O/W Pickering emulsions composed of ethyl acetate solutions stabilised by silica nanoparticles (80 or $800 \mathrm{~nm}$ ) using a rotating membrane reactor with stainless steel membrane and cross-flow ME with a tubular multi-channel ceramic membrane. The droplet size was controlled within the range of $1-10 \mu \mathrm{m}$ in the cross-flow system and 150-500 $\mu \mathrm{m}$ in the rotating ME system. Sabouni and Gomaa (2015) prepared O/W Pickering emulsions stabilized by metal organic frameworks (MOFs) nanoparticles (200 or $500 \mathrm{~nm}$ ) using an oscillatory woven metal microscreen emulsification system.

Colloidosomes are permeable shells composed of colloidal particles that can be fabricated by immobilising Pickering particles at the interface and removing the core liquid afterwards (Dinsmore et al., 2005). Thompson et al. (2011) prepared sunflower oil-in-water Pickering emulsions via stirred-cell membrane emulsification using poly(glycerol monomethacrylate)stabilized polystyrene latex particles. Colloidosomes were prepared by dissolving a polymer crosslinker (tolylene 2,4-diisocyanate-terminated poly(propylene glycol)) in the oil phase prior to injection through the membrane and cross-linking the latex particles from within the oil phase (Figure 24a). Sun et al. (2014) prepared Pickering O/W emulsions stabilised by poly(N-isopropylacrylamide-co-2-aminoethyl methacrylate hydrochloride) hydrogel particles via SPG membrane. The size of the emulsion droplets ranged from 10-50 $\mu \mathrm{m}$ and could be precisely controlled by the pore size of the membrane. The hydrogel particles were crosslinked at the interface by dissolving a natural crosslinking reagent (Genipin) in the oil phase.

Nan et al. (2014b) used premix SPG ME combined with polymer deposition method to prepare colloidosomes composed of alginate particles coated by chitosan (Figure 24b). The 
first step was to dissolve $5 \mathrm{wt} \%$ PLGA into ethyl acetate and to inject this organic solution through SPG membrane into a suspension of chitosan-coated particles $(230 \mathrm{~nm})$. The resultant Pickering emulsion was transferred into large amount of water to remove solvent (ethyl acetate) and deposit PLGA onto the inner surface of the shell. The obtained colloidosomes were used for oral delivery of insulin and showed high drug encapsulation efficiency (up to 97\%). Holdich et al. (2012) used similar method to prepare floating colloidosomes with photocatalytic activity using a mixture of cocoa butter and hexane as a dispersed phase and $\mathrm{TiO}_{2}$ nanoparticles as Pickering particles.

\section{Conclusions}

Microporous membranes are increasingly used in lab-scale production of single and multiple emulsions including metal-in-oil, solid-in-oil-in-water, oil-in-oil, multilayer, and Pickering emulsions. These emulsions can be utilised as templates or precursors for fabrication of structured microparticles with a size ranging from tens of nanometres to several hundred microns. High encapsulation and loading efficiencies of encapsulated materials can be achieved due to mild hydrodynamic conditions.

Droplets generated by membrane emulsification can be transformed into solid particles by implementing a variety of different chemical and physicochemical processes after emulsification step, such as polymerisation (suspension, mini-emulsion, interfacial, and insitu), ionotropic gelation, melt solidification, internal phase separation, layer-by-layer electrostatic deposition, particle self-assembly, complex coacervation, spray drying, sol-gel processing, pyrolysis, and molecular imprinting.

The examples of particles fabricated from droplets produced by membrane emulsification are ultrasound contrast agent and barcode particles for bioimaging and sensing, nanoclusters and synthetic biodegradable polymeric particles for biomedical applications, superparamagnetic porous nanoshells for remote-controlled drug release, molecularly imprinted and hypercrosslinked polymeric particles for advanced separation and catalysis, carbon aerogel particles for hydrogen and energy storage, low-melting-point metal particles for microsoldering, microgels for cell encapsulation, and liquid crystal particles for digital particle tracking. Synthesised particles can have versatile morphology (solid and hollow, matrix and core/shell, spherical and non-spherical, porous and coherent, composite and 
homogeneous) and can be loaded with hydrophilic and hydrophobic actives, quantum dots, nanoparticles, phase change materials and high molecular weight gases to achieve controlled or triggered release and impart special optical, chemical, electrical, acoustic, thermal and magnetic properties.

The advantages of membrane emulsification routes for particle synthesis are in uniform particle size that can be controlled over a wide range, low shear environment during droplet generation, versatile methods of shear generation on the membrane surface and a wide range of membranes with various pore geometries, internal structure, and surface properties. Both direct (bottom-up) and premix (top-down) membrane emulsification methods were developed offering different production rates, droplet to pore size ratios and droplet size uniformities. 
Table 1. Typical mixing ratios of raw materials in the production of SPG from $\mathrm{Na}_{2} \mathrm{O}-\mathrm{CaO}-$ $\mathrm{Al}_{2} \mathrm{O}_{3}-\mathrm{B}_{2} \mathrm{O}_{3}-\mathrm{SiO}_{2}$ mother glass (Nakashima, 2002).

\begin{tabular}{lc}
\hline & wt $^{*}{ }^{*}$ \\
\hline Shirasu & 51 \\
Limestone & 23 \\
Boric acid & 22 \\
Soda ash & 4 \\
\hline
\end{tabular}

${ }^{*} \mathrm{MgO}(\approx 5 \mathrm{wt} \%)$ and $\mathrm{ZrO}_{2}(\approx 3 \mathrm{wt} \%)$ can also be added.

Table 2. Composition of primary glass ${ }^{*}, \mathrm{SPG}^{*}$, and porous Vycor glass and Pyrex glass (Nakashima et al., 1992; Nakashima, 2002).

\begin{tabular}{lcccc}
\hline & $\begin{array}{c}\text { Primary glass } \\
\text { for SPG, wt } \%\end{array}$ & $\begin{array}{c}\text { SPG } \\
\text { wt\% }\end{array}$ & $\begin{array}{c}\text { Vycor® glass } \\
\text { wt\% }\end{array}$ & $\begin{array}{c}\text { Pyrex® glass } \\
\text { wt \% }\end{array}$ \\
\hline $\mathrm{SiO}_{2}$ & 49 & 69 & $94-99.5$ & 81 \\
$\mathrm{Al}_{2} \mathrm{O}_{2}$ & 10 & 13 & $0-0.5$ & 2 \\
$\mathrm{CaO}$ & 17 & 2 & - & - \\
$\mathrm{B}_{2} \mathrm{O}_{3}$ & 16 & 7 & $0.2-6.0$ & 13 \\
$\mathrm{Na}_{2} \mathrm{O}$ & 5 & 5 & $<0.1$ & 4 \\
$\mathrm{~K}_{2} \mathrm{O}$ & 2 & 4 & - & - \\
$\mathrm{Fe}_{2} \mathrm{O}_{3}$ & 1 & 0.4 & - & - \\
\hline
\end{tabular}

* Based on the proportions of raw materials given in Table 1. 
Table 3. Properties of commercial isotropic (symmetric) SPG membrane (Vladisavljević et al., 2005; Nakashima, 2002; Kukizaki, 2009b; Nakashima et al., 1992).

\begin{tabular}{ll}
\hline Shape & Tubes or flat discs \\
Thickness, $\delta_{m}$ & $0.4-1 \mathrm{~mm}$ \\
Compressive strength & $200-280 \mathrm{MPa}$ \\
Mean pore diameter, $d_{p}$ & $0.04-40 \mu \mathrm{m}$ \\
Porosity, $\varepsilon$ & $50-60 \%$ \\
True density & $2000-2500 \mathrm{~kg} \mathrm{~m}^{-3}$ \\
Zeta potential at pH=3-10 and $\mathrm{C}_{\mathrm{NaCl}}=1-100 \mathrm{~mol} \mathrm{~m}{ }^{-3}$ & $-15-(-45) \mathrm{mV}^{-1.4}$ \\
Pore tortuosity, $\xi$ & $1.25-1.4$ \\
Number of pores per unit cross-sectional area, $N / A_{m}$ & $10^{9}-10^{14} \mathrm{~m}^{-2}$ \\
Specific pore volume, $V_{p} / m_{m}$ & $0.5-0.6 \mathrm{dm}^{3} \mathrm{~kg}^{-1}$ \\
Hydraulic resistance, $R_{m}$ & $10^{8}-10^{12} \mathrm{~m}^{-1}$ \\
\hline
\end{tabular}


Table 4. Microparticles fabricated by integration of DME and PME using SPG membrane and various secondary reactions/processes.

\begin{tabular}{|c|c|c|c|}
\hline Product & Example & $\begin{array}{l}\text { Secondary reaction/process } \\
\text { after DME or PME }\end{array}$ & Authors \\
\hline Ceramic particles & $\begin{array}{l}\text { Silica nano- or micro- } \\
\text { particles }\end{array}$ & $\begin{array}{l}\text { Polymerisation of silicic acids by } \\
\text { interfacial or internal reaction }\end{array}$ & Kandori et al. (1992) \\
\hline $\begin{array}{l}\text { Liquid crystal } \\
\text { particles }\end{array}$ & $\begin{array}{l}\text { Thermochromic liquid } \\
\text { crystal particles }\end{array}$ & $\begin{array}{l}\text { Melt crystallization in } \mathrm{O} / \mathrm{W} \\
\text { emulsion }\end{array}$ & Segura et al. (2013) \\
\hline Carbon particles & Carbon cryogel & $\begin{array}{l}\text { sol-gel polycondensation } \\
\text { followed by freeze-drying and } \\
\text { carbonization }\end{array}$ & $\begin{array}{l}\text { Yamamoto et al. } \\
(2010)\end{array}$ \\
\hline \multirow{2}{*}{ Metal particles } & $\begin{array}{l}\text { Solder metal } \\
\text { microparticles }\end{array}$ & $\begin{array}{l}\text { Solidification of liquid metal in } \\
\mathrm{M} / \mathrm{W} \text { or } \mathrm{M} / \mathrm{O} \text { emulsion }\end{array}$ & Torigoe et al. (2011) \\
\hline & Silver nanoparticles & $\begin{array}{l}\text { Reduction of silver ions in } \mathrm{W} / \mathrm{O} \\
\text { microemulsions }\end{array}$ & Kakazu et al. (2010) \\
\hline \multirow{3}{*}{$\begin{array}{l}\text { Solid lipid } \\
\text { particles }\end{array}$} & W/S microcarrier & $\begin{array}{l}\text { Melt crystallization in } \mathrm{W} / \mathrm{O} / \mathrm{W} \\
\text { emulsion }\end{array}$ & $\begin{array}{l}\text { Kukizaki and Goto } \\
(2007 c)\end{array}$ \\
\hline & $\mathrm{S} / \mathrm{S}$ microcarrier & $\begin{array}{l}\text { Melt crystallization in S/O/W } \\
\text { emulsion }\end{array}$ & Kukizaki (2009c) \\
\hline & Coherent particles & $\begin{array}{l}\text { Melt crystallization in } \mathrm{O} / \mathrm{W} \\
\text { emulsion }\end{array}$ & $\begin{array}{l}\text { D’oria et al. (2009); Li } \\
\text { et al. (2011) }\end{array}$ \\
\hline \multirow{6}{*}{$\begin{array}{l}\text { Gel micro- and } \\
\text { nano-particles }\end{array}$} & Ca-alginate & $\begin{array}{l}\text { Crosslinking of sodium alginate } \\
\text { with } \mathrm{Ca}^{2+} \text { in } \mathrm{W} / \mathrm{O} \text { emulsion }\end{array}$ & $\begin{array}{l}\text { Liu et al. (2003) ; You } \\
\text { et al. (2001); } \\
\text { Akamatsu et al. (2011) }\end{array}$ \\
\hline & \multirow[t]{2}{*}{ Chitosan } & $\begin{array}{l}\text { Crosslinking of chitosan with } \\
\text { glutaraldehyde in W/O emulsion }\end{array}$ & $\begin{array}{l}\text { Wang et al. (2005); } \\
\text { Wei et al. (2010); Yue } \\
\text { et al. (2011); } \\
\text { Akamatsu et al. (2012) }\end{array}$ \\
\hline & & $\begin{array}{l}\text { Crosslinking of chitosan with } \\
\text { glutaraldehyde in } \mathrm{O} / \mathrm{W} / \mathrm{O} \\
\text { emulsion }\end{array}$ & Wei et al. (2013) \\
\hline & HTCC/GP & $\begin{array}{l}\text { Thermal gelation in } \mathrm{W} / \mathrm{O} \\
\text { emulsion }\end{array}$ & Wu et al. (2008) \\
\hline & Alginate/chitosan & $\begin{array}{l}\text { Coalescence of Na-alginate } \\
\text { droplets with } \mathrm{Ca}^{2+} \text { droplets and } \\
\text { particle coating with chitosan }\end{array}$ & Zhang et al. (2011) \\
\hline & Agarose & $\begin{array}{l}\text { Helix-coil transition induced by } \\
\text { cooling }\end{array}$ & $\begin{array}{l}\text { Zhou et al. (2007; } \\
2008 ; 2009)\end{array}$ \\
\hline $\begin{array}{l}\text { Protein } \\
\text { microspheres }\end{array}$ & Albumin & $\begin{array}{l}\text { Heat or chemical denaturation of } \\
\text { albumin in W/O emulsion }\end{array}$ & $\begin{array}{l}\text { El-Mahdy et al. } \\
\text { (1998) ; Muramatsu } \\
\text { and Kondo (1995); } \\
\text { Muramatsu and } \\
\text { Nakauchi (1998) }\end{array}$ \\
\hline $\begin{array}{l}\text { Composite } \\
\text { organic-inorganic } \\
\text { particles }\end{array}$ & $\begin{array}{l}\text { Polymer particles with } \\
\text { embedded } \mathrm{TiO}_{2} / \mathrm{Fe}_{3} \mathrm{O}_{4} \\
\text { nanoparticles or quantum } \\
\text { dots }\end{array}$ & $\begin{array}{l}\text { Solvent evaporation from oil } \\
\text { phase in } \mathrm{S} / \mathrm{O} / \mathrm{W} \text { emulsion }\end{array}$ & $\begin{array}{l}\text { Supsakulchai et al. } \\
(2002 ; 2002 b) \text {; Omi } \\
\text { et al. (2001) ; Wang et } \\
\text { al. (2013); Yang et al. } \\
\text { (2010); Zhou et al. } \\
(2012)\end{array}$ \\
\hline
\end{tabular}




\begin{tabular}{|c|c|c|c|}
\hline & $\begin{array}{l}\text { Polymeric particles } \\
\text { coated with silica } \\
\text { nanoparticles }\end{array}$ & $\begin{array}{l}\text { Solvent evaporation followed by } \\
\text { electrostatic layer-by-layer } \\
\text { deposition }\end{array}$ & Ito et al. (2010) \\
\hline \multirow{5}{*}{$\begin{array}{l}\text { Coherent } \\
\text { polymeric micro- } \\
\text { or nano-spheres }\end{array}$} & $\begin{array}{l}\text { PSt, P(St-co-DVB), P(St- } \\
\text { co-MMA), PUU-VP, etc. }\end{array}$ & $\begin{array}{l}\text { One-stage suspension } \\
\text { polymerization in } \mathrm{O} / \mathrm{W} \text { emulsion }\end{array}$ & $\begin{array}{l}\text { Yuyama et al. (2000); } \\
\text { Omi et al. (1994); } \\
\text { Nuisin et al. (2000); } \\
\text { Ma et al. (2003); }\end{array}$ \\
\hline & PSt-PAM composite & $\begin{array}{l}\text { One-stage suspension } \\
\text { polymerisation in } \mathrm{W} / \mathrm{O} / \mathrm{W} \\
\text { emulsion }\end{array}$ & Ma et al. (2004) \\
\hline & $\begin{array}{l}\text { P(AAm-CO-AA) and } \\
\text { PNaAMPS hydrogel }\end{array}$ & $\begin{array}{l}\text { One-stage suspension } \\
\text { polymerisation in } \mathrm{W} / \mathrm{O} \text { emulsion }\end{array}$ & $\begin{array}{l}\text { Nagashima et al. } \\
\text { (1998); Hu et al. } \\
\text { (2011) }\end{array}$ \\
\hline & $\begin{array}{l}\text { PMMA microspheres } \\
\text { and large P(St-co-DVB) } \\
\text { spheres }\end{array}$ & $\begin{array}{l}\text { Two-stage suspension } \\
\text { polymerisation in } \mathrm{O} / \mathrm{W} \text { emulsion }\end{array}$ & $\begin{array}{l}\text { Omi et al. (1995; } \\
\text { 1997) }\end{array}$ \\
\hline & PUU, PSt-PMMA, & $\begin{array}{l}\text { Solvent evaporation from oil } \\
\text { phase droplets in } \mathrm{O} / \mathrm{W} \text { emulsion }\end{array}$ & $\begin{array}{l}\text { Yuyama et al. } \\
\text { (2000b) ; Ma et al. } \\
(1999 ; 1999 b ; 1999 c)\end{array}$ \\
\hline \multirow{3}{*}{$\begin{array}{l}\text { Synthetic } \\
\text { biodegradable } \\
\text { polymer particles }\end{array}$} & $\begin{array}{l}\text { Coherent PLA and } \\
\text { PLGA spheres }\end{array}$ & $\begin{array}{l}\text { Solvent evaporation from oil } \\
\text { phase droplets in } \mathrm{O} / \mathrm{W} \text { emulsion }\end{array}$ & $\begin{array}{l}\text { Ito et. (2011); Yue et } \\
\text { al. (2012); Kanakubo } \\
\text { et al. (2010) }\end{array}$ \\
\hline & $\begin{array}{l}\text { PLA or PLGA capsules } \\
\text { for hydrophilic actives, } \\
\text { DFB loaded PLA } \\
\text { capsules }\end{array}$ & $\begin{array}{l}\text { Solvent evaporation from oil } \\
\text { phase in } \mathrm{W} / \mathrm{O} / \mathrm{W} \text { emulsion }\end{array}$ & $\begin{array}{l}\text { Liu et al. (2005; } \\
\text { 2005b; Doan et al. } \\
\text { (2011); Hou et al. } \\
\text { (2009) }\end{array}$ \\
\hline & $\begin{array}{l}\text { mPEG-PLA capsules for } \\
\text { hydrophilic actives }\end{array}$ & $\begin{array}{l}\text { Solvent extraction from oil phase } \\
\text { in } \mathrm{W} / \mathrm{O} / \mathrm{W} \text { emulsion }\end{array}$ & $\begin{array}{l}\text { Wei et al. (2008; } \\
\text { 2011) }\end{array}$ \\
\hline \multirow{7}{*}{$\begin{array}{l}\text { Core/shell and } \\
\text { hollow particles }\end{array}$} & $\begin{array}{l}\mathrm{P}(\mathrm{St}-c o-\mathrm{DMAEMA}) \\
\mathrm{P}(\mathrm{St}-\mathrm{c} o-\mathrm{DVB}), \mathrm{PDVB}\end{array}$ & $\begin{array}{l}\text { One-stage suspension } \\
\text { polymerisation and internal } \\
\text { phase separation in } \mathrm{O} / \mathrm{W} \\
\text { emulsion }\end{array}$ & $\begin{array}{l}\text { Ma et al. (2001; 2002; } \\
\text { 2003b); Lee et al. } \\
\text { (2010); Hao et al. } \\
\text { (2009) }\end{array}$ \\
\hline & $\begin{array}{l}\text { Polymer-supported } \\
\text { palladium catalyst }\end{array}$ & $\begin{array}{l}\text { One-stage suspension } \\
\text { polymerisation, internal phase } \\
\text { separation and ligand exchange }\end{array}$ & $\begin{array}{l}\text { Liu et al. (2010; } \\
\text { 2010b) }\end{array}$ \\
\hline & P(St-co-DVB-co-MAA) & $\begin{array}{l}\text { Two-stage suspension } \\
\text { polymerisation and internal } \\
\text { phase separation in O/W } \\
\text { emulsion }\end{array}$ & Wang et al. (2012) \\
\hline & $\begin{array}{l}\text { ENB-P(M-co-U-co-F) } \\
\text { core-shell capsules }\end{array}$ & In situ polymerization & Liu et al. (2011) \\
\hline & Chitosan & $\begin{array}{l}\text { Crosslinking of chitosan shell } \\
\text { onto alginate particles and core } \\
\text { dissolution }\end{array}$ & Akamatsu et al. (2010) \\
\hline & $\begin{array}{l}\text { Molecularly imprinted } \\
\text { P(MMA-co-EGDMA) } \\
\text { particles }\end{array}$ & $\begin{array}{l}\text { Molecular imprinting using CAP } \\
\text { as a template molecule }\end{array}$ & Kou et al. (2012) \\
\hline & $\begin{array}{l}\text { PGPR-PE2CA core/shell } \\
\text { particles }\end{array}$ & $\begin{array}{l}\text { Solvent evaporation followed by } \\
\text { interfacial polymerization }\end{array}$ & Lee et al. (2009) \\
\hline
\end{tabular}




\begin{tabular}{|c|c|c|c|}
\hline & $\begin{array}{l}\text { Hollow porous silica } \\
\text { nanocapsules loaded } \\
\text { with } \mathrm{Fe}_{3} \mathrm{O}_{4} \text { nanoparticles }\end{array}$ & $\begin{array}{l}\text { One-stage suspension } \\
\text { polymerisation, followed by sol- } \\
\text { gel process and calcination }\end{array}$ & $\begin{array}{l}\text { Kong et al. (2010; } \\
\text { 2012; 2013) }\end{array}$ \\
\hline \multirow{2}{*}{$\begin{array}{l}\text { Thermo- } \\
\text { responsive } \\
\text { capsules }\end{array}$} & $\begin{array}{l}\text { Porous PA shells with } \\
\text { P(NIPAM) gates in the } \\
\text { pores }\end{array}$ & Interfacial polymerisation & $\begin{array}{l}\text { Chu et al. (2002; } \\
\text { 2003) }\end{array}$ \\
\hline & $\begin{array}{l}\mathrm{P}(\mathrm{NIPAM}-\mathrm{Co}-\mathrm{AA}) \\
\text { capsules }\end{array}$ & $\begin{array}{l}\text { Suspension polymerisation in } \\
\text { W/O emulsion }\end{array}$ & $\begin{array}{l}\text { Si et al. (2011); Wang } \\
\text { et al. (2013b) }\end{array}$ \\
\hline \multirow[t]{2}{*}{ Janus particles } & $\begin{array}{l}\text { PMMA/P(St-co-BIEM)- } \\
g \text {-PDMAEMA or } \\
\text { PS/P(MMA-co-CMS)-b- } \\
\text { PDMAEMA or } \\
\text { PS/P(MMA-co-CMS) }\end{array}$ & $\begin{array}{l}\text { Solvent evaporation, followed by } \\
\text { internal phase separation and } \\
\text { atom transfer radical } \\
\text { polymerisation }\end{array}$ & $\begin{array}{l}\text { Tanaka et al. (2010); } \\
\text { Ahmad (2008) }\end{array}$ \\
\hline & PMMA/P(St-co-BIEM) & $\begin{array}{l}\text { Solvent evaporation followed by } \\
\text { internal phase separation }\end{array}$ & $\begin{array}{l}\text { Yamashita et al. } \\
\text { (2012) }\end{array}$ \\
\hline \multirow{2}{*}{$\begin{array}{l}\text { Complex } \\
\text { coacervate } \\
\text { microcapsules }\end{array}$} & $\begin{array}{l}\text { gelatin/acacia } \\
\text { microcapsules }\end{array}$ & $\begin{array}{l}\text { Complex coacervation in } \mathrm{O} / \mathrm{W} \\
\text { emulsion }\end{array}$ & Kage et al. (1997) \\
\hline & $\begin{array}{l}\text { cold water fish } \\
\text { gelatine/gum Arabic } \\
\text { microcapsules }\end{array}$ & $\begin{array}{l}\text { Complex coacervation in } \mathrm{O} / \mathrm{W} \\
\text { emulsion }\end{array}$ & Piacentini et al. (2013) \\
\hline \multirow{2}{*}{$\begin{array}{l}\text { Non-spherical } \\
\text { particles }\end{array}$} & $\begin{array}{l}\text { hemispherical polymeric } \\
\text { particles }\end{array}$ & $\begin{array}{l}\text { Cleavage of Janus particles by } \\
\text { dispersion in acetone-water or } \\
\text { THF-water solution }\end{array}$ & $\begin{array}{l}\text { Yamashita et al. } \\
\text { (2012) }\end{array}$ \\
\hline & $\begin{array}{l}\text { "Mushroom-like" } \\
\text { polymeric particles }\end{array}$ & $\begin{array}{l}\text { Selective polymerisation on one } \\
\text { half of Janus particle }\end{array}$ & Tanaka et al. (2010) \\
\hline 3D nanoclusters & $\begin{array}{l}\text { Clusters containing } \\
\text { silica-encapsulated } \\
\text { magnetite nanoparticles }\end{array}$ & $\begin{array}{l}\text { Solvent pervaporation and } \\
\text { coating of clusters with silica }\end{array}$ & $\begin{array}{l}\text { Chang and Hatton } \\
\text { (2012) }\end{array}$ \\
\hline
\end{tabular}


Table 5. Gel microbeads fabricated by integration of membrane emulsification and physical gelation process (DP - dispersed phase, $\mathrm{CP}$ - continuous phase, $\mathrm{XL}$ - crosslinking agent).

\begin{tabular}{|c|c|c|c|}
\hline Process & Product & Emulsion formulation & Authors \\
\hline \multicolumn{4}{|l|}{ A. Internal gelation } \\
\hline $\begin{array}{l}\text { DME, cross-flow } \\
\text { nickel membrane, } \\
d_{p}=2.9-5.2 \mu \mathrm{m}\end{array}$ & $\begin{array}{l}\text { Calcium alginate beads } \\
\left(\mathrm{d}_{\mathrm{part}}=44-146 \mu \mathrm{m}\right)\end{array}$ & $\begin{array}{l}\text { DP: } 0.5-2 \%(w / v) \text { sodium alginate and } 25 \\
\mathrm{mM} \mathrm{CaCO}_{3} \text { in } 0.9 \%(\mathrm{w} / \mathrm{v}) \mathrm{NaCl} \text { in water } \\
\text { CP: } 0.5-2 \%(\mathrm{v} / \mathrm{v}) \mathrm{Span} 80 \text { in paraffin oil } \\
\underline{\mathrm{XL}}: \text { glacial acetic acid }\end{array}$ & $\begin{array}{l}\text { Liu et al. } \\
\text { (2003) }\end{array}$ \\
\hline $\begin{array}{l}\text { DME, stirred cell } \\
\text { nickel } \\
\text { microengineered } \\
\text { membrane, } \mathrm{d}_{\mathrm{p}}= \\
5-20 \mu \mathrm{m}\end{array}$ & $\begin{array}{l}\text { P(NIPAM)-coated alginate } \\
\text { beads }\left(d_{\text {part }}=55-650 \mu \mathrm{m}\right)\end{array}$ & $\begin{array}{l}\text { DP: } 1.5 \text { wt } \% \text { sodium alginate }+0.5-5 \text { wt } \% \\
\mathrm{CaCO} 3 \text { in water } \\
\underline{\mathrm{CP}}: 1 \% \text { wt Span } 80 \text { in Miglyol } 840 \\
\underline{\mathrm{XL}}: \text { glacial acetic acid }\end{array}$ & $\begin{array}{l}\text { Hanga and } \\
\text { Holdich } \\
\text { (2014) }\end{array}$ \\
\hline
\end{tabular}

\section{B. External gelation}

DME, internal pressure SPG microkit $\mathrm{d}_{\mathrm{p}}=2.9 \mu \mathrm{m}$
Calcium alginate beads $\left(\mathrm{d}_{\text {part }}\right.$ $=4 \mu \mathrm{m}$ ) loaded with lidocaine $\mathrm{HCl}$, 4-acetamidophenol or sodium salicylate

DP: 2 wt $\%$ sodium alginate + drug

(drug:alginate $=0.1-1: 1$ ) in water

CP: 6 vol\% Span 80 in isooctane

$\underline{\mathrm{XL}}$ : aqueous $\mathrm{CaCl}_{2}$ solution

You et al.

(2001)

DP: $1-2$ wt $\%$ chitosan +1 wt $\%$ acetic acid +

DME using

0.5-19.6 $\mu \mathrm{m}$ SPG Chitosan beads $\left(\mathrm{d}_{\text {part }}=0.4-14\right.$ membrane, external $\mu \mathrm{m}$ )

pressure microkit

DME using

1.1-11.9 $\mu \mathrm{m}$ SPG Chitosan beads ( $\mathrm{d}_{\text {part }}$ membrane, internal $=0.75-9.5 \mu \mathrm{m}$ )

pressure microkit

Repeated PME

using 1.4-9.0 $\mu \mathrm{m}$

SPG membrane

$$
\begin{aligned}
& \text { Chitosan beads }\left(\mathrm{d}_{\text {part }}\right. \\
& =0.3-1.85 \mu \mathrm{m})
\end{aligned}
$$

DME, internal pressure SPG microkit $\mathrm{d}_{\mathrm{p}}=3 \mu \mathrm{m}$

0.9 wt $\% \mathrm{NaCl}$ in water

CP: 4 wt\% PO-500 in liquid

paraffin/petroleum ether $(7: 5, \mathrm{v} / \mathrm{v})$

$\underline{\mathrm{XL}}$ : toluene saturated with glutaraldehyde

DP: 1 wt $\%$ chitosan +2 wt $\%$ acetic acid in water

CP: 1 wt $\%$ TGCR in kerosene

$\underline{\mathrm{XL}}: 25 \mathrm{wt} \%$ glutaraldehyde in water

DP: $0.3-1 \mathrm{wt} \%$ chitosan $+1 \mathrm{wt} \%$ acetic acid in water

CP: 2-8 wt\% PO-500 in liquid

paraffin/petroleum ether $(1: 2, \mathrm{v} / \mathrm{v})$

$\underline{\mathrm{XL}}$ : Toluene saturated by glutaraldehyde

Wang et al. (2005)

Akamatsu

et al.

(2010b)

Lv et al. (2009); Ma

et al.

(2010)

DP: $10 \%(w / v) b H b+0-20 \%(w / v)$ in PBS

CP: $1.0 \mathrm{wt} \%$ TGCR in kerosene

XL: $25 \%(w / v)$ glutaraldehyde in water
Lai et al.

(2015)

\section{Cooling of emulsion to room temperature}

DME using

4.7-19.6 $\mu \mathrm{m}$ SPG Agarose beads $\left(d_{\text {part }}=15-60\right.$ membrane, external $\mu \mathrm{m}$ )

pressure microkit

DME using

23.1-29.8 $\mu \mathrm{m} \mathrm{SPG}$ membrane, stirred system with 1-12 membrane tubes $\mu \mathrm{m}$, minimum span $=0.65$ )
DP: 4 wt\% agarose +0.9 wt $\% \mathrm{NaCl}$ in water

CP: $1-6 \mathrm{wt} \%$ PO-500 in liquid paraffin/petroleum ether $(7 / 5, \mathrm{v} / \mathrm{v})$

Emulsification temperature: $55-70^{\circ} \mathrm{C}$

Zhou et al. (2007)

DP: $2-10 w t \%$ agarose $+0.9 w t \% ~ N a C l$ in water

Agarose beads $\left(\mathrm{d}_{\text {part }}=83-190\right.$

CP: 4 wt\% PO-500 in liquid

Zhao et al.

paraffin/petroleum ether $(7 / 5-12 / 0, \mathrm{v} / \mathrm{v})$

(2014) 
Repeated PME

using 10.2 $\mu \mathrm{m}$ SPG Agarose beads $\left(\mathrm{d}_{\text {part }}=5-6\right.$

external pressure

microkit

$\mu \mathrm{m})$

Repeated PME, external pressure SPG microkit, $\mathrm{d}_{\mathrm{p}}=5.7-19 \mu \mathrm{m}$ or PE membrane, $\mathrm{d}_{\mathrm{p}}=$

11.8-25.6 $\mu \mathrm{m}$
DP: $2-14 w t \%$ agarose $+0.9 w t \% ~ N a C l$ in water

CP: 4 wt\% PO-500 in liquid

paraffin/petroleum ether $(7 / 5, \mathrm{v} / \mathrm{v})$

Emulsification temperature: $60^{\circ} \mathrm{C}$

Zhou et al. (2008)

DP: $10 w t \%$ agarose $+0.9 w t \% \mathrm{NaCl}$ in

water

paraffin/petroleum ether $(7 / 5, \mathrm{v} / \mathrm{v})$

Emulsification temperature: $60^{\circ} \mathrm{C}$
CP: 4 wt\% PO-500 in liquid

Zhou et al. $\mu \mathrm{m})$

(2009)

\section{Mixing two emulsions and droplet merging}

DME using

1.1-11.9 $\mu \mathrm{m}$ SPG membrane, internal pressure microkit

Hybrid chitosan/alginate

beads $\left(\mathrm{d}_{\mathrm{part}}=1-4.4 \mu \mathrm{m}\right)$

DME using 1.1-5.4

$\mu \mathrm{m}$ SPG membrane, Chitosan beads $\left(\mathrm{d}_{\text {part }}\right.$ internal pressure $\quad=0.84-1.5 \mu \mathrm{m}$ )

microkit

$$
=0.84-1.5 \mu \mathrm{m})
$$

DME using $12 \mu \mathrm{m}$ SPG membrane, internal pressure microkit

Hollow chitosan beads $\left(\mathrm{d}_{\text {part }}\right.$ $=2.1-4.4 \mu \mathrm{m}$ ) with very thin shell

PME using 1.4, 2.8, Alginate particles $\left(\mathrm{d}_{\text {part }}\right.$ and $5.2 \mu \mathrm{m}$ SPG $\quad=300-400,500-700$, and membrane $\quad 1000-1300 \mathrm{~nm}$, resp.)
DP1: 1 wt $\%$ chitosan $+1 w t \% \mathrm{CaCl}_{2}+2 \mathrm{wt} \%$ acetic acid in water

DP2: 2 wt\% sodium alginate in water

CP: 1 wt\% TGCR in kerosene

DP1: 1 wt $\%$ chitosan +2 wt $\%$ acetic acid in

water

DP2: $10 \mathrm{wt} \%$ sodium hydroxide in water

CP: $1 \mathrm{wt} \%$ TGCR in kerosene

Akamatsu

et al.

(2010b)

Akamatsu

et al.

(2010b);

Park et al.

(2004)

DP1: alginate beads coated with chitosan gel

in water

DP2: 3 wt\% TPP in water

Akamatsu

et al.

CP: 3 wt\% Span 85 in hexane

(2010)

DP1: 1 wt\% alginate in water

DP2: $5 \mathrm{~mol} \mathrm{~L}^{-1} \mathrm{CaCl}_{2}$ in water

Nan et al.

CP: 4 wt\% PO-5S in liquid

(2014)

paraffin/petroleum ether $(1 / 2, \mathrm{v} / \mathrm{v})$

\section{E. Thermal gelation}

\begin{tabular}{|c|c|c|c|}
\hline $\begin{array}{l}\text { DME using } \\
2.8-15.4 \mu \mathrm{m} \text { SPG } \\
\text { membrane, external } \\
\text { pressure microkit }\end{array}$ & $\begin{array}{l}\text { quaternized } \\
\text { chitosan/glycerophosphate } \\
(\mathrm{HTCC} / \mathrm{GP}) \text { beads }\left(\mathrm{d}_{\text {part }}\right. \\
=7-53 \mu \mathrm{m})\end{array}$ & $\begin{array}{l}\text { DP: } 3.5 \mathrm{wt} \% \text { HTCC }+8 w t \% \text { GP in } 0.1 \mathrm{M} \\
\text { Iactic acid solution } \\
\text { CP: } 1-4 \text { wt\% PO-500 in liquid } \\
\text { paraffin/petroleum ether }(7 / 5, \mathrm{v} / \mathrm{v})\end{array}$ & $\begin{array}{l}\text { Wu et al. } \\
(2008)\end{array}$ \\
\hline $\begin{array}{l}\text { PME using } 8 \mu \mathrm{m} \\
\text { SPG membrane }\end{array}$ & $\begin{array}{l}\text { W/O/W emulsions with } \\
\text { gelled inetrnal water droplets } \\
\left(\mathrm{d}_{\text {part }}=10.5 \mu \mathrm{m} \text { after } 5 \text { passes }\right)\end{array}$ & $\begin{array}{l}\text { DP: W/O emulsion containing } 15 \text { wt } \% \text { WPI } \\
\text { in } 5 \text { mM phosphate buffer as the dispersed } \\
\text { and } 8 \% \text { PGPR in corn oil as the oil phase } \\
\text { CP: } 0.5 \text { wt } \% \text { Tween } 20 \text { in } 5 \mathrm{mM} \text { phosphate } \\
\text { buffer }\end{array}$ & $\begin{array}{l}\text { Surh et al. } \\
\text { (2007) }\end{array}$ \\
\hline
\end{tabular}


Table 6. Microparticles fabricated by membrane emulsification integrated with solidification of melted droplets (DP - dispersed phase, CP - continuous phase).

\begin{tabular}{|c|c|c|c|}
\hline Process & Product & Emulsion formulation & Authors \\
\hline $\begin{array}{l}\text { DME, cross-flow } \\
\text { SPG, } d_{p}=0.2-1 \mu \mathrm{m}\end{array}$ & $\begin{array}{l}\text { Gelucire } 44 / 14\left(\mathrm{~T}_{\mathrm{m}}=44{ }^{\circ} \mathrm{C},\right. \\
\mathrm{d}=50-130 \mathrm{~nm}) \text { or Compritol } \\
888\left(\mathrm{~T}_{\mathrm{m}}=69-74{ }^{\circ} \mathrm{C}, \mathrm{d}_{\text {part }}=\right. \\
560-760 \mathrm{~nm}) \text { particles }\end{array}$ & $\begin{array}{l}\text { DP: Gelucire } 44 / 14 \text { melt at } 65^{\circ} \mathrm{C} \text { or } \\
\text { Compritol } 888 \text { melt at } 80^{\circ} \mathrm{C} \\
\text { CP: } 0.125 \text { wt } \% \text { Tween } 20 \text { or } 1.26 \text { wt } \% \\
\text { Pluronic F68 in water } \\
\text { Method: O/W melt dispersion }\end{array}$ & $\begin{array}{l}\text { D’Oria et } \\
\text { al. (2009) }\end{array}$ \\
\hline $\begin{array}{l}\text { PME, external } \\
\text { pressure SPG } \\
\text { microkit, } d_{p}= \\
5.4-14.8 \mu \mathrm{m}\end{array}$ & $\begin{array}{l}\text { Trimyristin particles }\left(\mathrm{T}_{\mathrm{m}}=\right. \\
\left.56-57^{\circ} \mathrm{C}, \mathrm{d}_{\mathrm{part}}=55-650 \mu \mathrm{m}\right) \\
\text { with embedded solid } \\
\text { nanoparticles }\end{array}$ & $\begin{array}{l}\text { DP: S/O dispersion at } 60^{\circ} \mathrm{C}\left(\mathrm{S} \text { : vitamin } \mathrm{B}_{12}\right. \\
\text { nanoparticles }(\mathrm{d}=132 \mathrm{~nm}), \mathrm{O}: 5 \mathrm{wt} \% \text { PGPR } \\
\text { in trimyristin melt) } \\
\text { CP: } 1 \% \text { wt Tween } 40 \text { in water } \\
\text { Method: } \mathrm{S} / \mathrm{O} / \mathrm{W} \text { melt dispersion }\end{array}$ & $\begin{array}{l}\text { Kukizaki } \\
(2009 c)\end{array}$ \\
\hline $\begin{array}{l}\text { DME using 0.3-9.9 } \\
\mu \mathrm{m} \text { SPG membrane }\end{array}$ & $\begin{array}{l}\text { Tripalmitin particles }\left(\mathrm{T}_{\mathrm{m}}=65\right. \\
\left.{ }^{\circ} \mathrm{C}, \mathrm{d}_{\mathrm{part}}=3.1-32.8 \mu \mathrm{m}\right) \text { with } \\
\text { embedded water droplets }\end{array}$ & $\begin{array}{l}\text { DP: W/O emulsion at } 70{ }^{\circ} \mathrm{C}(\mathrm{W}: 1 \mathrm{wt} \% \\
\text { vitamin } \mathrm{B}_{12}+0.22 \%(\mathrm{w} / \mathrm{v}) \mathrm{NaCl} \text { in water, O: } \\
10 \mathrm{wt} \% \text { TGCR in tripalmitin melt) } \\
\text { CP: } 1 \text { wt } \% \text { DGCS }+0.22 \%(\mathrm{w} / \mathrm{v}) \mathrm{NaCl} \text { in } \\
\text { water } \\
\text { Method: W/O/W melt dispersion }\end{array}$ & $\begin{array}{l}\text { Kukizaki } \\
\text { and Goto } \\
\text { (2007c) }\end{array}$ \\
\hline $\begin{array}{l}\text { PME, packed bed of } \\
\text { glass beads, } d_{\text {bead }}= \\
30-90 \mu \mathrm{m}\end{array}$ & $\begin{array}{l}\text { Glyceryl palmitostearate } \\
\left(\mathrm{T}_{\mathrm{m}}=56^{\circ} \mathrm{C}, \mathrm{d}_{\text {part }}=1.5-2.1\right. \\
\mu \mathrm{m}) \text { particles }\end{array}$ & $\begin{array}{l}\text { DP: } 7 \text { wt\% vitamin } \mathrm{E} \text { in glyceryl } \\
\text { palmitostearate melt at } 65^{\circ} \mathrm{C} \\
\text { CP: } 2 \text { wt\% Tween } 80 \text { in water } \\
\text { Method: O/W melt dispersion }\end{array}$ & $\begin{array}{l}\text { Laouini et } \\
\text { al. (2014) }\end{array}$ \\
\hline $\begin{array}{l}\text { DME, external } \\
\text { pressure SPG } \\
\text { microkit, } d_{p}=5.5 \mu \mathrm{m}\end{array}$ & $\begin{array}{l}\text { Termochromic liquid crystal } \\
\text { particles }\left(\mathrm{T}_{\mathrm{m}}=45-47^{\circ} \mathrm{C}, \mathrm{d}_{\text {part }}\right. \\
=16 \mu \mathrm{m})\end{array}$ & $\begin{array}{l}\text { DP: Termochromic liquid crystal melt at } \\
55^{\circ} \mathrm{C} \\
\text { CP: } 5 \% \text { poloxamer } 188 \text { in water }\end{array}$ & $\begin{array}{l}\text { Segura et } \\
\text { al. (2013) }\end{array}$ \\
\hline $\begin{array}{l}\text { PME, external } \\
\text { pressure SPG } \\
\text { microkit, } d_{p}= \\
5.5-20.2 \mu \mathrm{m}\end{array}$ & $\begin{array}{l}\text { Solder particles containing } \\
4.7 \% \mathrm{Bi}, 22.6 \% \mathrm{~Pb}, 8.3 \% \mathrm{Sn} \text {, } \\
5.3 \% \mathrm{Cd} \text {, and } 19.1 \% \mathrm{In}\left(\mathrm{T}_{\mathrm{m}}=\right. \\
\left.46.8^{\circ} \mathrm{C}, \mathrm{d}_{\mathrm{part}}=4.8-11.5 \mu \mathrm{m}\right)\end{array}$ & $\begin{array}{l}\text { DP: Alloy melt at } 55^{\circ} \mathrm{C} \\
\text { CP: } 5 \text { wt } \% \text { TGCR in toluene } \\
\text { Method: M/O melt dispersion }\end{array}$ & $\begin{array}{l}\text { Torigoe et } \\
\text { al. (2011) }\end{array}$ \\
\hline $\begin{array}{l}\text { PME, external } \\
\text { pressure SPG } \\
\text { microkit, } d_{p}=20.2 \\
\mu \mathrm{m}\end{array}$ & $\begin{array}{l}\text { Solder particles containing } \\
63 \% \mathrm{Sn} \text { and } 37 \% \mathrm{~Pb}\left(\mathrm{~T}_{\mathrm{m}}=\right. \\
\left.183^{\circ} \mathrm{C}, \mathrm{d}_{\mathrm{part}}=9.3 \mu \mathrm{m}\right)\end{array}$ & $\begin{array}{l}\text { DP: } 63 \mathrm{Sn} / \mathrm{Pb} \text { melt at } 200^{\circ} \mathrm{C} \\
\underline{\mathrm{CP}}: 5 \mathrm{wt} \% \text { TGCR in lubricating oil } \\
\text { Method: M/O melt dispersion }\end{array}$ & $\begin{array}{l}\text { Torigoe et } \\
\text { al. (2011) }\end{array}$ \\
\hline
\end{tabular}


Table 7. Microparticles fabricated by integration of membrane emulsification and solvent removal from $\mathrm{O} / \mathrm{W}$ emulsion $\left(d_{p}-\right.$ pore diameter, $d_{\text {part }}$ - particle diameter).

\begin{tabular}{|c|c|c|c|}
\hline Process & Product & Emulsion formulation & Authors \\
\hline \multicolumn{4}{|c|}{ A. Coherent particles from biodegradable synthetic polymers } \\
\hline $\begin{array}{l}\text { DME, Dispersion } \\
\text { cell, metallic } \\
\text { microengineered } \\
\text { membrane, } d_{p}=10 \\
\mu \mathrm{m}\end{array}$ & $\begin{array}{l}\text { PCL particles }\left(d_{\text {part }}=15-32\right. \\
\mu \mathrm{m}, \mathrm{span}=0.51-0.6)\end{array}$ & $\begin{array}{l}\text { DP: } 8-30 \%(w / v) \text { PCL in DCM } \\
\text { CP: } 1 \text { wt } \% \text { PVA or } 2 \text { wt } \% \text { SDS + } 2 \text { wt } \% \\
\text { Tween } 80 \text { in water saturated with DCM }\end{array}$ & $\begin{array}{l}\text { Imbrogno } \\
\text { et al. } \\
(2014)\end{array}$ \\
\hline $\begin{array}{l}\text { PME, external } \\
\text { pressure SPG } \\
\text { microkit, } \mathrm{d}_{\mathrm{p}}=0.5-2 \\
\mu \mathrm{m}\end{array}$ & $\begin{array}{l}\text { PLGA particles }\left(\mathrm{d}_{\text {part }}\right. \\
=0.15-0.30 \mu \mathrm{m} \\
\mathrm{CV}=15-30 \%)\end{array}$ & $\begin{array}{l}\text { DP: } 10-50 \mathrm{mg} \mathrm{mL}^{-1} \text { PLGA in acetone } \\
\underline{\mathrm{CP}}: 1 \mathrm{wt} \% \text { PVA }\end{array}$ & $\begin{array}{l}\text { Ito et al. } \\
\text { (2011) }\end{array}$ \\
\hline $\begin{array}{l}\text { Repeated }(n=3) \\
\text { PME, external } \\
\text { pressure SPG } \\
\text { microkit, } d_{p}= \\
5.9-19.9 \mu \mathrm{m}\end{array}$ & $\begin{array}{l}\text { RIF-loaded PLGA particles } \\
\left(\mathrm{d}_{\text {part }}=0.64-5.51 \mu \mathrm{m}\right)\end{array}$ & $\begin{array}{l}\text { DP: } 3-30 w t \% \text { PLGA + 1-3 wt } \% \text { RIF in EA } \\
\text { } \frac{\mathrm{CP}}{\mathrm{pH}}=4 \%(\mathrm{w} / \mathrm{v}) \text { PVA }+8.5 \text { vol\% EA in water, } \\
\end{array}$ & $\begin{array}{l}\text { Doan et al. } \\
\text { (2011) }\end{array}$ \\
\hline $\begin{array}{l}\text { DME, external } \\
\text { pressure SPG } \\
\text { microkit, } d_{p}= \\
0.5-3.6 \mu \mathrm{m}\end{array}$ & $\begin{array}{l}\text { RIF-loaded PLGA particles } \\
\left(\mathrm{d}_{\text {part }}=1.3-9 \mu \mathrm{m}\right)\end{array}$ & $\begin{array}{l}\text { DP: } 100 \mathrm{mg} \mathrm{mL}^{-1} \mathrm{PLGA}+7.5 \mathrm{mg} \mathrm{mL}^{-1} \mathrm{RIF} \\
\text { in DCM } \\
\underline{\mathrm{CP}}: 2 \%(\mathrm{w} / \mathrm{v}) \text { PVA in water }\end{array}$ & $\begin{array}{l}\text { Ito and } \\
\text { Makino } \\
(2004)\end{array}$ \\
\hline $\begin{array}{l}\text { Repeated }(\mathrm{n}=5) \\
\text { PME, SPG } \\
\text { microkit, } \mathrm{d}_{\mathrm{p}}=2.8 \\
\mu \mathrm{m}\end{array}$ & $\begin{array}{l}\text { PLA particles as vaccine } \\
\text { adjuvants }\left(\mathrm{d}_{\text {part }}=820 \mathrm{~nm}\right)\end{array}$ & $\begin{array}{l}\text { DP: } 40 \mathrm{mg} \mathrm{mL}^{-1} \text { PLA in DCM } \\
\underline{\mathrm{CP}}: 1.9 \%(\mathrm{w} / \mathrm{v}) \text { PVA in water }\end{array}$ & $\begin{array}{l}\text { Zhang et } \\
\text { al. (2014) }\end{array}$ \\
\hline \multicolumn{4}{|c|}{ B. Liquid-core/polymer-shell capsules } \\
\hline $\begin{array}{l}\text { PME }(\mathrm{n}=1-15) \text {, } \\
\text { glass fiber syringe } \\
\text { membrane, } \mathrm{d}_{\mathrm{p}}=1 \\
\mu \mathrm{m}\end{array}$ & $\begin{array}{l}\text { DD core/PLLA shell capsules } \\
\left(\mathrm{d}_{\text {part }}=0.35-5 \mu \mathrm{m}\right)\end{array}$ & $\begin{array}{l}\text { DP: } 0.6 \text { wt } \% \text { PLLA + } 9.1 \mathrm{wt} \% \text { DD in DCM } \\
\text { CP: } 0.3 \% \text { PVA + (30 wt } \% \mathrm{MeOH} \text { or } 30 \mathrm{wt} \% \\
\text { EtOH or } 25 \mathrm{wt} \% \mathrm{PrOH}) \text { in water }\end{array}$ & $\begin{array}{l}\text { Sawalha et } \\
\text { al. (2008) }\end{array}$ \\
\hline $\begin{array}{l}\text { DME, silicon } \\
\text { nitride microsieve } \\
\text { membrane, } d_{p}=5 \\
\mu \mathrm{m}\end{array}$ & $\begin{array}{l}\text { HD core/Eudragit shell } \\
\text { capsules }\left(\mathrm{d}_{\mathrm{part}}=15-34 \mu \mathrm{m}\right)\end{array}$ & $\begin{array}{l}\text { DP: } 2-4 \text { wt } \% \text { Eudragit FS } 30 \mathrm{D}+2-15 \text { wt } \% \\
\text { HD in DCM } \\
\underline{\text { CP: }} 1 \% \text { SDS in water at pH } 5\end{array}$ & $\begin{array}{l}\text { Wagdare et } \\
\text { al. (2011) }\end{array}$ \\
\hline
\end{tabular}

\section{Janus particles}

DME, SPG

membrane, $\mathrm{d}_{\mathrm{p}}=3.9$ $\mu \mathrm{m}$

Janus PMMA/P(St-Co-BIEM) particles $\left(d_{\text {part }}=4-5 \mu \mathrm{m}\right)$

BIE

DP: $3.8 w t \%$ PMMA + $3.8 w t \% / \mathrm{P}(\mathrm{St}-\mathrm{co}-$

BIEM) in toluene

CP: $57.8 \mathrm{mM}$ SDS in water

Yamashita

et al.

(2008)

DME, SPG

membrane, $\mathrm{d}_{\mathrm{p}}=3$

$\mu \mathrm{m}$

Janus PS/P(MMA-co-CMS)

particles $\left(\mathrm{d}_{\text {part }}=3-4 \mu \mathrm{m}\right)$

DP: $3.8 w t \%$ PS + 3.8 wt $\%$ P(MMA-co-

CMS) in toluene

Ahmad et

CP: $5 \mathrm{~g} \mathrm{~L}^{-1} \mathrm{SDS}$ in water al. (2008)

\section{Polymer-core/polymer-shell capsules}

DME, external pressure SPG microkit, $\mathrm{d}_{\mathrm{p}}=1.9$ $\mu \mathrm{m}, \Delta \mathrm{p}=20 \mathrm{kPa}$
DOX-loaded PLGAcore/PE2CA-shell particles $\left(\mathrm{d}_{\text {part }}=1.4-1.9 \mu \mathrm{m}\right)$
DP: 0-5 wt \% PLGA + 0-5 wt\% E2CA +

0.05 wt $\%$ DOX in DCM

CP: $10 \mathrm{mg} \mathrm{mL}^{-1}$ SDS in water at pH 2.5
Lee et al.

(2009) 
Table 8. Microparticles fabricated by integration of membrane emulsification and solvent removal from $\mathrm{W}_{1} \mathrm{O} / \mathrm{W}_{2}$ or $\mathrm{S} / \mathrm{O} / \mathrm{W}$ emulsion $\left(d_{p}\right.$ - pore diameter, $d_{\text {part }}$ - particle diameter).

\begin{tabular}{|c|c|c|c|}
\hline Process & Product & Emulsion formulation & Authors \\
\hline \multicolumn{4}{|c|}{ A. Ultrasound contrast agent (UCA) particles } \\
\hline $\begin{array}{l}\text { DME, cross flow } \\
\text { SPG membrane, } \\
d_{p}=1.1 \mu \mathrm{m}\end{array}$ & $\begin{array}{l}\text { PLA UCA particles }\left(\mathrm{d}_{\text {part }}\right. \\
=1.99-3.58 \mu \mathrm{m})\end{array}$ & $\begin{array}{l}\underline{W}_{1}: 2.5 \text { wt } \% \text { of ammonium bicarbonate in } \\
\text { water } \\
\text { O }: 2.5 \%(w / v) \text { PLA }+1 \%(w / v) \text { Span } 80 \text { in } \\
\text { DCM } \\
\underline{W_{2}}: 1 \% \text { PVA }(w / v)+0.5 \%(w / v) \text { SDS in } \\
\text { water }\end{array}$ & $\begin{array}{l}\text { Hou et al. } \\
(2009)\end{array}$ \\
\hline $\begin{array}{l}\text { PME }(n=1-5), \text { SPG } \\
\text { membrane, } d_{p}= \\
5.2-7.2 \mu \mathrm{m}\end{array}$ & $\begin{array}{l}\text { PLLA, PLGA, PEG-b-PLLA, } \\
\text { and PEG-b-PLGA UCA } \\
\text { particles }\left(\mathrm{d}_{\text {part }}=2.0-5.2 \mu \mathrm{m}\right)\end{array}$ & $\begin{array}{l}\underline{W}_{1}: \text { water } \\
\underline{\mathrm{O}}: 5-12.5 \%(\mathrm{w} / \mathrm{v}) \text { PLLA or PLGA or PEG- } \\
\text { b-PLGA or PEG-b-PLLA in DCM } \\
\underline{\mathrm{W}}_{2}: 0.1-1 \% \text { PVA }(\mathrm{w} / \mathrm{w}) \text { in water }\end{array}$ & $\begin{array}{l}\text { Liu et al. } \\
\text { (2014) }\end{array}$ \\
\hline
\end{tabular}

\begin{tabular}{|c|c|c|c|}
\hline \multicolumn{4}{|c|}{ B. Synthetic biodegradable polymeric particles loaded with hydrophilic actives } \\
\hline $\begin{array}{l}\text { Repeated }(\mathrm{n}=3) \\
\text { PME, external } \\
\text { pressure SPG } \\
\text { microkit, } \mathrm{d}_{\mathrm{p}}= \\
5.9-19.9 \mu \mathrm{m}\end{array}$ & $\begin{array}{l}\text { PLGA particles loaded with } \\
\text { RIF \& RIF-HP } \beta C D \text { complex } \\
\left(d_{\text {part }}=2.08-8.43 \mu \mathrm{m}\right)\end{array}$ & $\begin{array}{l}\underline{\mathrm{W}}_{1}: 18 \mathrm{mg} \mathrm{mL}^{-1} \mathrm{RIF}+0.066 \mathrm{M} \mathrm{HP} \beta \mathrm{CD} \text { in } \\
50 \mathrm{mM} \text { borate buffer, } \mathrm{pH} 9 \\
\underline{\mathrm{O}}: 3-30 \mathrm{wt} \% \text { PLGA }+2 \mathrm{wt} \% \text { RIF in EA } \\
\underline{\mathrm{W}}_{2}: 3 \%(\mathrm{w} / \mathrm{v}) \text { PVA }+8.5 \text { vol\% EA, pH }=4\end{array}$ & $\begin{array}{l}\text { Doan et al. } \\
\text { (2011) }\end{array}$ \\
\hline $\begin{array}{l}\text { Repeated }(\mathrm{n}=5) \\
\mathrm{PME}, \mathrm{d}_{\mathrm{p}}=0.8-30 \\
\mu \mathrm{m}\end{array}$ & $\begin{array}{l}\text { PLGA-lipid particles loaded } \\
\text { with BSA }\left(\mathrm{d}_{\text {part }}=0.1-3 \mu \mathrm{m}\right)\end{array}$ & $\begin{array}{l}\underline{\mathrm{W}}_{1}: 60 \mathrm{mg} \mathrm{mL} \mathrm{mL}^{-1} \mathrm{BSA} \text { in water } \\
\underline{\mathrm{O}}: 2 \%(\mathrm{w} / \mathrm{v}) \text { lipid-PLGA mixture }(0-100 \\
\text { wt } \% \text { lipid in mixture) in DCM } \\
\underline{\mathrm{W}_{2}}: 0.1 \%(\mathrm{w} / \mathrm{v}) \text { PVA }\end{array}$ & $\begin{array}{l}\text { Ma et al. } \\
(2014)\end{array}$ \\
\hline $\begin{array}{l}\text { Repeated PME } \\
(\mathrm{n}=5), \mathrm{SPG} \\
\text { membrane, } \mathrm{d}_{\mathrm{p}}=0.8 \\
\mu \mathrm{m}, \Delta \mathrm{p}=2 \mathrm{MPa}\end{array}$ & $\begin{array}{l}\text { PLGA-lipid particles loaded } \\
\text { with ovalbumin }\left(\mathrm{d}_{\text {part }}=215\right. \\
\mathrm{nm})\end{array}$ & $\begin{array}{l}\underline{\mathrm{W}_{1}}: 100 \mathrm{mg} \mathrm{mL}^{-1} \text { ovalbumin in water } \\
\underline{\mathrm{O}}: 2.0 \%(\mathrm{w} / \mathrm{v}) \text { lipid/PLGA }(1: 3) \text { mixture in } \\
\mathrm{Chl} \\
\underline{\mathrm{W}_{2}}: 0.1 \%(\mathrm{w} / \mathrm{v}) \text { PVA in water }\end{array}$ & $\begin{array}{l}\text { Ma et al. } \\
\text { (2014b) }\end{array}$ \\
\hline $\begin{array}{l}\text { Repeated PME } \\
(\mathrm{n}=5), \mathrm{SPG} \\
\text { membrane, } \mathrm{d}_{\mathrm{p}}=0.8 \\
\mu \mathrm{m}, \Delta \mathrm{p}=2 \mathrm{MPa}\end{array}$ & $\begin{array}{l}\text { PLGA-lipid particles loaded } \\
\text { with ovalbumin }\left(d_{\text {part }}=558\right. \\
\text { nm, PDI }=0.045)\end{array}$ & $\begin{array}{l}\underline{\mathrm{W}_{1}}: 40 \mathrm{mg} \mathrm{mL} \mathrm{m}^{-1} \text { ovalbumin in water } \\
\underline{\mathrm{O}}: 2.0 \mathrm{wt} \% \mathrm{HSPC} / \mathrm{PLGA}(1: 2) \text { mixture in } \\
\mathrm{DCM} \\
\underline{\mathrm{W}_{2}}: 0.1 \%(\mathrm{w} / \mathrm{v}) \text { PVA in water }\end{array}$ & $\begin{array}{l}\text { Ma et al. } \\
(2014 c)\end{array}$ \\
\hline $\begin{array}{l}\text { PME, external } \\
\text { pressure SPG } \\
\text { microkit, } \mathrm{d}_{\mathrm{p}}=5.2 \\
\mu \mathrm{m}\end{array}$ & $\begin{array}{l}\text { PELA particles loaded with } \\
\text { HBsAg }\left(d_{\text {part }}=1.1-1.4 \mu \mathrm{m}\right)\end{array}$ & $\begin{array}{l}\mathrm{W}_{1}: 1.5 \mathrm{mg} \mathrm{mL}^{-1} \mathrm{HBsAg} \text { in water } \\
\underline{\mathrm{O}}: 50 \mathrm{mg} \mathrm{mL}^{-1} \text { PELA (PLA-PEG-PLA or } \\
\mathrm{PLA}-\mathrm{mPEG}) \text { in EA } \\
\underline{\mathrm{W}_{2}}: 1 \%(\mathrm{w} / \mathrm{v}) \mathrm{PVA}+1 \%(\mathrm{w} / \mathrm{v}) \mathrm{NaCl} \text { in } \\
\text { water }\end{array}$ & $\begin{array}{l}\text { Wei et al. } \\
(2008)\end{array}$ \\
\hline $\begin{array}{l}\text { DME, cross-flow } \\
\text { microsieve } \\
\text { membrane, } d_{p}=20 \\
\mu \mathrm{m}\end{array}$ & $\begin{array}{l}\text { PLGA particles loaded with } \\
\text { blue dextran }\left(\mathrm{d}_{\text {part }}=40-76\right. \\
\mu \mathrm{m})\end{array}$ & $\begin{array}{l}\underline{\mathrm{W}}_{1}: 50 \mathrm{mg} \mathrm{mL} \mathrm{mL}^{-1} \text { blue dextran in water } \\
\underline{\mathrm{O}}: 10-30 \mathrm{wt} \% \text { PLGA in DCM } \\
\underline{\mathrm{W}}_{2}: 2-6 \%(\mathrm{w} / \mathrm{v}) \text { PVA }+1.6 \% \text { DCM }(+1 \% \\
\mathrm{NaCl}) \text { in water }\end{array}$ & $\begin{array}{l}\text { Kazazi- } \\
\text { Hyseni et } \\
\text { al. (2014) }\end{array}$ \\
\hline $\begin{array}{l}\text { PME, SPG } \\
\text { membrane, } d_{p}=50.2 \\
\mu \mathrm{m}\end{array}$ & $\begin{array}{l}\text { PLGA particles loaded with } \\
\text { exenatide }\left(d_{\text {part }}=22-23 \mu \mathrm{m}\right)\end{array}$ & $\begin{array}{l}\underline{\mathrm{W}}_{1}: 30 \mathrm{mg} \mathrm{mL}^{-1} \text { exenatide in water } \\
\underline{\mathrm{O}}: 10 \%(\mathrm{w} / \mathrm{v}) \mathrm{PLGA} \text { in DCM } \\
\underline{\mathrm{W}}_{2}: 2 \%(\mathrm{w} / \mathrm{v}) \mathrm{PVA}+0.5 \%(\mathrm{w} / \mathrm{v}) \mathrm{NaCl} \text { in } \\
\text { water }\end{array}$ & $\begin{array}{l}\text { Qi et al. } \\
\text { (2014) }\end{array}$ \\
\hline $\begin{array}{l}\text { Repeated PME } \\
(\mathrm{n}=8), \text { SPG } \\
\text { membrane, } d_{p}=2.8 \\
\mu \mathrm{m}\end{array}$ & $\begin{array}{l}\text { PLGA particles loaded with } \\
\text { ovalbumin }\left(\mathrm{d}_{\text {part }}=591 \mathrm{~nm},\right. \\
\text { PDI=0.17) }\end{array}$ & $\begin{array}{l}\mathrm{W}_{1}: 100 \mathrm{mg} \mathrm{mL}^{-1} \text { ovalbumin in water } \\
\underline{\mathrm{O}}: 50 \mathrm{mg} \mathrm{mL}^{-1} \mathrm{PLGA} \text { in ethyl acetate } \\
\underline{\mathrm{W}}_{\underline{2}}: 1.5 \%(\mathrm{w} / \mathrm{v}) \mathrm{PVA}+0.9 \%(\mathrm{w} / \mathrm{v}) \mathrm{NaCl} \text { in } \\
\text { water }\end{array}$ & $\begin{array}{l}\text { Zhang et } \\
\text { al. (2014b) }\end{array}$ \\
\hline
\end{tabular}




\section{Nanoclusters}

DME, external pressure SPG microkit, $\mathrm{d}_{\mathrm{p}}=$ $0.1-0.3 \mu \mathrm{m}$
Nanoclusters of magnetite nanoparticles $\left(\mathrm{d}_{\text {part }}=50-350\right.$ $\mathrm{nm})$
DP: 3 wt $\%$ magnetite nanoparticles $(\sim 10 \mathrm{~nm}) \quad$ Chang and coated with oleic acid +97 wt $\%$ hexane Hatton CP: 0.1 wt\% SDS

\section{Composite polymeric particles prepared from $\mathrm{W} / \mathrm{O} / \mathrm{W}$ emulsion}

\begin{tabular}{|c|c|c|c|}
\hline $\begin{array}{l}\text { PME, SPG } \\
\text { membrane }\end{array}$ & $\begin{array}{l}\mathrm{P}(\mathrm{St}-\mathrm{co} \text {-HEMA }) \text { particles } \\
\left(\mathrm{d}_{\text {part }}=10-80 \mu \mathrm{m}\right) \text { loaded } \\
\text { with magnetite nanoparticles }\end{array}$ & $\begin{array}{l}\underline{\mathrm{W}}_{1}: 0.72-1.6 \mathrm{~mol} \mathrm{~L}^{-1} \mathrm{FeCl}_{3} \cdot 6 \mathrm{H}_{2} \mathrm{O}+0.36-0.8 \\
\mathrm{~mol} \mathrm{~L} \mathrm{FeCl}_{2} \cdot 4 \mathrm{H}_{2} \mathrm{O} \text { in water } \\
\text { O: }: 0.6 \mathrm{wt} \% \mathrm{P}(\mathrm{St}-\mathrm{Co}-\mathrm{HEMA})+0.25 \mathrm{wt} \% \\
\text { Span } 85 \text { or } 0.025-0.11 \mathrm{wt} \% \mathrm{PO} 310 \mathrm{in} \mathrm{DCM} \\
\underline{\mathrm{W}_{2}}: 1 \% \mathrm{PVA}(\mathrm{w} / \mathrm{v})+1 \%(\mathrm{w} / \mathrm{v}) \mathrm{Na}_{2} \mathrm{SO}_{4}+ \\
0.2 \%(\mathrm{w} / \mathrm{v}) \text { Tween } 20 \text { in water }\end{array}$ & $\begin{array}{l}\text { Yang et al. } \\
\text { (2010) }\end{array}$ \\
\hline
\end{tabular}

\section{E. Composite polymeric particles prepared from $\mathrm{S} / \mathrm{O} / \mathrm{W}$ emulsion}

DME, external pressure SPG microkit, $\left.\mathrm{d}_{\mathrm{p}}=1-4.9 \mu \mathrm{m}\right)$ loaded with QDs $\mu \mathrm{m}$

DME, internal pressure $\mathrm{SPG}, \mathrm{d}_{\mathrm{p}}=$ $15 \mu \mathrm{m}$

PS particles $\left(\mathrm{d}_{\text {part }}=24 \mu \mathrm{m}\right)$ loaded with QDs

$\mathrm{P}(\mathrm{St}-\mathrm{Co}-\mathrm{AA}), \mathrm{P}$ (St-Co-BA) or SBR particles particles $\left(\mathrm{d}_{\text {part }}\right.$ $=6-75 \mu \mathrm{m}$ ) loaded with $\mathrm{Fe}_{3} \mathrm{O}_{4}$ nanoparticles microkit, $\mathrm{d}_{\mathrm{p}}$ 1.4-9.5 $\mu \mathrm{m}$
DP: Hydrophobic QDs + 7.2 wt\% PSMA in toluene

Wang et al. CP: 0.5 wt $\%$ SDS in water

(2013)

DP: $1 \mathrm{mg} \mathrm{mL}^{-1} \mathrm{CdSe} / \mathrm{ZnS}$ QDs + $10 \%(\mathrm{w} / \mathrm{v})$ PS in DCM

CP: 1 wt\% SDS in water

Han et al. (2015)

DP: $12-17$ wt $\% \mathrm{Fe}_{3} \mathrm{O}_{4}$ nanoparticles + 3-10 wt $\%$ P(St-Co-AA) or $1.3 \mathrm{wt} \%$ SBR or $1.3-3$ wt $\% \mathrm{P}(\mathrm{St}-\mathrm{Co}-\mathrm{BA})$ in toluene Omi et al. 
Table 9. Examples of polymeric particles prepared by integration of membrane emulsification and suspension polymerisation ( $d_{p}$ - membrane pore diameter, $d_{\text {part }}$ - particle diameter).

\begin{tabular}{|c|c|c|c|}
\hline Process & Product & Emulsion formulation & Authors \\
\hline \multicolumn{4}{|c|}{ A. Permanently porous particles prepared using porogenic solvent } \\
\hline $\begin{array}{l}\text { DME, internal } \\
\text { pressure SPG } \\
\text { microkit, } \mathrm{d}_{\mathrm{p}}=1.6 \\
\mu \mathrm{m}, \Delta \mathrm{p}=28 \mathrm{kPa}\end{array}$ & $\begin{array}{l}\text { Porous } \mathrm{P}(\mathrm{St}-\mathrm{Co}-\mathrm{DVB}) \\
\text { particles }\left(\mathrm{d}_{\text {part }}=4.2 \mu \mathrm{m},\right. \\
\mathrm{CV}=18-19 \%)\end{array}$ & $\begin{array}{l}\text { DP: } 57-62 \mathrm{wt} \% \mathrm{DVB}+19-21 \mathrm{wt} \% \mathrm{St}+0.8 \\
\mathrm{wt} \% \text { AIBN }+16-23 \mathrm{wt} \% \mathrm{HD} \\
\text { CP: } 10 \mathrm{mg} \mathrm{mL}^{-1} \mathrm{PVP}+0.5 \mathrm{mg} \mathrm{mL}{ }^{-1} \mathrm{SDS}+ \\
0.5 \mathrm{mg} \mathrm{mL}^{-1} \mathrm{HQ} \text { in water }\end{array}$ & $\begin{array}{l}\text { Lee et al. } \\
\text { (2010) }\end{array}$ \\
\hline $\begin{array}{l}\text { DME, external } \\
\text { pressure SPG } \\
\text { microkit, } d_{p}=1-10 \\
\mu \mathrm{m}, \Delta \mathrm{p}=6-80 \mathrm{kPa}\end{array}$ & $\begin{array}{l}\text { Porous } \mathrm{P}(\mathrm{St}-\mathrm{Co}-\mathrm{DVB}) \\
\text { particles }\left(\mathrm{d}_{\text {part }}=3.5-40 \mu \mathrm{m} \text {, }\right. \\
\mathrm{CV}=13-17 \%)\end{array}$ & $\begin{array}{l}\text { DP: } 2.6 \text { wt\% DVB }+47.4 \text { wt } \% \mathrm{St}+49 \mathrm{wt} \% \\
\mathrm{HP}+1 \mathrm{wt} \% \mathrm{BPO} \\
\mathrm{CP}: 2-5 \mathrm{mg} \mathrm{mL}^{-1} \mathrm{PVA}+0.1-0.5 \mathrm{mg} \mathrm{mL}^{-1} \\
\mathrm{SDS}+0.2-0.3 \mathrm{mg} \mathrm{mL}^{-1} \mathrm{Na}_{2} \mathrm{SO}_{4}+0.2-0.4 \\
\mathrm{mg} \mathrm{mL}^{-1} \mathrm{MB} \text { in water }\end{array}$ & $\begin{array}{l}\text { Zhu et al. } \\
\text { (2011) }\end{array}$ \\
\hline
\end{tabular}

\section{B. Permanently porous particles prepared by molecular imprinting}

\section{$\operatorname{PME}(\mathrm{n}=5)$,}

external pressure

SPG microkit, $\mathrm{d}_{\mathrm{p}}=$

$1.4 \mu \mathrm{m}, \Delta \mathrm{p}=20 \mathrm{bar}$

DME, Dispersion

Cell, $\mathrm{d}_{\mathrm{p}}=20 \mu \mathrm{m}$,

span $=1-1.3$

\author{
Imprinted Poly(MAA-co- \\ EGDMA) particles ( $\mathrm{d}_{\text {part }}$ \\ $=0.3-0.8 \mu \mathrm{m})$
}

Imprinted Poly(MMA-coEGDMA) particles $\left(\mathrm{d}_{\text {part }}=40\right.$ $\mu \mathrm{m})$
DP: CAP + MAA + EGDMA (1:2:20 molar ratio CAP:MAA:EGDMA) + AIBN + EA CP: 1.5 wt\% PVA in water

Kou et al. (2012)

DP: 3 wt $\%$ BPA + MAA + EGDMA (4:6 mass ratio MMA:EGDMA) + AIBN + noctane

CP: 1 wt\% PVA + 2 wt\% $\mathrm{NaCl}$ in water
Wolska et

al. (2014)

\section{Liquid-core/polymer-shell particles prepared using porogenic solvent}

\begin{tabular}{|c|c|c|c|}
\hline $\begin{array}{l}\text { DME, external } \\
\text { pressure SPG } \\
\text { microkit, } d_{p}=1.4 \\
\mu \mathrm{m}\end{array}$ & $\begin{array}{l}\text { HD-core/P(St-co- } \\
\text { DMAEMA)-shell capsules } \\
\left(\mathrm{d}_{\mathrm{part}}=5.5-7.4 \mu \mathrm{m}\right. \\
\mathrm{CV}=8.2-10 \%)\end{array}$ & $\begin{array}{l}\text { DP: } 48-87 \mathrm{wt} \% \mathrm{St}+10-50 \mathrm{wt} \% \mathrm{HD}+2.2 \\
\text { wt\% DMAEMA + } 0.5 \mathrm{wt} \% \mathrm{ADVN} \\
\frac{\mathrm{CP}}{\mathrm{mg}} 4.4 \mathrm{~mL} \mathrm{~mL}^{-1} \mathrm{Na}_{2} \mathrm{SO}_{4}+0.4 \mathrm{mg} \mathrm{mL} \mathrm{mL}^{-1} \mathrm{NaNO}_{2}+0.4 \\
\mathrm{mg} \mathrm{mL}^{-1} \mathrm{SDS} \text { in water }\end{array}$ & $\begin{array}{l}\text { Ma et al. } \\
\text { (2003c) }\end{array}$ \\
\hline $\begin{array}{l}\text { DME, external } \\
\text { pressure SPG } \\
\text { microkit, } d_{p}=1.4 \\
\mu \mathrm{m}\end{array}$ & $\begin{array}{l}\text { HD-core/PSt-shell capsules } \\
\left(\mathrm{d}_{\text {part }}=7-7.4 \mu \mathrm{m},\right. \\
\mathrm{CV}=6.7-7.1 \%)\end{array}$ & $\begin{array}{l}\text { DP: } 50-65 \text { wt } \% \mathrm{St}+35-50 \mathrm{wt} \% \mathrm{HD}+0.5 \\
\text { wt } \% \text { ADVN } \\
\frac{\mathrm{CP}}{\mathrm{mg}} \mathrm{mL}^{-1} \mathrm{SDS} \text { in water }\end{array}$ & $\begin{array}{l}\text { Ma et al. } \\
(2003 c)\end{array}$ \\
\hline
\end{tabular}

\section{Composite particles}

\begin{tabular}{|c|c|c|c|}
\hline $\begin{array}{l}\text { DME, cross-flow } \\
\text { SPG, } \mathrm{d}_{\mathrm{p}}=2 \mu \mathrm{m}, \Delta \mathrm{p} \\
=8 \mathrm{kPa}\end{array}$ & $\begin{array}{l}\text { Polymer particles loaded with } \\
15 \mathrm{~nm} \mathrm{TiO}_{2} \text { nanoparticles } \\
\left(\mathrm{d}_{\text {part }} \approx 10 \mu \mathrm{m}, \mathrm{CV}=18 \%\right)\end{array}$ & $\begin{array}{l}\text { DP: } 0.94 \text { wt } \% \mathrm{TiO}_{2}+0.75 \text { wt } \% \text { Solsperse }{ }^{\circledR}+ \\
92 \mathrm{wt} \% \mathrm{NPGDMA}+5.4 \mathrm{wt} \% \mathrm{HD}+0.94 \\
\text { wt } \% \text { BPO } \\
\text { CP: } 45 \text { wt } \% \text { PVA }+0.2 \mathrm{wt} \% \text { SDS in water }\end{array}$ & $\begin{array}{l}\text { Takeda et } \\
\text { al. (2009) }\end{array}$ \\
\hline
\end{tabular}


Table 10. Examples of liquid-core/polymer-shell particles fabricated by integration of membrane emulsification and polymerisation on the droplet surface $\left(d_{p}-\right.$ membrane pore diameter, $d_{\text {part }}$ - particle diameter).

\begin{tabular}{|c|c|c|c|}
\hline Process & Product & Emulsion formulation & Authors \\
\hline \multicolumn{4}{|c|}{ A. Interfacial polycondensation } \\
\hline $\begin{array}{l}\text { DME, external } \\
\text { pressure SPG } \\
\text { microkit, } \mathrm{d}_{\mathrm{p}}=2.5 \\
\mu \mathrm{m}, \Delta \mathrm{p}=20 \text { bar }\end{array}$ & $\begin{array}{l}\text { Porous PA capsules with } \\
\text { PNIPAM chains grafted in } \\
\text { the pores }\left(\mathrm{d}_{\text {part }}=4 \mu \mathrm{m}\right)\end{array}$ & $\begin{array}{l}\text { DP: } 1.5 \mathrm{M} \text { TDC in benzene/ xylene }(2: 1 \mathrm{v} / \mathrm{v}) \\
\underline{\mathrm{CP}}: 17.3 \mathrm{mM} \text { SDS }+40.6 \mathrm{mM} \text { PVA }\end{array}$ & $\begin{array}{l}\text { Chu et al. } \\
\text { (2002) }\end{array}$ \\
\hline \multicolumn{4}{|c|}{ B. In situ polymerisation } \\
\hline $\begin{array}{l}\text { Dispersion Cell, } \\
\text { ringed nickel } \\
\text { membrane } d_{p}=15 \\
\mu \mathrm{m}, 1080 \mathrm{rpm}\end{array}$ & $\begin{array}{l}\text { Industrial precursor-core/FA- } \\
\text { MA shell capsules }\left(d_{\text {part }}=57\right. \\
\mu \mathrm{m}, \mathrm{CV}=21 \% \text {, span }=0.68)\end{array}$ & $\begin{array}{l}\text { DP: Industrial precursor } \\
\text { CP: } 1.2 \text { wt } \% \text { FA }+1.2 \mathrm{wt} \% \mathrm{MA}+0.7 \mathrm{wt} \% \\
\text { PAM-AA-Na in water at } \mathrm{pH}=4.3\end{array}$ & $\begin{array}{l}\text { Pan et al. } \\
(2012)\end{array}$ \\
\hline $\begin{array}{l}\text { DME, internal } \\
\text { pressure SPG } \\
\text { microkit, } \mathrm{d}_{\mathrm{p}}=10 \\
\mu \mathrm{m}, \Delta \mathrm{p}=2 \mathrm{kPa}\end{array}$ & $\begin{array}{l}\text { ENB-core/MUF-shell } \\
\text { capsules }\left(\mathrm{d}_{\text {part }}=46 \mu \mathrm{m} \text {, span }\right. \\
=0.71)\end{array}$ & $\begin{array}{l}\text { DP: } \mathrm{ENB} \\
\underline{\mathrm{CP}}: 0.3 \mathrm{wt} \% \mathrm{SDS}+4.5 \mathrm{wt} \% \text { PVA in water }\end{array}$ & $\begin{array}{l}\text { Liu et al. } \\
\text { (2011) }\end{array}$ \\
\hline
\end{tabular}


Table 11. Preparation of multilayer O/W emulsions by ME and LbL electrostatic deposition. A primary emulsion containing droplets coated with ionic surfactant was prepared by ME and modified by sequential adsorption of oppositely charged biopolymers $\left(d_{p}\right.$ - membrane pore diameter, $\xi_{n}$ - zeta potential of $n$-layer emulsion droplets; for primary emulsion $n=1$ ).

\begin{tabular}{|c|c|c|c|}
\hline Process & Product & Primary emulsion & Authors \\
\hline $\begin{array}{l}\text { PME (n=1-4), SPG } \\
\text { high-speed kit, } \mathrm{d}_{\mathrm{p}}= \\
10 \mu \mathrm{m}, \\
\Delta \mathrm{p}=150-200 \mathrm{kPa}\end{array}$ & $\begin{array}{l}\text { Two-layer sunflower O/W } \\
\text { emulsion stabilised by WPI- } \\
\text { CMC or WPI-(WPI-CMC) } \\
\xi_{2}=-23 \text { or }-28 \mathrm{mV} \text {, resp. }\end{array}$ & $\begin{array}{l}\text { DP: sunflower oil } \\
\text { CP: } 1 \text { wt\% WPI in } 0.01 \mathrm{M} \text { acetic acid at } \\
\mathrm{pH}=3.8 \\
\phi_{1}=0.2, \xi_{1}=+54 \mathrm{mV}\end{array}$ & $\begin{array}{l}\text { Berendsen et } \\
\text { al. (2014) }\end{array}$ \\
\hline $\begin{array}{l}\text { PME, external } \\
\text { pressure SPG } \\
\text { microkit, } d_{p}=4 \mu \mathrm{m}\end{array}$ & $\begin{array}{l}\text { Two-layer corn } \mathrm{O} / \mathrm{W} \\
\text { emulsion }\left(\mathrm{d}_{3,2}=6.6 \mu \mathrm{m}\right) \\
\text { stabilised by BLG-alginate } \\
\xi_{2}=-38 \mathrm{mV}\end{array}$ & $\begin{array}{l}\text { DP: corn oil } \\
\text { CP: } 5 \text { wt } \% \text { BLG in } 5 \mathrm{mM} \text { phosphate } \\
\text { buffer at } \mathrm{pH}=7.0 \\
\phi_{1}=0.2, \xi_{1}=-32 \mathrm{mV}\end{array}$ & $\begin{array}{l}\text { Li and } \\
\text { McClements } \\
\text { (2014) }\end{array}$ \\
\hline $\begin{array}{l}\text { PME, external } \\
\text { pressure SPG } \\
\text { microkit, } \mathrm{d}_{\mathrm{p}}=3 \mu \mathrm{m}\end{array}$ & $\begin{array}{l}\text { Two-layer fish O/W } \\
\text { emulsion }(\mathrm{d}=12.9 \mu \mathrm{m}) \\
\text { stabilised by SDS-SBCS } \\
\xi_{2}=+(60-90) \mathrm{mV}\end{array}$ & $\begin{array}{l}\text { DP: fish oil } \\
\underline{\mathrm{CP}}: 0.25 \%(\mathrm{w} / \mathrm{v}) \mathrm{SDS} \text { at } \mathrm{pH}=6 \\
\phi_{1}=0.09, \xi_{1}=-101 \mathrm{mV}\end{array}$ & $\begin{array}{l}\text { Chatterjee and } \\
\text { Judeh (2015) }\end{array}$ \\
\hline $\begin{array}{l}\text { PME }(\mathrm{n}=5) \text {, } \\
\text { external pressure } \\
\text { SPG microkit, } \mathrm{d}_{\mathrm{p}}= \\
8 \mu \mathrm{m}, \Delta \mathrm{p}=100 \mathrm{kPa}\end{array}$ & $\begin{array}{l}\text { Three-layer corn O/W } \\
\text { emulsion stabilised by Tween } \\
\text { 20-SDS-chitosan } \\
\xi_{3}=+43 \mathrm{mV}\end{array}$ & $\begin{array}{l}\text { DP: corn oil } \\
\text { CP: } 0.5 \mathrm{wt} \% \text { Tween } 20+100 \mathrm{mM} \text { acetic } \\
\text { acid }+10 \mathrm{mM} \mathrm{NaCl}(\mathrm{pH}=3.0) \\
\phi_{1}=0.2, \xi_{1}=-12 \mathrm{mV}\end{array}$ & $\begin{array}{l}\text { Vladisavljević } \\
\text { and } \\
\text { McClements } \\
\text { (2010) }\end{array}$ \\
\hline $\begin{array}{l}\text { PME, external } \\
\text { pressure SPG } \\
\text { microkit, } \mathrm{d}_{\mathrm{p}}=8 \mu \mathrm{m}\end{array}$ & $\begin{array}{l}\text { Three-layer fish } \mathrm{O} / \mathrm{W} \\
\text { emulsion }\left(\mathrm{d}_{4,3}=5.3-5.7 \mu \mathrm{m}\right) \\
\text { stabilised by Citrem- } \\
\text { chitosan-alginate } \\
\xi_{3}=-25 \mathrm{mV}\end{array}$ & $\begin{array}{l}\text { DP: fish oil } \\
\text { CP: } 0.5 \mathrm{wt} \% \text { Citrem in } 100 \mathrm{mM} \text { acetate } \\
\text { buffer at } \mathrm{pH}=3.5 \\
\phi_{1}=0.05, \xi_{1}=-45 \mathrm{mV}\end{array}$ & $\begin{array}{l}\text { Gudipati et al. } \\
\text { (2010) }\end{array}$ \\
\hline $\begin{array}{l}\text { DME, SPG } \\
\text { microkit, } d_{p}=5.3 \\
\mu \mathrm{m}\end{array}$ & $\begin{array}{l}\text { Six-layer silicone } \mathrm{O} / \mathrm{W} \\
\text { emulsion }(\mathrm{d}=15.5 \mu \mathrm{m}) \\
\text { stabilised by } 3 \text { successive } \\
\text { HTCC-alginate or DDMAC- } \\
\text { glycerol layers } \\
\xi_{6}=-42 \text { or }-30 \mathrm{mV} \text {, resp }\end{array}$ & $\begin{array}{l}\text { DP: silicone oil } \\
\text { CP: } 1.5 \text { wt } \% \text { Brij- } 35+0.5 \text { wt } \% \text { Triton X- } \\
405 \text { in deionized water } \\
\phi_{1}=0.16, \xi_{1}=-33 \mathrm{mV}\end{array}$ & $\begin{array}{l}\text { Nazir et al. } \\
\text { (2012) }\end{array}$ \\
\hline
\end{tabular}




\section{Abbrevations and trade names}

Chemicals and materials: AA, acrylic acid; AB, antibody; AIBN, 2,2-azobisisobutyronitrile; ADVN, N,N'-azobis(2,4-dimethylvaleronitrile); APTES, (3-aminopropyl)-triethoxysilane); APTMS, (3-aminopropyl)-trimethoxysilane; bHb bovine hemoglobin; BSA, bovine serum albumin; HAPI, Hydrophilic active principle ingredient; API, active principle ingredient; BLG, $\beta$-lactoglobulin; Bz: benzene; BPA, bisphenol A; BPO, benzoyl peroxide; Brij-35, polyoxyethylene (10) lauryl ether; DMAEMA, dimethylaminoethyl methacrylate; CAP, chloramphenicol; Chl, cholesterol; CMC, carboxymethyl cellulose; Citrem (DuPont), citric acid esters of monoglycerides; CMS, chloromethylstyrene; CTAB, cetyltrimethyl-ammonium bromide; DCM, dichloromethane; DD, dodecane; DDMAC, diallyl dimethyl ammonium chloride; DFB, decafluorobutane; DGCS, decaglycerin condensed stearic acid ester; DOX, doxorubicin, DVB, divinylbenzene; E2CA, ethyl 2-cyanoacrylate; EA, ethyl acetate; EDA, ethylenediamine; EDC, ethyl(dimethylaminopropyl) carbodiimide; EGDMA, ethylene glycol dimethacrylate; 2-EHA, 2-ethylhexyl acrylate; ENB, 5-ethylidene-2-norbornene; EtOH, ethanol; Eudragit FS 30D, poly(methyl acrylate-co-methyl methacrylate-co-methacrylic acid); formaldehyde, FA; GP, $\alpha$ - $\beta$ - glycerophosphate; HAI, hydrophilic active ingredient; HBsAg, hepatitis B surface antigen; HD, hexadecane; HP, n-heptane; HP $\beta C D$, (2-hydroxypropyl- $\beta$ cyclodextrin; HQ, hydroquinone; HSPC, hydrogenated phosphatidylcholine; HTCC, $N$-[(2hydroxy-3-trimethylammonium) propyl] chitosan chloride; MA, melamine; MAA, methacrylic acid; MB, methylene blue; methacrylic acid; $\mathrm{MeOH}$, methanol; MA-FA, melamine-formaldehyde; MUF, melamine-urea-formaldehyde; MMA, methyl methacrylate; mPEG, poly(monomethoxypoly ethylene glycol); NHS, N-Hydroxysuccinimide; NIPAM, Nisopropylacrylamide; NPGDMA, neopentyl glycol dimethacrylate; PA, polyamide; PAA, poly(acrylic acid); PAH, poly(allylamine hydrochloride); PAM, polyacrylamide; PO-5S, hexaglycerol penta oleate; PAM-AA-Na, poly(acrylamide-co-sodium acrylate); PAH, poly(allylamine hydrochloride); ODS, octadecyldimethylchlorosilane; PBS, phosphatebuffered saline; PCL, polycaprolactone; PDM, poly(2-dimethylaminoethyl methacrylate); PDVB, polydivinylbenzene; PE2CA, poly(ethyl 2-cyanoacrylate); PEG, poly(ethylene glycol); PGPR, polyglycerol polyricinoleate; PLA, polylactic acid or polylactide; PLGA, poly(lactic-co-glycolic acid); PLHMGA, poly(lactic-co-hydroxymethyl glycolic acid); PLLA, poly(L-lactic acid); P(M-co-U-co-F), PMMA, poly(methyl methacrylate); PNIPAM, poly(Nisopropylacrylamide); PNaAMPS, poly(sodium 2-(acrylamido)-2-methylpropanesulfonate); 
PO 310, tetraglycerol pentaoleate; PP, polypropylene; PPC, poly(propylene carbonate); PrOH, 2-propanol; PS, polystyrene; P(St-co-BIEM), poly(styrene-2-(2-bromoisobutyryloxy)ethyl methacrylate; P(St-co-HEMA), poly(styrene-co-2-hydroxyethyl methacrylate); PSMA, poly(styrene-co-maleic anhydride); PUU, polyurethaneurea; PVA, polyvinylalcohol; PVP, Poly(vinyl pyrrolidone); QD, quantum dot; RF, resorcinol-formaldehyde; RIF, rifampicin; Solsperse ${ }^{\circledR}$, dispersant (Lubrizol); SA, stearic acid; SBCS, N-stearoyl O-butylglyceryl chitosan; SDS, sodium dodecyl sulfate; Span 80, sorbitan monooleate; Span 85, Sorbitane trioleate; SPG, Shirasu porous glass; St, styrene; SU-8, negative photoresist from Shell Chemical; TEOS, tetraethylorthosilicate; TDC, terephthaloyl dichloride; TGCR, tetraglycerol condensed ricinoleate; THF, tetrahydrofuran; TMS, trimethylchlorosilane; TPP, tripolyphosphate; Triton X-405, octylphenol ethoxylate; Tween 20, polyoxyethylene (20) sorbitan monolaurate; Tween 80, Polyoxyethylene (20) sorbitan monooleate; UCA, ultrasound contrast agent; VP, vinyl polymer; WPH, whey protein hydrolysate; WPI, whey protein isolate.

Emulsions/dispersions: M/O, metal-in-oil; M-O/W, multilayer oil-in-water, M/W, metal-inwater; O/O, oil-in-oil; O/W, oil-in-water; O/W/O, oil-in-water-in-oil; S/O, solid-in-oil; S/O/W, solid-in-oil-in-water; S/S, solid-in-solid; W/O, water-in-oil, W/O/W, water-in-oil-in-water.

Other: ATRP, atom transfer radical polymerisation; CFD, computational fluid dynamics; DME, direct membrane emulsification; DRIE, deep reactive ion etching; ISP, in situ polymerisation; LIGA, Ger. LIthographie, Galvanoformung, Abformung (lithography, electroplating, and moulding), MESP, membrane emulsification-suspension polymerisation; PECVD, plasma-enhanced chemical vapor deposition; PME, premix membrane emulsification; RIE, reactive ion etching; UCST, upper critical solution temperature.

\section{Symbols}

$\begin{array}{ll}A_{m} & \text { Cross-sectional area of membrane } \\ a & \text { Ratio of mean droplet size in pre-mix to mean pore size } \\ C a & \text { Capillary number } \\ D_{h, p} & \text { Hydraulic pore diameter } \\ d_{d} & \text { Droplet diameter } \\ d_{p} & \text { Mean pore diameter }\end{array}$




\begin{tabular}{|c|c|}
\hline$d_{\text {part }}$ & Particle diameter \\
\hline$E_{a}$ & Activation energy for spinodal decomposition \\
\hline$F_{c a}$ & Capillary force \\
\hline$F_{d}$ & Drag force \\
\hline$J$ & Transmembrane flux \\
\hline K & Proportionality constant in Eq. (1) \\
\hline$K^{\prime}, K_{1}^{\prime}$ & Proportionality constant between pore diameter and droplet diameter \\
\hline$K^{\prime \prime}$ & Proportionality constant in Eq. (10) \\
\hline$m_{m}$ & Mass of dry membrane \\
\hline$N$ & Total number of pores in membrane \\
\hline$n$ & Exponent in Eq. (10) \\
\hline$Q$ & Volume flow rate \\
\hline$P$ & Pressure \\
\hline$P_{\text {cap }}$ & Capillary pressure \\
\hline$R$ & Universal gas constant $\left(8314 \mathrm{~kJ} \mathrm{kmol}^{-1} \mathrm{~K}^{-1}\right)$ \\
\hline$R_{m}$ & Hydraulic resistance of membrane \\
\hline$S$ & Spreading coefficient \\
\hline$r_{p}$ & Pore radius \\
\hline$T$ & Temperature \\
\hline$T_{m}$ & Melting point \\
\hline$T_{1}$ & Initial temperature of mother glass \\
\hline$T_{2}$ & Temperature of glass phase separation \\
\hline$T_{g}$ & Glass transition temperature \\
\hline$t$ & Time \\
\hline$U$ & Velocity \\
\hline$V_{c}$ & Continuous phase volume \\
\hline$V_{p}$ & Total pore volume in membrane \\
\hline$x$ & Mass fraction \\
\hline$\gamma_{i j}$ & Interfacial tension between phase $i$ and phase $j$ \\
\hline$\delta_{m}$ & Membrane thickness \\
\hline
\end{tabular}


Membrane porosity

$\varepsilon_{\text {part }}$

Particle porosity

$\phi$

Volume fraction

$\eta$

Viscosity

$\rho$

Density

$\xi$

Pore tortuosity

$\theta$

Contact angle

$\tau_{w}$

Shear stress on surface

\section{Subscripts}

C

Continuous phase

cr

Critical

d

Dispersed phase

e

Emulsion

i

Acid insoluble phase

o

Oil phase

aq

Aqueous phase

$\mathrm{p}$

Pore

pol

Polymer

$\mathrm{S}$

Acid soluble phase

1

Polymer 1 rich phase or porogen rich phase

2

Polymer 2 rich phase or polymer rich phase

3

Aqueous phase 


\section{References}

Abrahamse, A.J., van Lierop, R., van der Sman, R.G.M., van der Padt, A. and Boom, R.M. (2002) 'Analysis of droplet formation and interactions during cross-flow membrane emulsification', J. Membr. Sci., 204: 125-137.

Ahmad, H., Saito, N., Kagawa, Y. and Okubo, M. (2008) 'Preparation of micrometer-sized, monodisperse "Janus" composite polymer particles having temperature-sensitive polymer brushes at half of the surface by seeded atom transfer radical polymerization', Langmuir, 24: 688-691.

Akamatsu, K., Chen, W., Suzuki, Y., Ito, T., Nakao, A., Sugawara, T., Kikuchi, R. and Nakao, S. (2010) 'Preparation of monodisperse chitosan microcapsules with hollow structures using the SPG membrane emulsification technique', Langmuir, 26: 14854-14860.

Akamatsu, K., Kaneko, D., Sugawara, T., Kikuchi, R. and Nakao, S. (2010b) 'Three preparation methods for monodispersed chitosan microspheres using the Shirasu porous glass membrane emulsification technique and mechanisms of microsphere formation', Ind. Eng. Chem. Res., 49: 3236-3241.

Akamatsu, K., Maruyama, K., Chen, W., Nakao, A. and Nakao, S. (2011) 'Drastic difference in porous structure of calcium alginate microspheres prepared with fresh or hydrolyzed sodium alginate’, J. Colloid Interface Sci., 371: 46-51.

Akamatsu, K., Ikeuchi, Y., Nakao, A. and Nakao, S. (2012) 'Size-controlled and monodisperse enzyme-encapsulated chitosan microspheres developed by the SPG membrane emulsification technique', J. Colloid Interface Sci., 363: 707-710.

Al-Muhtaseb, S.A. and Ritter, J.A. (2003) 'Resorcinol-formaldehyde organic and carbon gels', Adv. Mater., 15: 101-114.

Aryanti, N., Williams, R.A., Hou, R. and Vladisavljević, G.T. (2006) 'Performance of rotating membrane emulsification for O/W production', Desalination, 200: 572-574.

Berendsen, R., Güell, C., Henry, O. and Ferrando, M. (2014) 'Premix membrane emulsification to produce oil-in-water emulsions stabilized with various interfacial structures of whey protein and carboxymethyl cellulose’, Food Hydrocolloids, 38: 1-10.

Berendsen, R., Güell, C. and Ferrando, M. (2015) 'Spray dried double emulsions containing procyanidin-rich extracts produced by premix membrane emulsication: effect of interfacial composition', Food Chem., 178: 251-258. 
Biener, J., Stadermann, M., Suss, M., Worsley, M.A., Biener, M.M., Rose, K.A. and Baumann, T.F. (2011) 'Advanced carbon aerogels for energy applications', Energy Environ. Sci., 4: 656-667.

Böhmer, M.R., Klibanov, A.L., Tiemann, K., Hall, C.S., Gruella, H. and Steinbach, O.C. (2009) 'Ultrasound triggered image-guided drug delivery’, Eur. J. Radiol., 70: 242-253.

Bao, D. and Zhao, Y. (2010) 'Building membrane emulsification into pulmonary drug delivery and targeting', Pharm. Res., 27: 2505-2508.

Brans, G., Kromkamp, J., Pek, N., Gielen, J., Heck, J., van Rijn, C.J.M., van der Sman, R.G.M, Schroën, C.G.P.H. and Boom, R.M. (2006) 'Evaluation of microsieve membrane design', J. Membr. Sci., 278: 344-348.

Chaiyasat, P., Suzuki, T., Minami, H. and Okubo, M. (2009) 'Thermal properties of hexadecane encapsulated in poly(divinylbenzene) particles', J. Appl. Polym. Sci., 112: 3257-3266.

Chang, E.P. and Hatton, T.A. (2012) 'Membrane emulsification and solvent pervaporation processes for the continuous synthesis of functional magnetic and Janus nanobeads', Langmuir, 28: 9748-9758.

Chatterjee, S. and Judeh, Z.M.A. (2015) 'Encapsulation of fish oil with N-stearoyl Obutylglyceryl chitosan using membrane and ultrasonic emulsification processes', Carbohydr. Polym., 123: 432-442.

Chen, G.G., Luo, G.S., Sun, Y., Xu, J.H. and Wang, J.D. (2004) 'A ceramic microfiltration tube membrane dispersion extractor', AIChE J., 50: 382-387.

Cheng, C.J., Chu, L.Y., Xie, R. and Wang, X.W. (2008) 'Preparation of highly monodisperse W/O emulsions with hydrophobically modified SPG membranes', Chem. Eng. Technol., 31: 377-383.

Chevalier, Y. and Bolzinger, M.A. (2013) 'Emulsions stabilized with solid nanoparticles: Pickering emulsions', Colloids Surf., A, 439, 23-34.

Cho, Y.H., Lee, J.J., Park, I.B., Huh, C.S., Baek, Y.J. and Park, J. (2005) 'Protective effect of microencapsulation consisting of multiple emulsification and heat gelation processes on immunoglobulin in yolk', J. Food Sci., 70: E148-E151.

Choi, Y.K., Poudel, B.K., Marasini, N., Yang, K.Y., Kim, J.W., Kim, J.O., Choi, H.G. and Yong, C.S. (2012) 'Enhanced solubility and oral bioavailability of itraconazole by combining membrane emulsification and spray drying technique', Int. J. Pharm., 434: 264-271. 
Choi, D.Y. Jung, S.W., Kim, T.J. and Lee, S.J. (2014) 'A prototype of time temperature integrator (TTI) with microbeads-entrapped microorganisms maintained at a constant concentration', J. Food Eng., 120: 118-123.

Chu, L.Y., Park, S.H., Yamaguchi, T. and Nakao S. (2002) 'Preparation of micron-sized monodispersed thermoresponsive core-shell microcapsules', Langmuir, 18: 1856-1864.

Chu, L.Y., Park, S.H., Yamaguchi, T. and Nakao, S. (2003) 'Study of SPG membrane emulsification processes for the preparation of monodisperse core-shell microcapsules', $J$. Membr. Sci., 192: 27-39.

Cosgrove, D. (2006) 'Ultrasound contrast agents: An overview’, Eur. J. Radiol., 60: 324-330. van Dijke, K, Kobayashi, I., Schroën, K., Uemura, K., Nakajima, M. and Boom, R. (2010) 'Effect of viscosities of dispersed and continuous phases in microchannel oil-in-water emulsification’, Microfluid. Nanofluid., 9: 77-85.

Destribats, M., Wolfs, M., Pinaud, F., Lapeyre, V., Sellier, E., Schmitt, V. and Ravaine, V. (2013) 'Pickering emulsions stabilized by soft microgels: Influence of the emulsification process on particle interfacial organization and emulsion properties', Langmuir, 29: $12367-12374$.

Dinsmore, A.D., Ming F.H., Nikolaides, M.G., Marquez, M., Bausch, A.R. and Weitz, D.A. (2005) 'Colloidosomes: selectively permeable capsules composed of colloidal particles', Science, 298: 1006-1009.

Doan, T.V.P., Couet, W. and Olivier, J.C. (2011) 'Formulation and in vitro characterization of inhalable rifampicin-loaded PLGA microspheres for sustained lung delivery', Int. J. Pharm., 414: 112-117.

Dowding, P.J., Goodwin, J.W. and Vincent, B. (2001) 'Production of porous suspension polymer beads with a narrow size distribution using a cross-flow membrane and a continuous tubular reactor', Colloid. Surf. A, 180: 310-309.

D’oria, C., Charcosset, C., Barresi, A.A. and Fessi, H. (2009) 'Preparation of solid lipid particles by membrane emulsification-Influence of process parameters', Colloids Surf., A, 338: 114-118.

Dragosavac, M.M., Holdich, R.G., Vladisavljević, G.T. and Sovilj, M.N. (2012) 'Stirred cell membrane emulsification for multiple emulsions containing unrefined pumpkin seed oil with uniform droplet size’, J. Membr. Sci., 392-393: 122-129. 
Dragosavac, M.M., Vladisavljević, G.T., Holdich, R.G. and Stillwell, M.T. (2012b) 'Production of porous silica microparticles by membrane emulsification', Langmuir, 28: 134143.

Dragosavac, M.M., Vladisavljević, G.T., Holdich, R.G. and Stillwell, M.T. (2012c) 'Novel membrane emulsification method of producing highly uniform silica particles using inexpensive silica sources’, Prog. Colloid Polym. Sci., 139, 7-11.

Egidi, E., Gasparini, G., Holdich, R.G., Vladisavljević, G.T. and Kosvintsev, S.R. (2008) 'Membrane emulsification using membranes of regular pore spacing: Droplet size and uniformity in the presence of surface shear', J. Membr. Sci., 323: 414-420.

El-Khatat, A.M. and Al-Muhtaseb, S.A. (2011) 'Advances in tailoring resorcinolformaldehyde organic and carbon gels', Adv. Mater., 23: 2887-2903.

El-Mahdy, M., Ibrahim, E.S., Safwat, S., el-Sayed, A., Ohshima, H., Makino, K., Muramatsu, N. and Kondo, T. (1998) 'Effects of preparation conditions on the monodispersity of albumin microspheres', J. Microencapsulation, 15: 661-673.

Gasparini, G., Kosvintsev, S.R., Stillwell, M.T. and Holdich, R.G. (2008) 'Preparation and characterization of PLGA particles for subcutaneous controlled drug release by membrane emulsification’, Colloids Surf., B, 61: 199-207.

Geerken, M.J. (2006) ‘Emulsification with micro-engineered devices’, PhD Thesis,

University of Twente.

Geerken, M.J., Lammertink, R.G.H. and Wessling, M. (2007) 'Interfacial aspects of water drop formation at micro-engineered orifices’, J. Colloid Interface Sci., 312: 460-469.

van der Graaf, S., Schroën, C.G.P.H., Van der Sman, R.G.M. and Boom, R.M. (2004) 'Influence of dynamic interfacial tension on droplet formation during membrane emulsification', J. Colloid Interface Sci., 277: 456-463.

van der Graaf, S., Steegmans, M.L.J., van der Sman, R.G.M., Schroën, C.G.P.H. and Boom, R.M. (2005) 'Droplet formation in a T-shaped microchannel junction: A model system for membrane emulsification’, Colloid. Surf. A, 266: 106-116.

van der Graaf, S., Nisisako, T., Schroën, C.G.P.H., van der Sman, R.G.M. and Boom, R.M. (2006) 'Lattice Boltzmann simulations of droplet formation in a T-shaped microchannel', Langmuir, 22: 4144-4152.

Geerken, M.J., Groenendijk, M.N.W., Lammertink, R.G.H. and Wessling, M. (2008) 'Microfabricated metal nozzle plates used for water-in-oil and oil-in-water emulsification', J. Membr. Sci., 310: 374-383. 
Gomaa, H.G., Liu, J., Sabouni, R. and Zhu, J. (2014) 'Experimental and theoretical analysis of emulsification characteristics using a high porosity microscreen under oscillatory shear conditions', Colloid. Surf. A, 456: 160-168.

Gudipati, V., Sandra, S., McClements, D.J. and Decker, E.A. (2010) 'Oxidative stability and in vitro digestibility of fish oil-in-water emulsions containing multilayered membranes', $J$. Agric. Food Chem., 58: 8093-8099.

Han, S.W., Jang, E. and Koh, W.G. (2015) 'Microfluidic-based multiplex immunoassay system integrated with an array of QD-encoded microbeads', Sens. Actuators, B, 209: 242251.

Hanga, M.P. and Holdich, R.G. (2014) 'Membrane Emulsification for the production of uniform poly-N-isopropylacrylamide-coated alginate particles using internal gelation', Ind. Eng. Chem. Res., 92: 1664-1673.

Hao, D.X., Gong, F.L., Hu, G.H., Lei, J.D., Ma, G.H. and Su, Z.G. (2009) 'The relationship between heterogeneous structures and phase separation in synthesis of uniform PolyDVB microspheres', Polymer, 50: 3188-3195.

Higashi, S. and Setoguchi, T. (2000) 'Hepatic arterial injection chemotherapy for hepatocellular carcinoma with epirubicin aqueous solution as numerous vesicles in iodinated poppy-seed oil microdroplets: clinical application of water-in-oil-in-water emulsion prepared using a membrane emulsification technique’, Adv. Drug Deliv. Rev., 45: 57-64.

Hoare, T.R. and Kohane, D.S. (2008) 'Hydrogels in drug delivery: Progress and challenges', Polymer, 49: 1993-2007.

Holdich, R.G., Dragosavac, M.M., Vladisavljević, G.T. and Kosvintsev, S.R. (2010) 'Membrane emulsification with oscillating and stationary membranes', Ind. Eng. Chem. Res., 49: 3810-3817.

Holdich, R.G., Ipek, I.Y., Lazrigh, M. and Shama, G. (2012) 'Production and evaluation of floating photocatalytic composite particles formed using Pickering emulsions and membrane emulsification', Ind. Eng. Chem. Res., 51: 12509-12516.

Holdich, R.G., Dragosavac, M., Vladisavljević, G.T. and Piacentini, E. (2013) 'Continuous membrane emulsification with pulsed (oscillatory) flow', Ind. Eng. Chem. Res., 52: 507-515. Holzapfel, S., Rondeau, E., Mühlich, P. and Windhab, E.J. (2013) 'Drop detachment from a micro-engineered membrane surface in a dynamic membrane emulsification process', Chem. Eng. Technol., 36: 1785-1794.

Hou, Z., Lin, C. and Zhang, Q. (2009) 'Preparation and characterization of PLA ultrasound 
contrast agents by combining an ultrasound method and a Shirasu Porous Glass (SPG) membrane emulsification technique', 3rd International Conference on Bioinformatics and Biomedical Engineering, 2009. ICBBE 2009.

Hu, J., Hiwatashi, K., Kurokawa, T., Liang, S.M., Wu, Z.L. and Gong, J.P. (2011) 'Microgelreinforced hydrogel films with high mechanical strength and their visible mesoscale fracture structure', Macromolecules, 44: 7775-7781.

Hwang, T., Park, T.J., Koh, W.G., Cheong, I.W., Choi, S.W. and Kim, J.H. (2011) 'Fabrication of nano-scale liposomes containing doxorubicin using Shirasu porous glass membrane', Colloids Surf., A, 392: 250-255.

Imbrogno, A., Piacentini, E., Drioli, E. and Giorno, L. (2014) 'Preparation of uniform polycaprolactone microparticles by membrane emulsification/solvent diffusion process', $J$. Membr. Sci., 467: 262-268.

Imbrogno, A., Dragosavac, M.M., Piacentini E., Vladisavljević, G.T., Holdich R.G. and Giorno, L. (2015) 'Polycaprolactone multicore-matrix particle for the simultaneous encapsulation of hydrophilic and hydrophobic compounds produced by membrane emulsification and solvent diffusion processes', Colloids Surf., $B$, in press.

Ito, F. and Makino, K. (2004) 'Preparation and properties of monodispersed rifampicinloaded poly(lactide-co-glycolide) microspheres’, Colloids Surf., B, 39: 17-21.

Ito, F., Uchida, Y. and Murakami, Y. (2010) 'Facile technique for preparing organicinorganic composite particles: Monodisperse poly(lactide-co-glycolide) (PLGA) particles having silica nanoparticles on the surface’, Colloids Surf., A, 361: 109-117.

Ito, F., Kanakubo, Y. and Murakami, Y. (2011) 'Rapid preparation of monodisperse biodegradable polymer nanospheres using a membrane emulsification technique under low gas pressure’, J. Polym. Res., 18: 2077-2085.

Jing, C., Chin, C.Y. and Xie, R. (2006) 'Preparation of highly monodisperse W/O emulsions with hydrophobically modified SPG membranes', J. Colloid Interface Sci., 300: 375-382.

Joscelyne, S.M. and Trägårdh, G. (2000) 'Membrane emulsification - a literature review', J. Membr. Sci., 169: 107-117.

Kage, H., Kawahara, H., Ogura, H. and Matsuno, Y. (1997) 'Microencapsulation of monodispersed droplets by complex coacervation method and membrane thickness of generated capsules’, Kagaku Kogaku Ronbunshu, 23: 652-658.

Kai, T., Suma, Y., Ono, S., Yamaguchi and Nakao, S. (2006) 'Effect of the pore surface modification of an inorganic substrate on the plasma-grafting behavior of pore-filling-type 
organic/inorganic composite membranes', J. Polym. Sci., Part A-1: Polym. Chem., 44: 846-856.

Kakazu, E., Murakami, T., Akamatsu, K., Sugawara, T., Kikuchi, R. and Nakao, S. (2010) 'Preparation of silver nanoparticles using the SPG membrane emulsification technique', $J$. Membr. Sci., 354: 1-5.

Kanakubo, Y., Ito, F. and Murakami, Y. (2010) 'Novel one-pot facile technique for preparing nanoparticles modified with hydrophilic polymers on the surface via block polymer-assisted emulsification/evaporation process', Colloids Surf., B, 78: 85-91.

Kandori, K., Kishi, K. and Ishikawa T. (1992) 'Preparation of uniform silica hydrogel particles by SPG filter emulsification method', Colloids Surf., 62: 259-262.

Karbstein, H. and Schubert H. (1995) 'Developments in the continuous mechanical production of oil-water macro-emulsions', Chem. Eng. Process., 34: 205-211.

Kawakita, H., Hamamoto, K., Seto, H., Ohto, K., Harada, H. and Inoue, K. (2009) 'Porosity estimation of a membrane filled with dextran produced by immobilized dextransucrase', AIChE J., 55: 275-278.

Kazazi-Hyseni, F., Landin, M., Lathuile, A., Veldhuis, G.J., Rahimian, S., Hennink, W.E., Kok, R.J. and van Nostrum, C.F. (2014) 'Computer modeling assisted design of monodisperse PLGA microspheres with controlled porosity affords zero order release of an encapsulated macromolecule for 3 months', Pharm. Res., 10: 2844-2856.

Kazazi-Hyseni, F., van Vuuren, S.H., van der Giezen, D.M., Pieters, E.H., Ramazani, F., Rodriguez, S., Veldhuis, G.J., Goldschmeding, R., van Nostrum, C.F., Hennink, W.E. and Kok, R.J. (2015) 'Release and pharmacokinetics of near-infrared labeled albumin from monodisperse poly(D,L-lactic-co-hydroxymethyl glycolic acid) microspheres after subcapsular renal injection', Acta Biomaterialia, 22: 141-154.

Klibanov, A.L. (2007) 'Ultrasound molecular imaging with targeted microbubble contrast agents’, J. Nucl. Cardiol., 14: 876-884.

Kobayashi, I., Nakajima, M., Chun, K., Kikuchi, Y. and Fujita, H. (2002) 'Silicon array of elongated through-holes for monodisperse emulsion droplets', AIChE J., 48: 1639-1644.

Kobayashi, I., Nakajima, M. and Mukataka, S. (2003) 'Preparation characteristics of oil-inwater emulsions using differently charged surfactants in straight-through microchannel emulsification', Colloid. Surf. A, 229: 33-41. 
Kobayashi, I., Mukataka, S. and Nakajima, M. (2004) 'Effect of slot aspect ratio on droplet formation from silicon straight-through microchannels', J. Colloid Interface Sci., 279: 277-280.

Kobayashi, I., Mukataka, S. and Nakajima, M. (2005) 'Production of monodisperse oil-inwater emulsions using a large silicon straight-through microchannel plate', Ind. Eng. Chem. Res., 44: 5852-5856.

Kobayashi, I., Mukataka, S. and Nakajima, M. (2005b) 'Novel asymmetric through-hole array microfabricated on a silicon plate for formulating monodisperse emulsions', Langmuir, 21: 7629-7632.

Kobayashi, I., Wada, Y., Uemura, K. and Nakajima, M. (2008) 'Generation of uniform drops via through-hole arrays micromachined in stainless-steel plates', Microfluid. Nanofluid., 5: 677-687.

Kobayashi, I., Hirose, S., Katoh, T., Zhang, Y., Uemura, K. and Nakajima, M. (2008b) 'Highaspect-ratio through-hole array microfabricated in a PMMA plate for monodisperse emulsion production’, Microsyst. Technol., 14: 1349-1357.

Kobayashi, Y. Murayama, T. Kuroiwa, K. Uemura, M. and Nakajima, M. (2009) 'Production of monodisperse water-in-oil emulsions consisting of highly uniform droplets using asymmetric straight-through microchannel arrays’, Microfluid. Nanofluid., 7: 107-119.

Kobayashi, I., Murayama, Y., Kuroiwa, T., Uemura, K. and Nakajima, M. (2009b) 'Production of monodisperse water-in-oil emulsions consisting of highly uniform droplets using asymmetric straight-through microchannel arrays', Microfluid. Nanofluid., 7: 107-119. Koga, K., Takarada, N. and Takada, K. (2010) 'Nano-sized water-in-oil-in-water emulsion enhances intestinal absorption of calcein, a high solubility and low permeability compound', Eur. J. Pharm. Biopharm., 74: 223-232.

Kobayashi, I., Vladisavljević, G.T., Uemura, K. and Nakajima, M (2011) 'CFD analysis of microchannel emulsification: Droplet generation process and size effect of asymmetric straight flow-through microchannels', Chem. Eng. Sci., 66: 5556-5565.

Koltuniewicz, A.B., Field, R.W. and Arnot, T.C. (1995) 'Cross-flow and dead-end microfiltration of oily-water emulsion. Part I: Experimental study and analysis of flux decline’, J. Membr. Sci., 102: 193-207.

Kong, S.D., Zhang, W., Lee, J.H., Brammer, K., Lal, R., Karin, M. and Jin, S. (2010) 'Magnetically vectored nanocapsules for tumor penetration and remotely switchable ondemand drug release', Nano Lett., 10: 5088-5092. 
Kong, S.D., Zhang, W., Lee, J.H., Choi, C., Khamwannah, J., Karin, M. and Jin, S. (2012) 'Externally triggered on-demand drug release and deep tumor penetration', J. Vac. Sci. Technol., B: Microelectron. Nanometer Struct., 30: 02C102-02C102-7.

Kong, S.D., Choi, C., Khamwannah, J. and Jin, S. (2013) 'Magnetically vectored delivery of cancer drug using remotely on-off switchable nanocapsules', IEEE Trans. Magn., 49: 349-352.

Koris, A., Piacentini, E., Vatai, G., Bekassy-Molnar, E., Drioli, E. and Giorno, L. (2011) 'Investigation on the effects of a mechanical shear-stress modification method during crossflow membrane emulsification', J. Membr. Sci., 371: 28-36.

Kosvintsev, S.R., Gasparini, G., Holdich, R.G., Cumming, I.W. and Stillwell, M.T. (2005) 'Liquid-liquid membrane dispersion in a stirred cell with and without controlled shear', Ind. Eng. Chem. Res., 44: 9323-9330.

Kosvintsev, S.R., Gasparini, G. and Holdich, R.G. (2008) 'Membrane emulsification: droplet size and uniformity in the absence of surface shear', J. Membr. Sci., 313: 182-189.

Kou, X., Li, Q., Lei, J., Geng, L., Deng, H., Zhang, G., Ma, G., Su, Z. amd Jiang, Q. (2012) 'Preparation of molecularly imprinted nanospheres by premix membrane emulsification technique', J. Membr. Sci., 417-418: 87-95.

Kukizaki, M. and Nakashima, T. (2004) 'Acid leaching process in the preparation of porous glass membranes from phase-separated glass in the $\mathrm{Na}_{2} \mathrm{O}-\mathrm{CaO}-\mathrm{MgO}-\mathrm{Al}_{2} \mathrm{O}_{3}-\mathrm{B}_{2} \mathrm{O}_{3}-\mathrm{SiO}_{2}$ system’, Membrane, 29: 301-308.

Kukizaki, M. and Goto, M. (2006) 'Size control of nanobubbles generated from Shirasuporous-glass (SPG) membranes’, J. Membr. Sci., 281: 386-396.

Kukizaki, M. and Goto, M. (2007) 'Spontaneous formation behavior of uniform-sized microbubbles from Shirasu porous glass (SPG) membranes in the absence of water-phase flow’, Colloids Surf., A, 296: 174-181.

Kukizaki, M. and Goto, M. (2007b) 'Preparation and characterization of a new asymmetric type of Shirasu porous glass (SPG) membrane used for membrane emulsification', J. Membr. Sci., 299: 190-199.

Kukizaki, M. and Goto, M. (2007c) 'Preparation and evaluation of uniformly sized solid lipid microcapsules using membrane emulsification’, Colloids Surf., A, 293: 87-94.

Kukizaki, M. and Goto, M. (2008) 'Demulsification of water-in-oil emulsions by permeation through Shirasu-porous-glass (SPG) membranes’, J. Membr. Sci., 322: 196-203. 
Kukizaki, M. and Goto, M. (2009) 'A comparative study of SPG membrane emulsification in the presence and absence of continuous-phase flow', J. Chem Eng. Jpn, 42: 520-530.

Kukizaki, M. (2009) 'Shirasu porous glass (SPG) membrane emulsification in the absence of shear flow at the membrane surface: Influence of surfactant type and concentration, viscosities of dispersed and continuous phases, and transmembrane pressure', J. Membr. Sci., 327: 234-243.

Kukizaki, M. (2009b) 'Relation between salt rejection and electrokinetic properties on Shirasu porous glass (SPG) membranes with nano-order uniform pores', Sep. Sci. Technol., 69: 87-96.

Kukizaki, M. (2009c) 'Preparation of solid lipid microcapsules via solid-in-oil-in-water dispersions by premix membrane emulsification’, Chem. Eng. J., 151: 387-396.

Kukizaki, M. (2010) 'Large-scale production of alkali-resistant Shirasu porous glass (SPG) membranes: Influence of $\mathrm{ZrO}_{2}$ addition on crystallization and phase separation in $\mathrm{Na}_{2} \mathrm{O}-$ $\mathrm{CaO}-\mathrm{Al}_{2} \mathrm{O}_{3}-\mathrm{B}_{2} \mathrm{O}_{3}-\mathrm{SiO}_{2}$ glasses; and alkali durability and pore morphology of the membranes', J. Membr. Sci., 360: 426-435.

Lai, Y.T., Sato, M., Ohta, S., Akamatsu, K., Nakao, S., Sakai, Y. and Ito, T. (2015) 'Preparation of uniform-sized hemoglobin-albumin microspheres as oxygen carriers by Shirasu porous glass membrane emulsification technique’, Colloids Surf., B, 127: 1-7.

Lee, S.H., Baek, H.H., Kim, J.H. and Choi, S.W. (2009) 'Core-shell poly(d,l-lactide-coglycolide)/poly(ethyl 2-cyanoacrylate) microparticles with doxorubicin to reduce initial burst release’, Macromol. Res., 17: 1010-1014.

Lee, J., Hwang, D.R. and Shim, S.E. (2010) 'Controlling morphology of polymer microspheres by Shirasu porous glass (SPG) membrane emulsification and subsequent polymerization: from solid to hollow’, Macromol. Res., 18: 1142-1147.

Li, N. and Sakaki, K. (2008) 'Performance of an emulsion enzyme membrane reactor combined with premix membrane emulsification for lipase-catalyzed resolution of enantiomers', J. Membr. Sci., 314: 183-192.

Li, Y., Fessi, H. and Charcosset, C. (2011) 'Preparation of indomethacin-loaded lipid particles by membrane emulsification’, Adv. Sci. Lett., 4: 591-595.

Li, Y. and McClements, D.J. (2014) 'Modulating lipid droplet intestinal lipolysis by electrostatic complexation with anionic polysaccharides: Influence of cosurfactants', Food Hydrocolloids, 35: 367-374. 
Liu, X.D., Bao, D.C., Xue, W.M., Xiong, Y., Yu, W.T., Yu, X.J., Ma, X.J. and Yuan, Q. (2003) 'Preparation of uniform calcium alginate gel beads by membrane emulsification coupled with internal gelation', J. Appl. Polym. Sci., 87: 848-852.

Liu, R., Ma, G.H., Meng, F.T. and Su, Z.G. (2005) 'Preparation of uniform-sized PLA microcapsules by combining Shirasu Porous Glass membrane emulsification technique and multiple emulsion-solvent evaporation method', J. Controlled Release, 103: 31-43.

Liu, R., Ma, G.H., Wan, Y.H. and Su, Z.G. (2005b) 'Influence of process parameters on the size distribution of PLA microcapsules prepared by combining membrane emulsification technique and double emulsion-solvent evaporation method', Colloids Surf., B, 45: 144-153.

Liu, R., Huang, S.S., Wan, Y.H., Ma, G.H. and Su, Z.G. (2006) 'Preparation of insulin-loaded PLA/PLGA microcapsules by a novel membrane emulsification method and its release in vitro', Colloids Surf., B, 51: 30-38.

Liu, Y., Feng, X.J., Bao, D.C., Li, K.X. and Bao, M. (2010) 'Preparation of microcapsulesupported palladium catalyst using SPG (Shirasu Porous Glass) emulsification technique', Chin. Chem. Lett., 21: 979-982.

Liu, Y., Feng, X.J., Bao, D.C., Li, K. and Bao, M. (2010b) 'A new method for the preparation of microcapsule-supported palladium catalyst for Suzuki coupling reaction', J. Mol. Catal. A: Chem., 323: 16-22.

Liu, X., Lee, J.K. and Kessler, M.R. (2011) 'Microencapsulation of self-healing agents with melamine-urea-formaldehyde by the Shirasu porous glass (SPG) emulsification technique', Macromol. Res., 19: 1056-1061.

Liu, B., Zhou, X., Yang, F., Shen, H., Wang, S., Zhang, B., Zhi, G. and Wu, D. (2014) 'Fabrication of uniform sized polylactone microcapsules by premix membrane emulsification for ultrasound imaging', Polym. Chem., 5: 1693-1701.

Laouini, A., Fessi, H. and Charcosset, C. (2012) 'Membrane emulsification: A promising alternative for vitamin E encapsulation within nano-emulsion', J. Membr. Sci., 423-424: 85-96.

Laouini, A., Charcosset, C., Fessi, H., Holdich, R.G. and Vladisavljević, G.T. (2013) 'Preparation of liposomes: a novel application of microengineered membranes: From laboratory scale to large scale', Colloids Surf. B, 112: 272-278.

Laouini, A., Charcosset, C., Fessi, H. and Schroen, K. (2014) 'Use of dynamic membranes for the preparation of vitamin E-loaded lipid particles: An alternative to prevent fouling observed in classical cross-flow emulsification', Chem. Eng. J., 236: 498-505. 
Li, Q., Zhang, R., Li, J., Yan, X., Wang, L., Gong, F., Su, Z. and Ma, G. (2013) 'In situ inhibitor $(\mathrm{HCl})$ removal promoted heterogeneous Friedel-Crafts reaction of polystyrene microsphere with Lewis acids catalysts ‘, J. Mol. Catal. A: Chem., 370: 56-63.

Loxley, A. and Vincent, B. (1998) 'Preparation of poly(methylmethacrylate) microcapsule with liquid cores', J. Colloid Interface Sci., 208: 49-62.

Lv, P.P., Wei, W., Gong, F.L., Zhang, Y.L., Zhao, H.Y., Lei, J.D., Wang, L.Y. and Ma, G.H. (2009) 'Preparation of uniformly sized chitosan nanospheres by a premix membrane emulsification technique’. Ind. Eng. Chem. Res., 48: 8819-8828.

Ma, G.H., Nagai, M. and Omi, S. (1999) 'Study on preparation and morphology of uniform artificial polystyrene-poly(methyl methacrylate) composite microspheres by employing the SPG (Shirasu Porous Glass) membrane emulsification technique', J. Colloid Interface Sci., 214: 264-282.

Ma, G.H., Nagai, M. and Omi, S. (1999b) 'Effect of lauryl alcohol on morphology of uniform polystyrene-poly(methyl methacrylate) composite microspheres prepared by Porous glass membrane emulsification technique’, J. Colloid Interface Sci., 219: 110-128.

Ma, G.H., Nagai, M. and Omi, S. (1999c) 'Preparation of uniform poly(lactide) microspheres by employing the shirasu porous glass (SPG) emulsification technique', Colloids Surf. A, 153: 383-394.

Ma, G.H., Nagai, M. and Omi, S. (2001) 'Study on preparation of monodispersed poly(styrene-co-N-dimethylaminoethyl methacrylate) composite microspheres by SPG (shirasu porous glass) emulsification technique', J. Appl. Polym. Sci., 79: 2408-2424.

Ma, G.H., Omi, S., Dimonie, V.L., Sudol, E.D. and El-Aasser, M.S. (2002) 'Study of the preparation and mechanism of formation of hollow monodisperse polystyrene microspheres by SPG (Shirasu Porous Glass) emulsification technique', J. Appl. Polym. Sci., 85: 1530-1543.

Ma, G.H., An, C.J., Yuyama, H., Su, Z.G. and Omi, S. (2003) 'Synthesis and characterization of polyurethaneurea-vinyl polymer (PUU-VP) uniform hybrid microspheres by SPG emulsification technique and subsequent suspension polymerization', J. Appl. Polym. Sci., 89: 163-178.

Ma, G.H., Chen, A.Y., Su, Z.G. and Omi, S. (2003b) 'Preparation of uniform hollow polystyrene particles with large voids by a glass-membrane emulsification technique and a subsequent suspension polymerization’, J. Appl. Polym. Sci., 87: 244-251. 
Ma, G.H., Su, Z.G., Omi, S., Sundberg, D. and Stubbs, J. (2003c) 'Microencapsulation of oil with poly(styrene-N,N-dimethylaminoethyl methacrylate) by SPG emulsification technique: Effects of conversion and composition of oil phase’, J. Colloid Interface Sci., 266: 282-294.

Ma, G.H., Sone, H. and Omi, S. (2004) 'Preparation of uniform-sized polystyrenepolyacrylamide composite microspheres from a W/O/W emulsion by membrane emulsification technique and subsequent suspension polymerization', Macromolecules, 37: $2954-2964$.

Ma, G.H., Yang, J., Lv, P.P., Wang, L.Y., Wei, W., Tian, R., Wu, J. and Su, Z.G. (2010) 'Preparation of uniform microspheres and microcapsules by modified emulsification process' Macromol. Symp., 288: 41-48.

Ma, T., Wang, L., Yang, T., Wang, D., Ma, G. and Wang, S. (2014) 'PLGA-lipid liposphere as a promising platform for oral delivery of proteins', Colloids Surf. B, 117: 512-519.

Ma, T., Wang, L., Yang, T., Ma, G. and Wang, S. (2014b) 'M-cell targeted polymeric lipid nanoparticles containing a toll-like receptor agonist to boost oral immunity’, Int. J. Pharm., 473: 296-303.

Ma, T., Wang, L., Yang, T., Ma, G. and Wang, S. (2014c) 'Homogeneous PLGA-lipid nanoparticle as a promising oral vaccine delivery system for ovalbumin', Asian J. Pharm. Sci., 9: $129-136$.

Maan, A.A., Schroën, K. and Boom, R. (2011) 'Spontaneous droplet formation techniques for monodisperse emulsions preparation - Perspectives for food applications', J. Food Eng., 107: 334-346.

Manga, M.S., Cayre, O.J., Williams, R.A., Biggs, S. and York, D.W. (2012) 'Production of solid-stabilised emulsions through rotational membrane emulsification: influence of particle adsorption kinetics', Soft Matter, 8, 1532-1538.

Matos, M., Gutiérrez, G., Iglesias, O., Coca, J. and Pazos, C. (2015) 'Characterization, stability and rheology of highly concentrated monodisperse emulsions containing lutein', Food Hydrocolloids, 49: 156-163.

Mazzei, R., Drioli, E. and Giorno, L. (2010) 'Biocatalytic membrane reactor and membrane emulsification concepts combined in a single unit to assist production and separation of water unstable reaction products', J. Membr. Sci., 352: 166-172.

McClements, D.J. (2005) 'Food Emulsions: Principles, Practices, and Techniques', CRC Press, Boca Raton, 2005.

McClements, D.J., Decker, E.A. and Weiss J. (2007) 'Emulsion-based delivery systems for 
lipophilic bioactive components’, J. Food Sci., 72: R109-R124.

McClements, D.J. (2015) 'Encapsulation, protection, and release of hydrophilic active components: Potential and limitations of colloidal delivery systems', Adv. Colloid Interface Sci., 219: 27-53.

Meng, T., Xie, R., Chen, Y.C., Cheng, C.J., Li, P.F., Ju, X.J. and Chu, L.Y. (2010) 'A thermo-responsive affinity membrane with nano-structured pores and grafted poly $(\mathrm{N}-$ isopropylacrylamide) surface layer for hydrophobic adsorption', J. Membr. Sci., 349: $258-267$.

Meng, T., Xie, R., Ju, X.J., Cheng, C.J., Wang, S., Li, P.F., Liang, B. and Chun, L.Y. (2013) 'Nano-structure construction of porous membranes by depositing nanoparticles for enhanced surface wettability', J. Membr. Sci., 427: 63-72.

Meyer, R.F., Rogers, W.B., McClendon, M.T. and Crocker, J.C. (2010) 'Producing monodisperse drug-loaded polymer microspheres via cross-flow membrane emulsification: the effects of polymers and surfactants', Langmuir, 26, 14479-14487.

Mi, Y., Zhou, W., Li, Q., Gong, F., Zhang, R., Ma, G., Su, Z. (2015) 'Preparation of water-inoil emulsions using a hydrophobic polymer membrane with 3D bicontinuous skeleton structure’, J. Membr. Sci., 490: 113-119.

Moreno-Castilla, C. and Maldonado-Hódar, F.J. (2005) 'Carbon aerogels for catalysis applications: An overview’, Carbon, 43: 455-465.

Muramatsu, N. and Kondo, T. (1995) 'An approach to prepare microparticles of uniform size’, J. Microencapsulation, 2: 129-136.

Muramatsu, N. and Nakauchi, K. (1998) 'A novel method to prepare monodisperse microparticles', J. Microencapsulation, 15: 715-723.

Nagashima, S., Ando, S., Tsukamoto, T., Ohshima, H. and Makino, K. (1998) 'Preparation of monodisperse poly(acrylamide-co-acrylic acid) hydrogel microspheres by a membrane emulsification technique and their size-dependent surface properties', Colloids Surf., B, 11: 47-56.

Nakashima, T. and Kuroki, Y. (1981) 'Effect of composition and heat treatment on the phase separation of $\mathrm{NaO}-\mathrm{B}_{2} \mathrm{O}_{3}-\mathrm{SiO}_{2}-\mathrm{Al}_{2} \mathrm{O}_{3}-\mathrm{CaO}$ glass prepared from volcanic ashes', Nippon Kagaku Kaishi, 8: 1231-1238.

Nakashima T. and Shimizu M. (1986) 'Porous glass from calcium alumino boro-silicate glass’, Ceramics Japan, 21: 408-412. 
Nakashima T., Shimizu M. and Kukizaki, M. (1991) 'Membrane emulsification by microporous glass', Key Eng. Mater., 61-62: 513-516.

Nakashima, T., Shimizu, M. and Kukizaki M. (1992) 'Mechanical strength and thermal resistance of porous glass', J. Ceram. Soc. Jpn. Int. Ed., 100: 1389-1393.

Nakashima, T., Shimizu, M. and Kukizaki M. (1993) 'Effect of surfactant on production of monodispersed O/W emulsion in membrane emulsification', Kag. Kog. Ronbunshu, 19: 991-997.

Nakashima, T., Shimizu, M. and Kukizaki M. (1994) 'Monodisperse single and double emulsions and method of producing same’, US Patent 5,326,484.

Nakashima, T., Shimizu, M. and Kukizaki, M. (2000) 'Particle control of emulsion by membrane emulsification and its applications', Adv. Drug Deliv. Rev., 45: 47-56.

Nakashima, T. (2002) 'Porous glass material and its recent applications', paper presented at $38^{\text {th }}$ International SPG Forum on Membrane and Particle Science and Technology in Food and Medical Care in Sadowara, Japan.

Nan, F., Wu, J., Qi, F., Liu, Y., Ngai T. and Ma, G. (2014) 'Uniform chitosan-coated alginate particles as emulsifiers for preparation of stable Pickering emulsions with stimulus dependence', Colloids Surf., A, 456: 246-252.

Nan, F., Wu, J., Qi, F., Fan, Q., Ma, G. and Ngai, T. (2014b) 'Preparation of uniform-sized colloidosomes based on chitosan-coated alginate particles and its application for oral insulin delivery’, J. Mater. Chem. B, 2: 7403-7409.

Nazir, A., Schroën, K. and Boom, R. (2010) 'Premix emulsification: A review', J. Membr. Sci., 362: 1-11.

Nazir, A., Schroën, K. and Boom, R. (2011) 'High-throughput premix membrane emulsification using nickel sieves having straight-through pores', J. Membr. Sci., 383: 116123.

Nazir, H., Wang, L., Lian, G., Zhu, S., Zhang, Y., Liu, Y. and Ma, G. (2012) 'Multilayered silicone oil droplets of narrow size distribution: Preparation and improved deposition on hair', Colloids Surf., B, 100: 42-49.

Nazir, A., Schroën, K. and Boom, R. (2013) 'The effect of pore geometry on premix membrane emulsification using nickel sieves having uniform pores', Chem. Eng. Sci., 93: $173-180$. 
Nuisin, R., Ma, G.H., Omi, S. and Kiatkamjornwong, S.J. (2000) 'Dependence of morphological changes of polymer particles on hydrophobic/hydrophilic additives', J. Appl. Polym. Sci., 77: 1013-1028.

Ogończyk, D., Siek, M. and Garstecki, P. (2011) 'Microfluidic formulation of pectin microbeads for encapsulation and controlled release of nanoparticles', Biomicrofluidics, 5: 013405.

Oh, D.H., Balakrishnan, P., Oh, Y.K., Kim, D.D., Yong, C.S. and Choi, H.G. (2011) 'Effect of process parameters on nanoemulsion droplet size and distribution in SPG membrane emulsification', Int. J. Pharm., 404: 191-197.

Oh, D.H., Din, F.U., Kim, D.W., Kim, J.O., Yong, C.S. and Choi, H.G. (2013) 'Flurbiprofenloaded nanoparticles prepared with polyvinylpyrrolidone using Shirasu porous glass membranes and a spray-drying technique: nano-sized formation and improved bioavailability', J. Microencapsulation, 30: 674-680.

Olson, F., Hunt, C.A. and Szoka, F.C. (1979) 'Preparation of liposomes of defined size distribution by extrusion through polycarbonate membranes', Biochim. Biophys. Acta, 557: 9-23.

Omi, S., Katami, K., Yamamoto, A. and Iso, M. (1994) 'Synthesis of polymeric microspheres employing SPG emulsification technique’, J. Appl. Polym. Sci., 51: 1-11.

Omi, S., Katami, K., Taguchi, T., Kaneko, K. and Iso, M. (1995) 'Synthesis of uniform PMMA microspheres employing modified SPG (Shirasu Porous Glass) emulsification technique', J. Appl. Polym. Sci., 57: 1013-1024.

Omi, S., Taguchi, T, Nagai, M. and Ma, G.H. (1997) 'Synthesis of $100 \mu \mathrm{m}$ uniform porous spheres by SPG emulsification with subsequent swelling of the droplets', J. Appl. Polym. Sci., 63: 931-942.

Omi, S., Ma, G.H. and Nagai, M. (2000) 'Membrane emulsification a versatile tool for the synthesis of polymeric microspheres', Macromol. Symp., 151: 319-330.

Omi, S., Kanetaka, A., Shimamori, Y., Supsakulchai, A., Nagai, M. and Ma, G.H. (2001) 'Magnetite $\left(\mathrm{Fe}_{3} \mathrm{O}_{4}\right)$ microcapsules prepared using a glass membrane and solvent removal', $J$. Microencapsulation, 19: 749-765.

Pan, X., York, D., Preece, J.A. and Zhang, Z. (2012) 'Size and strength distributions of melamine-formaldehyde microcapsules prepared by membrane emulsification', Powder Technol., 227: 43-50. 
Pham, T.T., Jaafar-Maalej, C., Charcosset, C. and Fessi, H. (2012) 'Liposome and niosome preparation using a membrane contactor for scale-up’, Colloids Surf., B, 94: 15-21.

Park, S.H., Yamaguchi, T. and Nakao, S. (2001) 'Cut-off of dilute O/W emulsions through a microfiltration membrane’, J. Membr. Sci., 190: 167-178.

Piacentini, E., Giorno, L., Dragosavac, M.M., Vladisavljević, G.T. and Holdich, R.G. (2013) 'Microencapsulation of oil droplets using cold water fish gelatine/gum arabic complex coacervation by membrane emulsification', Food Res. Int., 53: 362-372.

Piacentini, E., Drioli, E. and Giorno, L. (2013b) 'Pulsed back-and-forward cross-flow batch membrane emulsification with high productivity to obtain highly uniform and concentrate emulsions', J. Membr. Sci., 453: 119-125.

Piacentini, E., Shanthana Lakshmi, D., Figoli, A., Drioli, E. and Giorno, L. (2013c) 'Polymeric microspheres preparation by membrane emulsification-phase separation induced process', J. Membr. Sci.: 448, 190-197.

Piacentini, E., Drioli, G. and Giorno, L. (2014) 'Membrane emulsification technology: Twenty-five years of inventions and research through patent survey', J. Membr. Sci., 468, 410-422.

Pradhan, R., Lee, D.W., Choi, H.G., Yong, C.S. and Kim, J.O. (2013) 'Fabrication of a uniformly sized fenofibrate microemulsion by membrane emulsification', $J$. Microencapsulation, 30: 42-48.

Qi, F., Wu, J., Hao, D., Yang, T., Ren, Y., Ma, G. and Su, Z. (2014) 'Comparative studies on the influences of primary emulsion preparation on properties of uniform-sized exenatideloaded PLGA microspheres', Pharm. Res., 31: 1566-1574.

Rahman, A., Dickinson, M.E., Farid, M.M. (2012) 'Microencapsulation of a PCM through membrane emulsification and nanocompression-based determination of microcapsule strength', Mater. Renew. Sustain. Energy, 1:4.

Ramakrishnan, S., Ferrando, M., Aceña-Muñoz, L., De Lamo-Castellví, S. and Güell, C. (2013) 'Fish oil microcapsules from o/w emulsions produced by premix membrane emulsification', Food Bioprocess Technol., 6: 3088-3101.

Rayner, M., Trägårdh, G., Trägårdh, C. and Dejmek, P. (2004) 'Using the Surface Evolver to model droplet formation processes in membrane emulsification', J. Colloid Interface Sci., 279: 175-185. 
Rayner, M., Trägårdh, G. and Trägårdh, C. (2005) 'The impact of mass transfer and interfacial expansion rate on droplet size in membrane emulsification processes', Colloids Surf., A, 266: 1-17.

Sabouni, R. and Gomaa, H.G. (2015) 'Preparation of Pickering emulsions stabilized by metal organic frameworks using oscillatory woven metal micro-screen', Soft Matter, 11: 4507-4516. Sakai, S., Hashimoto, I., Ogushi, Y. and Kawakami, K. (2007) 'Peroxidase-catalyzed cell encapsulation in subsieve-size capsules of alginate with phenol moieties in water-immiscible fluid dissolving $\mathrm{H}_{2} \mathrm{O}_{2}$ ', Bomacromolecules, 8: 2622-2626.

Santos, J., Vladisavljević, G.T., Holdich, R.G., Dragosavac, M,M. and Muñoz, J. (2015) 'Controlled production of eco-friendly emulsions using direct and premix membrane emulsification', Chem. Eng. Res. Des., 98: 59-69.

Sawalha, H., Fan, Y., Schroën, K. and Boom, R. (2008) 'Preparation of hollow polylactide microcapsules through premix membrane emulsification-Effects of nonsolvent properties', $J$. Membr. Sci., 325: 665-671.

Schadler, V. and Windhab, E.J. (2006) 'Continuous membrane emulsification by using a membrane system with controlled pore distance', Desalination, 189: 130-135.

Schork, F.J., Luo, Y., Smulders, W., Russum, J.P., Butté, A. and Fontenot, K. (2005) 'Miniemulsion polymerization', Adv. Polym. Sci., 175: 129-255.

Schröder, V., Behrend, O. and Schubert H. (1998) 'Effect of dynamic interfacial tension on the emulsification process using microporous, ceramic membrane', J. Colloid Interface Sci., 202: 334-340.

Schroën, K., Bliznyuk, O., Muijlwijk, K., Sahin, S. and Berton-Carabin, C.C. (2015) 'Microfluidic emulsification devices: from micrometer insights to large-scale food emulsion production’, Curr. Opin. Food Sci., 3: 33-40.

Seto, H., Ohto, K. and Kawakita, H. (2011) 'Reversible extension and shrinkage of solventresponsive dextran chains produced by enzymatic reaction', J. Membr. Sci., 370: 76-81.

Segura, R., Cierpka, C., Rossi, M., Joseph, S., Bunjes, H. and Kähler, C. (2013) 'Nonencapsulated thermo-liquid crystals for digital particle tracking thermography/velocimetry in microfluidics’, Microfluid. Nanofluid., 14: 445-456.

Sherrington, D.C. (1998) 'Preparation, structure and morphology of polymer supports', Chem. Commun., 2275-2286. 
Shimoda, M., Miyamae, H., Nishiyama, K., Yuasa, T., Noma, S. and Igura, N. (2011) 'Swirlflow membrane emulsification for high throughput of dispersed phase flux through Shirasu porous glass (SPG) membrane', J. Chem. Eng. Jpn, 44: 1-6.

Si, T., Wang, Y., Wei, W., Lv, P., Ma, G. and Su, Z. (2011) 'Effect of acrylic acid weight percentage on the pore size in poly(N-Isopropyl acrylamide-co-acrylic acid) microspheres', React. Funct. Polym., 71: 728-735.

Silva, P.S., Stillwell, M., Williams, B., Dragosavac, M., Vladisavljević, G.T., Bandulasena, H. and Holdich, R.G. (2015) 'Azimuthally oscillating membrane emulsification for controlled droplet production', AIChE J., doi: 10.1002/aic.14894.

Slomkowski, S., Alemán, J.V., Gilbert, R.G., Hess, M., Horie, K., Jones, R.G., Przemyslaw, K. Meisel, I., Mormann, W., Penczek, S. and Stepto, R.F.T. (2011) 'Terminology of polymers and polymerization processes in dispersed systems (IUPAC Recommendations 2011)', Pure Appl. Chem., 83: 2229-2259.

Spyropoulos, F., Lloyd, D., Hancocks, R.D. and Pawlik, A.K. (2014) 'Advances in membrane emulsification. Part B: Recent developments in modelling and scale-up approaches', J. Sci. Food Agric., 94: 628-638.

Srivastava, S., Schaefer, J.L., Yang , Z., Tu, Z. and Archer, L.A. (2014) '25th anniversary article: polymer-particle composites: phase stability and applications in electrochemical energy storage', Adv. Mater., 26: 201-234.

Strathmann, H. and Kock, K. (1977) 'The formation mechanism of phase inversion membranes', Desalination, 21, 241-255.

Sugiura, S., Nakajima, M., Kumazawa, N., Iwamoto, S. and Seki, M. (2002) 'Characterization of spontaneous transformation-based droplet formation during microchannel emulsification', J. Phys. Chem. B, 106: 9405-9409.

Sugiura, S., Oda, T., Izumida, Y., Aoyagi, Y., Satake, M., Ochiali, A., Ohkohchi, N. and Nakajima, M. (2005) 'Size control of calcium alginate beads containing living cells using micro-nozzle array’, Biomaterials, 26: 3327-3331.

Sun, H., Li, X., Ma, G. and Su, Z. (2005) 'Polystyrene-type uniform porous microsphere enables high resolution and low-pressure chromatography of natural products - a case study with icariin purification', Chromatographia, 61: 9-15.

Sun, G., Qi, F., Wu, J., Ma, G. and Ngai, T. (2014) 'Preparation of uniform particle-stabilized emulsions using SPG membrane emulsification’, Langmuir, 30: 7052-7056.

Supsakulchai, A., Ma, G.H., Nagai, M. and Omi, S. (2002) 'Microencapsulation of fine 
titanium dioxide powders from (S/O)/W emulsion with subsequent solvent evaporation', ACS Symp. Ser., 801: 260-275.

Supsakulchai, A., Ma, G.H., Nagai, M. and Omi, S. (2002b) 'Uniform titanium dioxide $\left(\mathrm{TiO}_{2}\right)$ microcapsules prepared by glass membrane emulsification with subsequent solvent evaporation', J. Microencapsulation, 19: 425-449.

Supsakulchai, A., Ma, G.H., Nagai, M. and Omi, S. (2003) 'Preparation of uniform titanium dioxide $\left(\mathrm{TiO}_{2}\right)$ polystyrene-based composite particles using the glass membrane emulsification process with a subsequent suspension polymerization', J. Microencapsulation, 20, 1-18.

Surh, J., Vladisavljević, G.T., Mun, S. and McClements, D.J. (2007) 'Preparation and characterization of water/oil and water/oil/water emulsions containing biopolymergelled water droplets’, J. Agric. Food Chem., 55: 175-184.

Surh, J., Jeong, Y.G. and Vladisavljević, G.T. (2008) 'On the preparation of lecithinstabilized oil-in-water emulsions by multi-stage premix membrane emulsification', J. Food Eng., 89: 164-170.

Suzuki, K., Shuto, I. and Hagura, Y. (1996) 'Characteristics of the membrane emulsification method combined with preliminary emulsification for preparing corn oil-in-water emulsions', Food Sci. Technol. Int. Tokyo, 2: 43-47.

Suzuki, K., Kayakawa, K. and Hagura, Y. (1999) 'Preparation of high concentration O/W and W/O emulsions by the membrane phase inversion emulsification using PTFE membranes', Food Sci. Technol. Int. Tokyo, 5: 234-238.

Takeda, M., Tanabe, E., Iwaki, T., Yabuki, A. and Okuyama, K. (2009) 'Importance of dispersibility of $\mathrm{TiO}_{2}$ in preparation of $\mathrm{TiO}_{2}$-dispersed microspheres by Shirasu porous glass (SPG) membrane emulsification’, Adv. Powder Technol., 20: 361-365.

Tanaka, T., Okayama, M., Kitayama, Y., Kagawa, Y. and Okubo, M. (2010) 'Preparation of "mushroom-like” janus particles by site-selective surface-initiated atom transfer radical polymerization in aqueous dispersed systems, Langmuir, 26: 7843-7847.

Torigoe, K., Shimizu, M., Yamamoto, K., Mizozoe, M., Takahashi, H., Suzuki, T. and Murase, M. (2011) 'Method and apparatus for manufacturing low melting point metal fine particles’, US patent 7,976,608, 12 July 2011.

Urban, J., Svec, F. and Fréchet, J.M. (2010) 'Hypercrosslinking: new approach to porous polymer monolithic capillary columns with large surface area for the highly efficient separation of small molecules’, J. Chromatogr. A., 1217: 8212-8221. 
van Rijn, C., van der Wekken, M., Nijdam, W. and Elwenspoek, M. (1997) 'Deflection and maximum load of microfiltration membrane sieves_made with silicon micromachining', $J$. Microelectromech. Syst., 6: 48-54.

Vasapollo, G., Sole, R.D., Mergola, L., Lazzoi, M.R., Scardino, A., Scorrano, S. and Mele, G. (2011) 'Molecularly imprinted polymers: present and future prospective', Int. J. Mol. Sci., 12: 5908-5945.

Veldhuis, G., Gironés, M. and Bingham, D. (2009) 'Monodisperse microspheres for parenteral drug delivery’, Drug Deliv. Technol., 9: 23-31.

Viebke, V., Piculell, L. and Nilsson, S. (1994) 'On the mechanism of gelation of helixforming biopolymers’, Biomacromolecules, 27: 4160-4166.

Vladisavljević, G.T. and Schubert, H. (2002) 'Preparation and analysis of oil-in-water emulsions with a narrow droplet size distribution using Shirasu-porous-glass (SPG) membranes', Desalination, 144: 167-172.

Vladisavljević, G.T. and Schubert, H. (2003a) 'Preparation of emulsions with a narrow particle size distribution using microporous $\alpha$-alumina membranes', J. Dispersion Sci. Technol., 24: 811-819.

Vladisavljević, G.T. and Schubert, H. (2003b) 'Influence of process parameters on droplet size distribution in SPG membrane emulsification and stability of prepared emulsion droplets', J. Membr. Sci., 225: 15-23.

Vladisavljević, G.T., Lambrich, U., Nakajima M. and Schubert H. (2004) 'Production of O/W emulsions using SPG membranes, ceramic $\alpha-\mathrm{Al}_{2} \mathrm{O}_{3}$ membranes, microfluidizer and a microchannel plate: a comparative study’, Colloids Surf., A, 232: 199-207.

Vladisavljević, G.T., Shimizu, M. and Nakashima, T. (2004b) 'Preparation of monodisperse multiple emulsions at high production rates by multi-stage premix membrane emulsification', J. Membr. Sci., 244: 97-106.

Vladisavljević, G.T., Shimizu, M. and Nakashima, T. (2005) 'Permeability of hydrophilic and hydrophobic Shirasu-porous-glass (SPG) membranes to pure liquids and its microstructure', $J$. Membr. Sci., 250: 69-77.

Vladisavljević, G.T. and Williams, R.A. (2005) 'Recent developments in manufacturing emulsions and particulate products using membranes', Adv. Colloid Interface Sci., 113: 1-20. Vladisavljević, G.T. and Williams, R.A. (2006) 'Manufacture of large uniform droplets using rotating membrane emulsification’, J. Colloid Interface Sci., 299: 396-402.

Vladisavljević, G.T., Shimizu, M. and Nakashima, T. (2006) 'Production of multiple 
emulsions for drug delivery systems by repeated SPG membrane homogenization: Influence of mean pore size, interfacial tension and continuous phase viscosity', J. Membr. Sci., 284: 373-383.

Vladisavljević, G.T., Surh, J. and McClements, D.J. (2006b) 'Effect of emulsifier type on droplet disruption in repeated Shirasu porous glass membrane homogenization', Langmuir, 22: $4526-4533$.

Vladisavljević, G.T., Kobayashi, I., Nakajima, M., Williams, R.A., Shimizu, M. and Nakashima, T. (2007) 'Shirasu Porous Glass membrane: Characterisation of microstructure by high resolution $\mathrm{x}$-ray microtomography and visualisation of droplet formation in real time’, J. Membr. Sci., 302: 243-253.

Vladisavljević, G.T. and Williams, R.A. (2008) 'Recent developments in manufacturing particulate products from double-emulsion templates using membrane and microfluidic devices', in Aserin, A. (ed.), Multiple Emulsions: Technology and Applications, Hoboken: John Wiley \& Sons, Inc.

Vladisavljević, G.T., Kobayashi, I. and Nakajima, M. (2008) 'Generation of highly uniform droplets using asymmetric microchannels fabricated on a single crystal silicon plate: Effect of emulsifier and oil types', Powder Technol., 183: 37-45.

Vladisavljević, G.T. and Williams, R.A. (2010) 'Recent developments in manufacturing nanoparticles from emulsion droplets', in Starov, V. (ed.), Nanoscience: Colloidal and Interfacial Aspects, Boca Raton: CRC Press, pp. 437-491.

Vladisavljević, G.T. and McClements, D.J. (2010) 'Modification of interfacial characteristics of monodisperse droplets produced using membrane emulsification by surfactant displacement and/or polyelectrolyte electrostatic deposition', Colloids Surf., A, 364: 123-131. Vladisavljević, G.T., Kobayashi, I. and Nakajima, M. (2011) 'Effect of dispersed phase viscosity on maximum droplet generation frequency in microchannel emulsification using asymmetric straight-through channels’, Microfluid. Nanofluid., 10: 1199-1209.

Vladisavljević, G.T., Kobayashi, I. and Nakajima, M. (2012) 'Production of uniform droplets using membrane, microchannel and microfluidic emulsification devices', Microfluid. Nanofluid., 13: 151-178.

Vladisavljević, G.T., Duncanson, W.J., Shum, H.C. and Weitz, D.A. (2012b) 'Emulsion templating of poly(lactic acid) particles: droplet formation behaviour', Langmuir, 28: $12948-12954$. 
Vladisavljević, G.T., Wang, B., Dragosavac, M.M. and Holdich, R.G. (2014) 'Production of food-grade multiple emulsions with high encapsulation yield using oscillating membrane emulsification', Colloid. Surf. A, 458: 78-84.

Wagdare, N.A., Marcelis, A.T.M., Ho, O.B., Boom, R.M. and van Rijn, C.J.M. (2010) 'High throughput vegetable oil-in-water emulsification with a high porosity micro-engineered membrane’, J. Membr. Sci., 347: 1-7.

Wagdare, N.A., Marcelis, A.T.M., Boom, R.M. and van Rijn, C.J.M. (2011) 'Porous microcapsule formation with microsieve emulsification', J. Colloid Interface Sci., 355: 453-457.

Wang, L.Y., Ma, G.H. and Su, Z.G. (2005) 'Preparation of uniform sized chitosan microspheres by membrane emulsification technique and application as a carrier of protein drug', J. Controlled Release, 106: 62-75.

Wang, G., Dou, H. and Sun, K. (2012) 'Facile synthesis of hollow polymeric microparticles possessing various morphologies via seeded polymerization', Colloid Polym. Sci., 290: 18671877.

Wang, G., Leng, Y., Dou, H., Wang, L., Li, W., Wang, X., Sun, K., Shen, L., Yuan, X., Li, J., Sun, K., Han, J., Xiao, H. and Li, Y. (2013) 'Highly efficient preparation of multiscaled quantum dot barcodes for multiplexed hepatitis B detection', ASC Nano, 7: 471-481.

Wu, J., Fan, Q., Xia, Y. and Ma, G. (2015) 'Uniform-sized particles in biomedical field prepared by membrane emulsification technique’, Chem. Eng. Sci., 125: 85-97.

Thompson, K.L., Armes, S.P. and York, D.W. (2011) 'Preparation of Pickering emulsions and colloidosomes with relatively narrow size distributions by stirred cell membrane emulsification', Langmuir, 27: 2357-2363.

Wang, Y., Qin, J., Yi, W., Li, C. and Ma, G. (2013b) 'Preparation strategies of thermosensitive P(NIPAM-co-AA) microspheres with narrow size distribution', Powder Technol., 236: 107-113.

Wang, L., Cai, M., Liu, Y., Yang, T., Zeng, Y., Zhang, Y., Li, Q., Zhu, B. and Ma, G. (2015) 'Polymer hydrophobicity regulates paclitaxel distribution in microspheres, release profile and cytotoxicity in vitro’, Powder Technol., 275: 77-84.

Wang, L., Yang, T. and Ma, G. (2015b) 'Particle design of membrane emulsification for protein drug and vaccine delivery’, Curr. Pharm. Des., 21: 2563-2598. 
Wei, Q., Wei, W., Tian, R., Wang, L.Y., Su, Z.G. and Ma, G.H. (2008) 'Preparation of uniform-sized PELA microspheres with high encapsulation efficiency of antigen by premix membrane emulsification’, J. Colloid Interface Sci., 323: 267-273.

Wei, W., Ma, G.H., Wang, L.Y., Wu, J. and Su, Z.G. (2010) 'Hollow quaternized chitosan microspheres increase the therapeutic effect of orally administered insulin', Acta Biomater., 6: 205-209.

Wei, Y., Wang, Y., Wang, L., Hao, D. and Ma, G.H. (2011) 'Fabrication strategy for amphiphilic microcapsules with narrow size distribution by premix membrane emulsification', Colloids Surf., B, 87: 399-408.

Wei, Y., Wang, Y.X., Wang, W., Ho, S.V., Wei, W. and Ma, G.H. (2011b) 'mPEG-PLA microspheres with narrow size distribution increase the controlled release effect of recombinant human growth hormone’, J. Mater. Chem., 21: 12691-12699.

Wei W., Lv, P.P., Chen, X.M., Yue, Z.G., Fu, Q., Liu, S.Y., Yue, H. and Ma, G.H. (2013) 'Codelivery of mTERT siRNA and paclitaxel by chitosan-based nanoparticles promoted synergistic tumor suppression’, Biomaterials, 34: 3912-3923.

Wolska, J. and Bryjak, M. (2014) 'Removal of bisphenol A from aqueous solution by molecularly imprinted polymers’, Sep. Sci. Technol., 49: 1643-1653,

Wu, J., Wei, W., Wang, L.Y., Su, Z.G. and Ma, G.H. (2008) 'Preparation of uniform-sized $\mathrm{pH}$-sensitive quaternized chitosan microsphere by combining membrane emulsification technique and thermal-gelation method', Colloids Surf., B, 63: 164-175.

Wu, D.Y., Meure, S. and Solomon, D. (2008b) 'Self-healing polymeric materials: A review of recent developments', Prog. Polym. Sci., 33: 479-522.

Xiao, Z., Liu, W., Zhu, G., Zhou, R. and Niu, Y. (2014) 'A review of the preparation and application of flavour and essential oils microcapsules based on complex coacervation technology', J. Sci. Food Agric., 94: 1482-1494.

Xu, J.H., Luo, G.S., Chen, G.G. and Tan, B. (2005) 'Mass transfer performance and twophase flow characteristic in membrane dispersion mini-extractor', J. Membr. Sci., 249: 75-81. Yamamoto, T., Ohmori, T. and Kim, Y.H. (2008) 'Preparation and characterization of monodisperse carbon cryogel microspheres', Microporous Mesoporous Mater., 112: 211218.

Yamamoto, T., Ohmori, T. and Kim, Y.H. (2010) 'Synthesis of monodisperse carbon cryogel microspheres using membrane emulsification of a phenol-formaldehyde solution', Carbon, 48: $912-928$. 
Yamashita, N., Konishi, N., Tanaka, T. and Okubo, M. (2012) 'Preparation of hemispherical polymer particles by cleavage of a Janus poly(methyl methacrylate) /polystyrene composite particle’, Langmuir, 28: 12886-12892.

Yang, J., Hao, D.X., Bi, C.X., Su, Z.G., Wang, L.Y. and Ma, G.H. (2010) 'Rapid synthesis of uniform magnetic microspheres by combing premix membrane emulsification and in situ formation techniques', Ind. Eng. Chem. Res., 49: 6047-6053.

Yasuda, M., Goda, T., Ogino, H., Glomm, W.R. and Takayanagi, H. (2010) 'Preparation of uniform monomer droplets using packed column and continuous polymerization in tube reactor', J. Colloid Interface Sci., 349: 392-410.

You, J.O., Park, S.B., Park, H.Y., Haam, S., Chung, C.H. and Kim, W.S. (2001) 'Preparation of regular sized Ca-alginate microspheres using membrane emulsification method', $J$. Microencapsulation, 18: 521-532.

Yuan, Q., Cayre, O.J., Manga, M., Williams, R.A. and Biggs, S. (2010) 'Preparation of particle-stabilized emulsions using membrane emulsification', Soft Matter, 6: 1580-1588.

Yue, Z.G., Wei, W., Lv, P.P., Yue, H., Wang, L.Y., Su, Z.G. and Ma, G.H. (2011) 'Surface charge affects cellular uptake and intracellular trafficking of chitosan-based nanoparticles', Biomacromolecules, 12: 2440-2446.

Yue, H., Wei, W., Fan, B., Yue, Z., Wang, L., Ma, G. and Su, Z. (2012) 'The orchestration of cellular and humoral responses is facilitated by divergent intracellular antigen trafficking in nanoparticle-based therapeutic vaccine’, Pharmacol. Res., 65: 189-197.

Yuyama, H., Hashimoto, T., Ma, G.H., Nagai, M. and Omi, S. (2000) 'Mechanism of suspension polymerization of uniform monomer droplets prepared by glass membrane (Shirasu Porous Glass) emulsification technique’, J. Appl. Polym. Sci., 78: 1025-1043.

Yuyama, H., Yamamoto, K., Shirafuji, K., Nagai, M. and Ma, G.H. (2000b) 'Preparation of polyurethaneurea (PUU) uniform spheres by SPG membrane emulsification technique', $J$. Appl. Polym. Sci., 77: 2237-2245.

Zeng, W., Gomaa, H.G., Liu, J. and Zhu, J. (2013) 'Intensification of production of O/W emulsions using oscillatory woven metal micro-screen (WMMS)', Chem. Eng. Process., 73: 111-118.

Zhang, Y., Wei, W., Lv, P., Wang, L. and Ma, G. (2011) 'Preparation and evaluation of alginate-chitosan microspheres for oral delivery of insulin', Eur. J. Pharm. Biopharm., 77: 11-19.

Zhang, W., Wang, L., Liu, Y., Chen, X., Li, J., Yang, T., An, W., Ma, X., Pan, R. and Ma, G. 
(2014) 'Comparison of PLA microparticles and alum as adjuvants for H5N1 influenza split vaccine: adjuvanticity evaluation and preliminary action mode analysis', Pharm. Res., 31: 1015-1031.

Zhang, W., Wang, L., Liu, Y., Chen, X., Li, Q., Jia, J., Yang, T., Qiu, S. and Ma, G. (2014b) 'Immune responses to vaccines involving a combined antigene-nanoparticle mixture and nanoparticle-encapsulated antigen formulation’, Biomaterials, 35: 6086-6097.

Zhou, Q.Z., Wang, L.Y., Ma, G.H. and Su, Z.G. (2007) 'Preparation of uniform-sized agarose beads by microporous membrane emulsification technique’, J. Colloid Interface Sci., 311: $118-127$.

Zhou, Q.Z., Wang, L.Y., Ma, G.H. and Su, Z.G. (2008) 'Multi-stage premix membrane emulsification for preparation of agarose microbeads with uniform size', J. Membr. Sci., 322: 98-104.

Zhou, Q.Z., Ma, G.H. and Su, Z.G. (2009) 'Effect of membrane parameters on the size and uniformity in preparing agarose beads by premix membrane emulsification', J. Membr. Sci., 326: 694-700.

Zhou, Q., Tang, S., Zhang, M. and Li, A. (2011) 'Preparation of uniform hypercrosslinked microspheres with large specific surface area', Adv. Mater. Res., 239-242: 1842-1845.

Zhou, Q., Zhang, M.C., Shuang, C.D., Li, Z.Q. and Li, A.M. (2012) 'Preparation of a novel magnetic powder resin for the rapid removal of tetracycline in the aquatic environment', Chin. Chem. Lett., 23: 745-748.

Zhang, M., Zhou, Q., Li, A., Shuang, C., Wang, W. and Wang, M. (2013) 'A magnetic sorbent for the efficient and rapid extraction of organic micropollutants from large-volume environmental water samples', J. Chromatogr. A., 1316: 44-52.

Zhao, X., Wu, J., Gong, F.L., Cui, J.M., Janson, J.C., Ma, G.H. and Su, Z.G. (2014) 'Preparation of uniform and large sized agarose microspheres by an improved membrane emulsification technique', Powder Technol., 253: 444-452.

van der Zwan, E.A., Schroën, C.G.P.H. and Boom, R.M. (2008) 'Premix membrane emulsification by using a packed layer of glass beads', AIChE J., 54: 2190-2197. 


\section{Figure captions}

Figure 1. Schematic diagram of two principal membrane emulsification processes.

Figure 2. Spinodal decomposition of glass induced by cooling mother glass from an initial temperature $T_{1}$ to temperature $T_{2}$ lying in the spinodal region (within the spinodal line). To prevent phase separation via nucleation, a transition from the stable to the spinodal region of the phase diagram must proceed quickly or through the upper critical solution temperature (UCST).

Figure 3. Chemical modification of SPG surface by treatment with organosilane compounds: (a) Hydrophobic treatment with monochlorosilanes (Kai et al., 2006); (b) Introduction of amino groups by amino trialkoxysilanes to render the surface positively charged.

Figure 4. A diagram of a typical experimental set-up for cross flow DME using tubular SPG membrane. During start-up, valve $\mathbf{1}$ must be open to remove any trapped air from the module (Nakashima et al., 1994).

Figure 5. Commercial membrane emulsification micro kits available by SPG Techology Co., Ltd (Sadowara, Japan): (a) External-pressure type for DME; (b) External-pressure type for PME; (c) Internal-pressure type for DME. The effective length of membrane tube is 10-15 $\mathrm{mm}$.

Figure 6. Contact angles through water phase and phase pressures encountered in membrane emulsification: (a) Production of $\mathrm{O} / \mathrm{W}$ emulsion $\left(\theta<90^{\circ}, P_{o}>P_{w}\right)$; (b) Production of W/O emulsion $\left(\theta>90^{\circ}, P_{o}<P_{w}\right)$. The contact angle $\theta$ is the angle measured through the water phase, where a water/oil interface meets a membrane surface $\left(\gamma_{m w}=\right.$ interfacial tension between membrane wall and water phase, $\gamma_{m o}=$ interfacial tension between membrane wall and oil phase, $\gamma_{w o}=$ interfacial tension between water and oil phase).

Figure 7. Mean droplet size, $d_{d}$ in DME (dashed lines) and PME (solid lines) versus mean pore size, $d_{p}$ and transmembrane flux, $J$ : (1) $d_{d}$ vs. $J$ in shear-controlled DME; (2) $d_{d}$ vs. 
$J$ in interfacial-tension driven DME; (3) $d_{d}$ vs. $d_{p}$ in interfacial-tension driven DME under dripping regime; (4) $d_{d}$ vs. $J$ in PME, 5) $d_{d}$ vs. $d_{p}$ in PME.

Figure 8. The main strategies used to crosslink droplets produced by ME in order to form solid or hollow gel microbeads.

Figure 9. Production of W/O/W emulsions containing biopolymer-gelled water droplets by high-pressure homogenisation, thermal gelation within the inner aqueous phase and PME (Surh et al., 2007).

Figure 10. Production of solid lipid carrier by integration of PME at $T>T_{m}$ and crystalisation of oil phase in the obtained $\mathrm{O} / \mathrm{W}$ emulsion at $T<T_{m}$.

Figure 11. Production of water-in-solid lipid (W/S) carrier by integration of two-stage DME at $T>T_{m}$ and crystalisation of oil phase in the obtained W/O/W emulsion at $T<T_{m}$.

Figure 12. Production of solid-in-solid lipid (S/S) carrier by PME at $T>T_{m}$ and crystalisation of oil phase in the obtained $\mathrm{S} / \mathrm{O} / \mathrm{W}$ emulsion at $T<T_{m}$.

Figure 13. Production of particles by membrane emulsification-solvent removal from $\mathrm{O} / \mathrm{W}$ emulsion.

Figure 14. Production of particles by membrane emulsification-solvent evaporation from $\mathrm{W}_{1} / \mathrm{O} / \mathrm{W}_{2}$ or $\mathrm{S} / \mathrm{O} / \mathrm{W}$ emulsion.

Figure 15. Preparation of porous polymer particles by solvent displacement induced phase separation (Pacentini et al., 2013c).

Figure 16. Preparation of permenantly porous polymer particles by membrane emulsification and subsequent processing: (a) Phase separation using a liquid solvent (porogen); (b) Postpolymerisation cross-linking (Zhou et al., 2011). 
Figure 17. Preparation of molecularly imprinted polymer particles by membrane emulsification (Kou et al., 2012).

Figure 18. Preparation of liquid-core-polymer-shell particles by membrane emulsification suspension polymerisation.

Figure 19. Preparation of liquid-core-polymer-shell particles by membrane emulsification followed by emulsification on the surface of the droplets: (a) interfacial polycondensation (IP) (Chu et al., 2002) and (b) in-situ polymerisation (ISP) (Pan et al., 2012).

Figure 20. Preparation of porous silica nanoshells loaded with magnetite nanoparticles and hydrophobic drug by membrane emulsification, miniemulsion polymerisation and sol-gel processing (Kong et al., 2013).

Figure 21. Preparation of carbon cryogel particles by sol-gel polycondensation of resorcinol with formaldehyde, combined with DME, freeze drying and pyrolysis (Yamamoto et al., 2010).

Figure 22. Preparation of complex coacervates by membrane emulsification (Piacentini et al. 2013).

Figure 23. Preparation of multilayer oil-in-water (M-O/W) emulsions by membrane emulsification: (a) Citrem-chitosan-alginate three-layer emulsion prepared by PME and LbL electrostatic deposition (Gudipati et al., 2010); (b) Tween 20-SDS-chitosan two-layer emulsion with cationic droplets prepared by PME, surfactant displacement and LbL electrostatic deposition (Vladisavljević and McClements, 2010); (c) BLG-alginate two-layer emulsion with anionic droplets prepared by PME and LbL electrostatic deposition with stepwise change in $\mathrm{pH}$ after mixing BLG-stabilized emulsion with alginate ( $\mathrm{Li}$ and McClements, 2014).

Figure 24. Preparation of colloidosomes by membrane emulsification and subsequent processing: (a) Covalent cross-linking (Sun et al., 2014); (b) Internal polymer deposition (Nan et al., 2014b). 
(a) Direct membrane emulsification (DME)

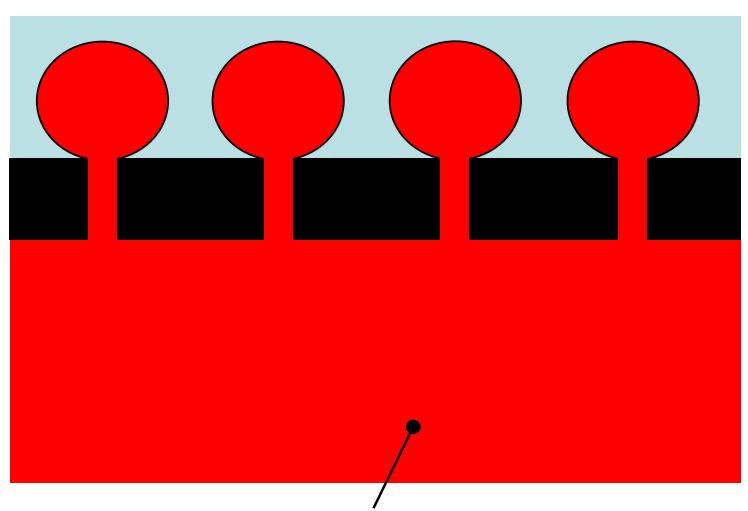

Pure dispersed phase (b) Premix membrane emulsification (PME)

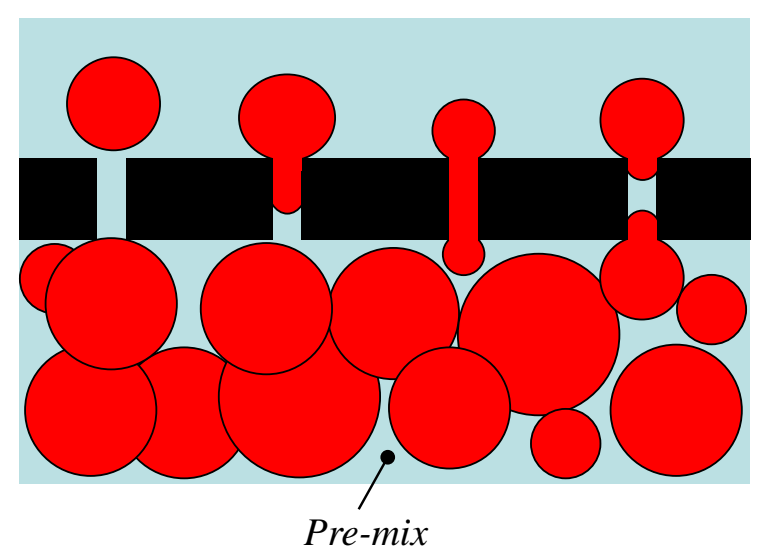

Figure 1 


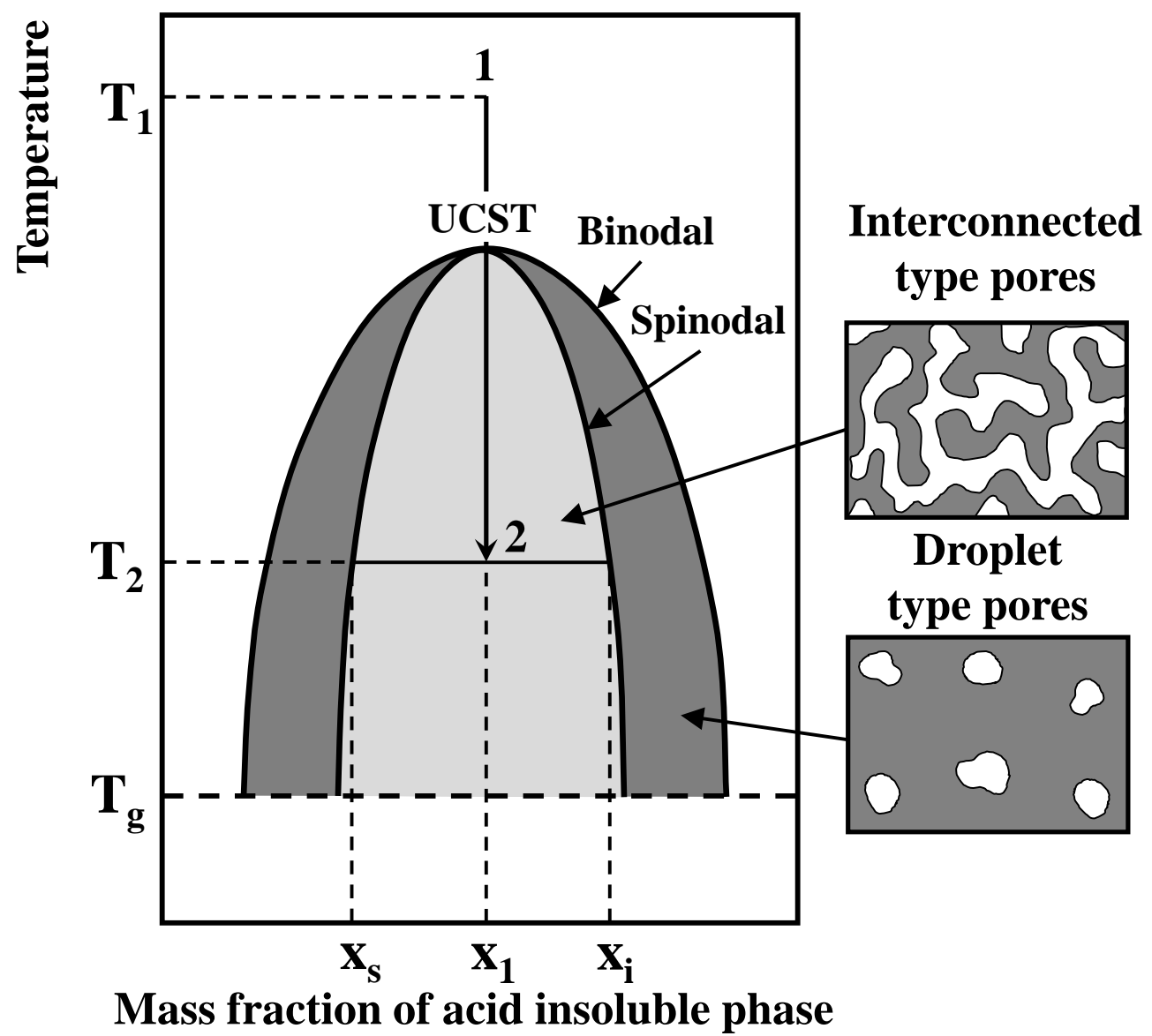

Figure 2 
(a) Hydrophobic treatment with monochlorosilanes (TMS and ODS)

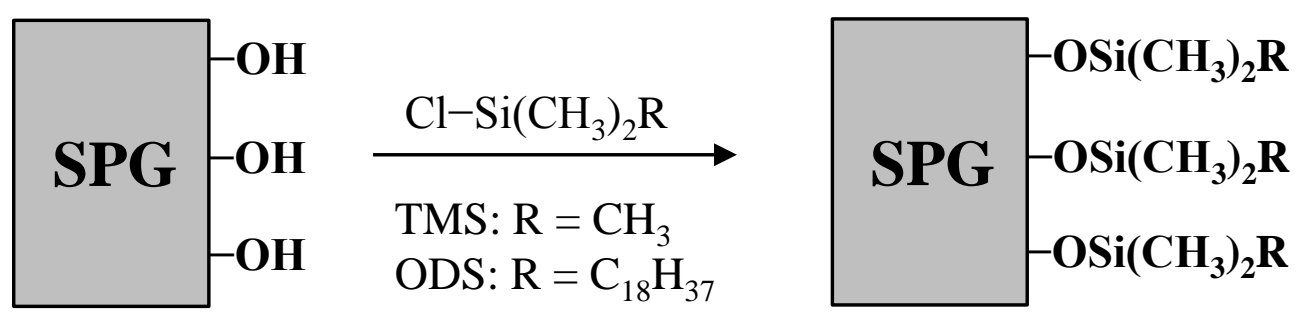

(b) Introduction of positive charge with amino trialkoxysilanes

(APTMS and APTES)

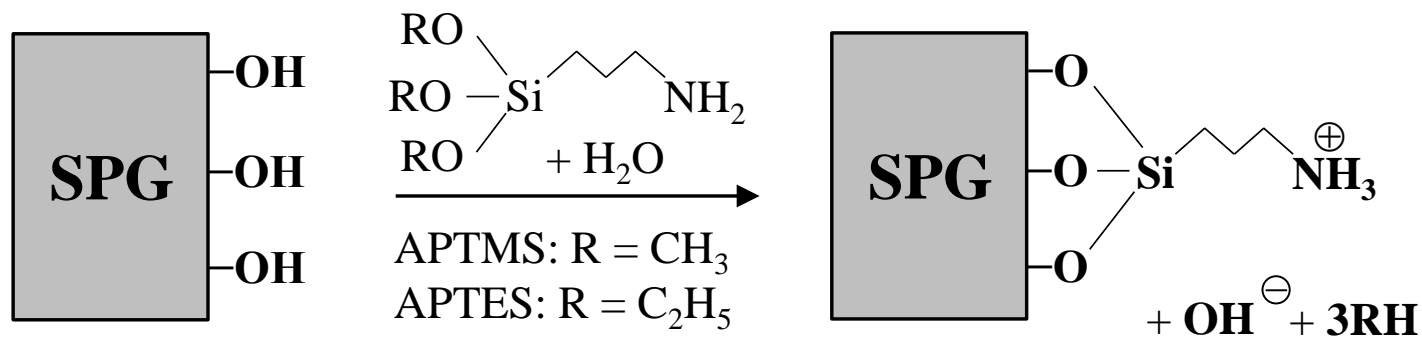

Figure 3 


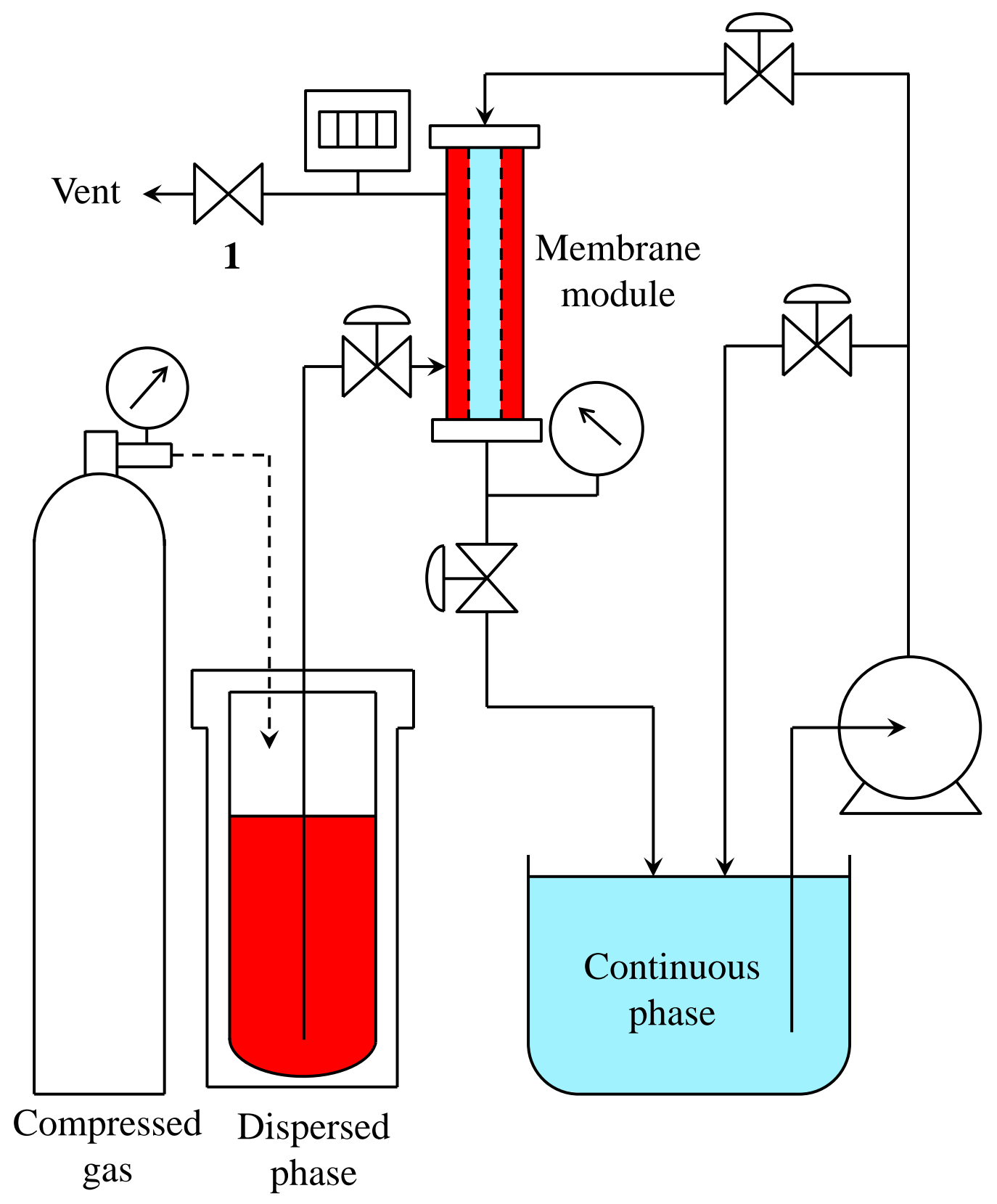

Figure 4 

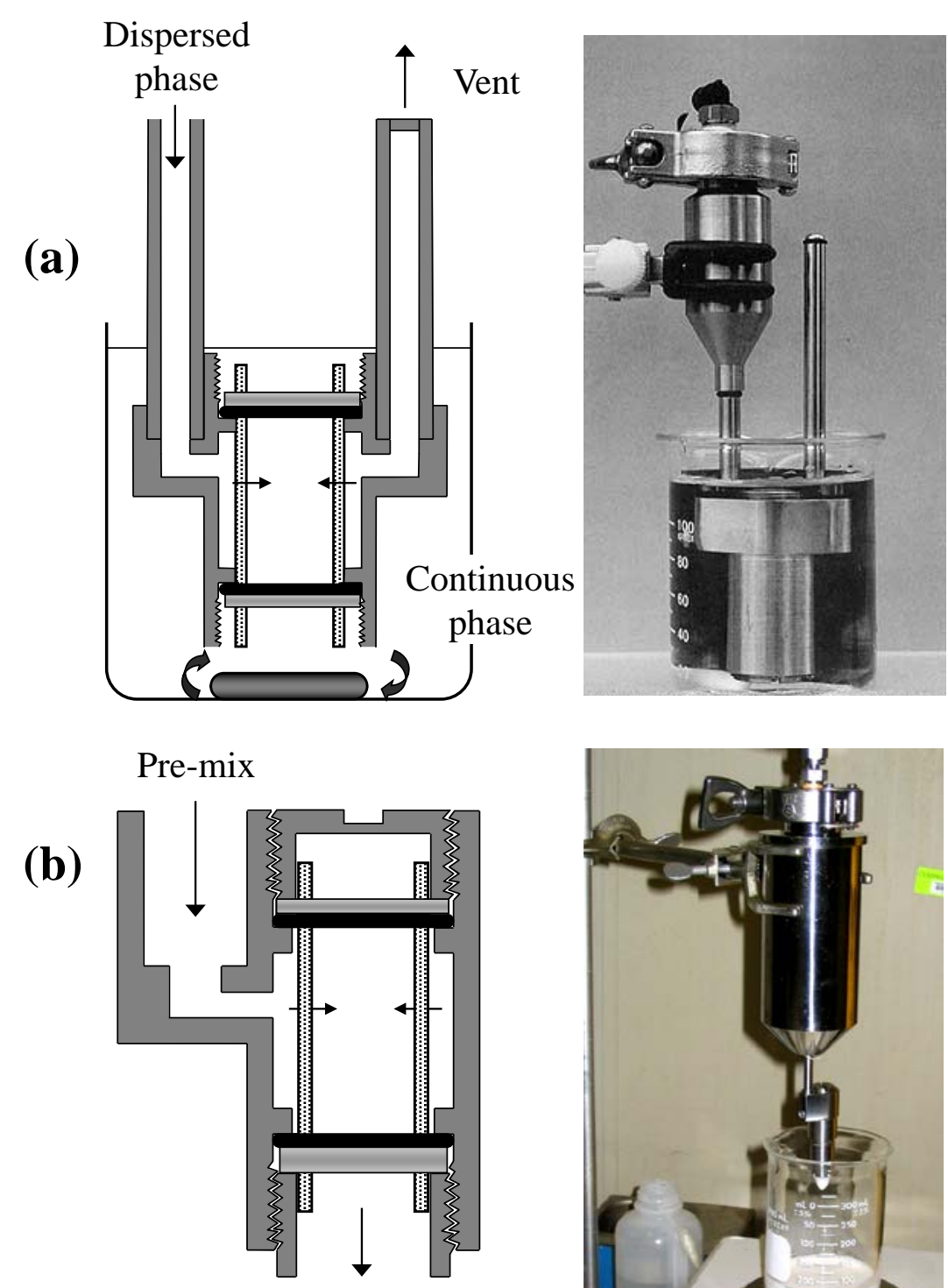

Emulsion
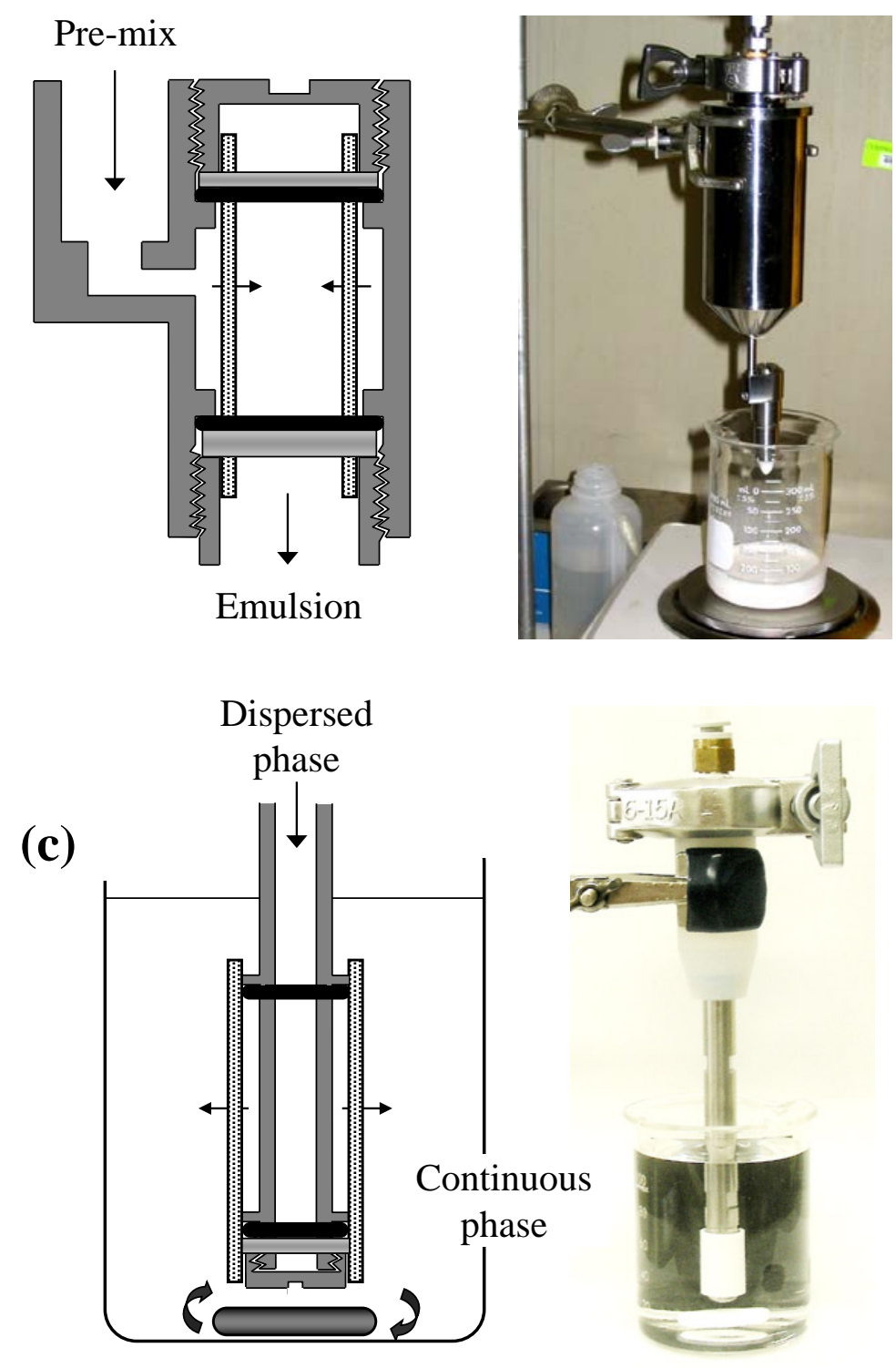

Figure 5 
(a) Hydrophilic membrane $\left(\theta<90^{\circ}\right)$

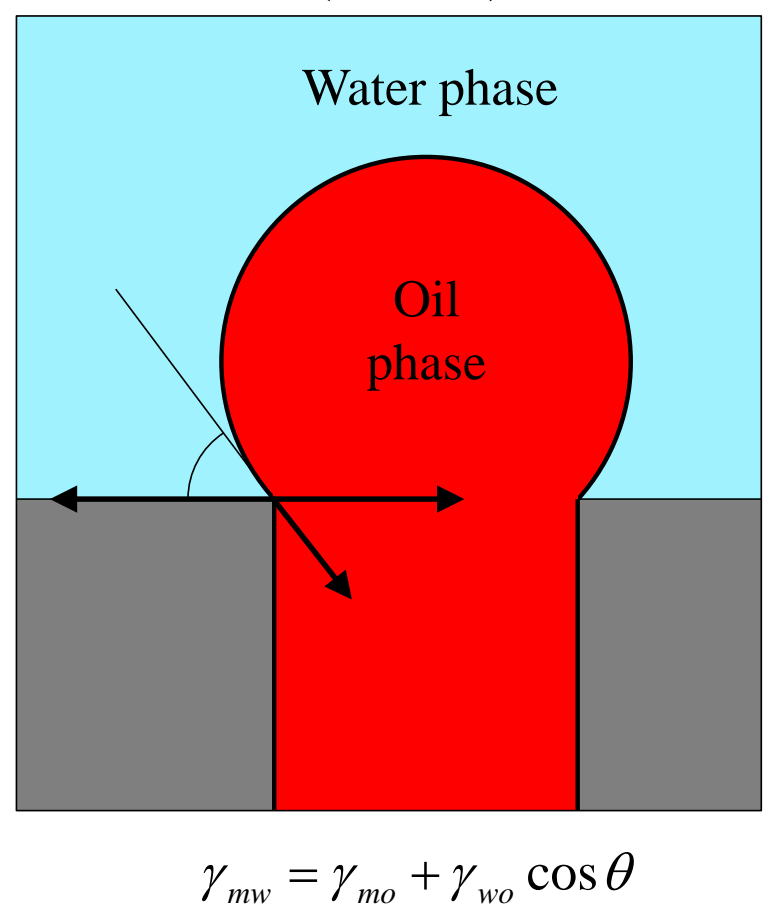

(b) Hydrophobic membrane $\left(\theta>90^{\circ}\right)$

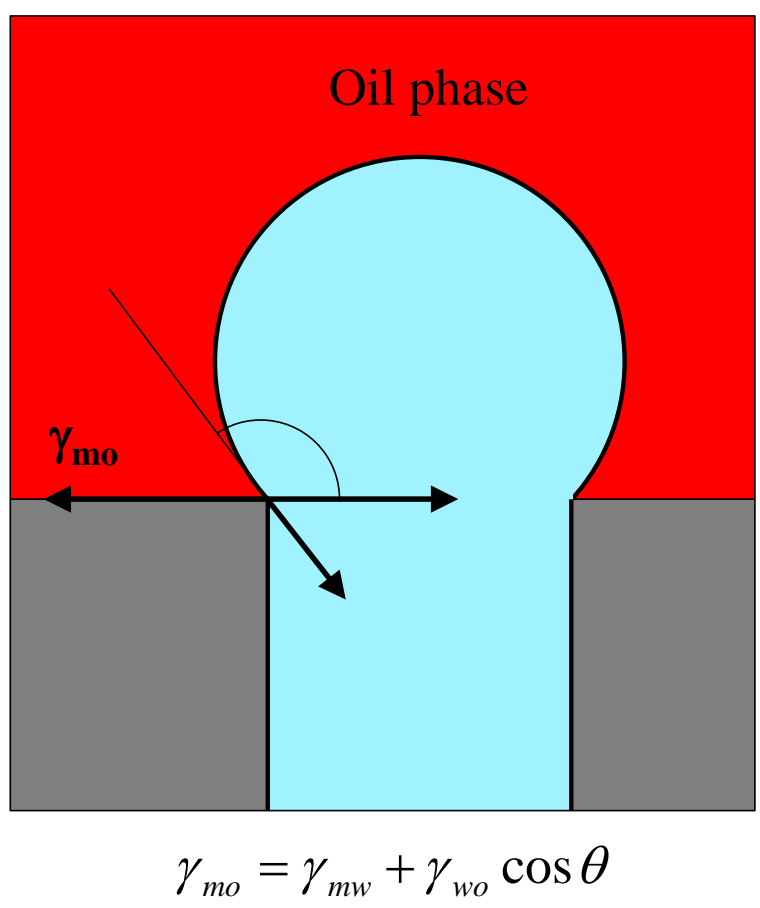

Figure 6 


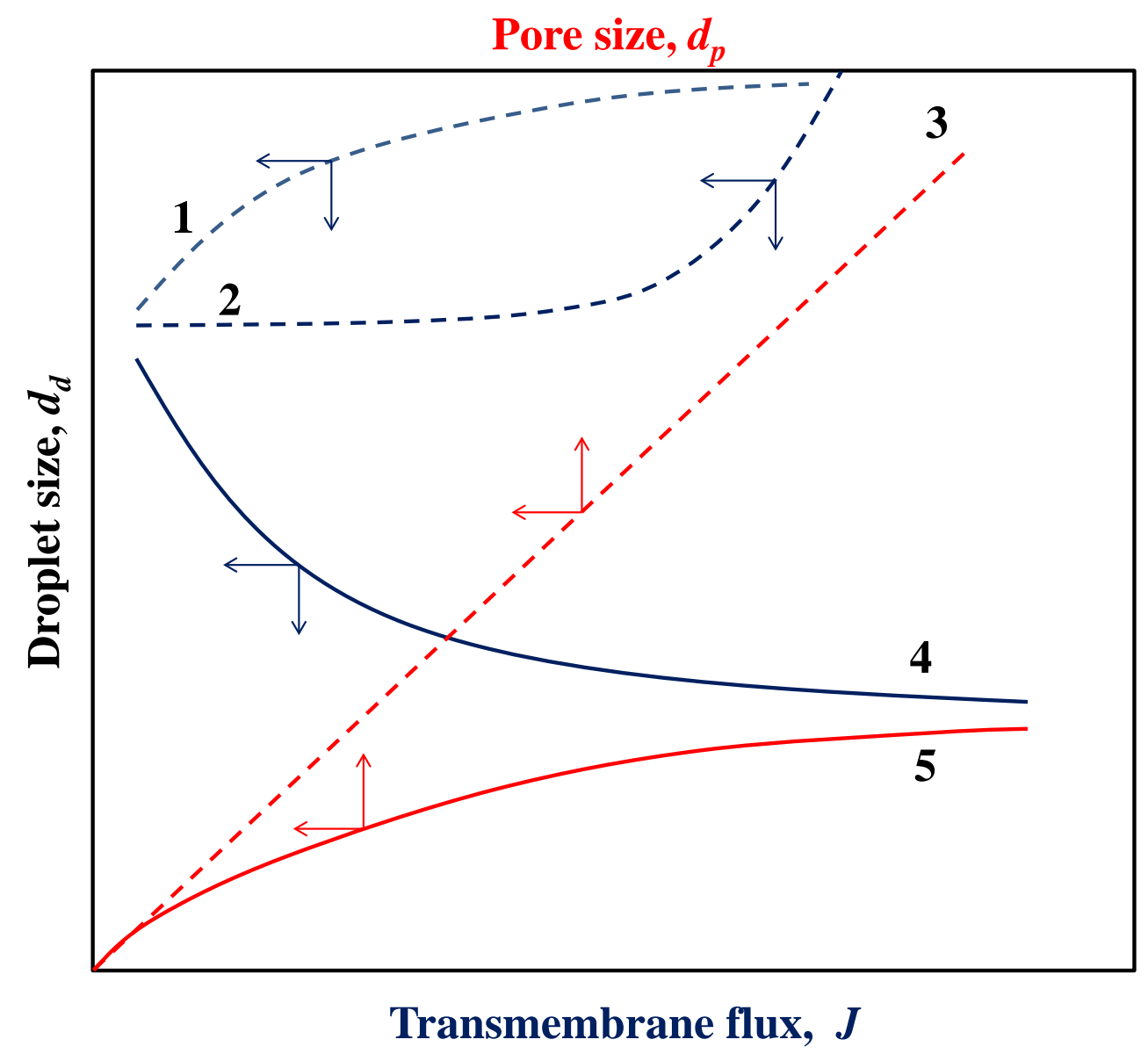

Figure 7 
(a) Internal gelation

(b) External gelation
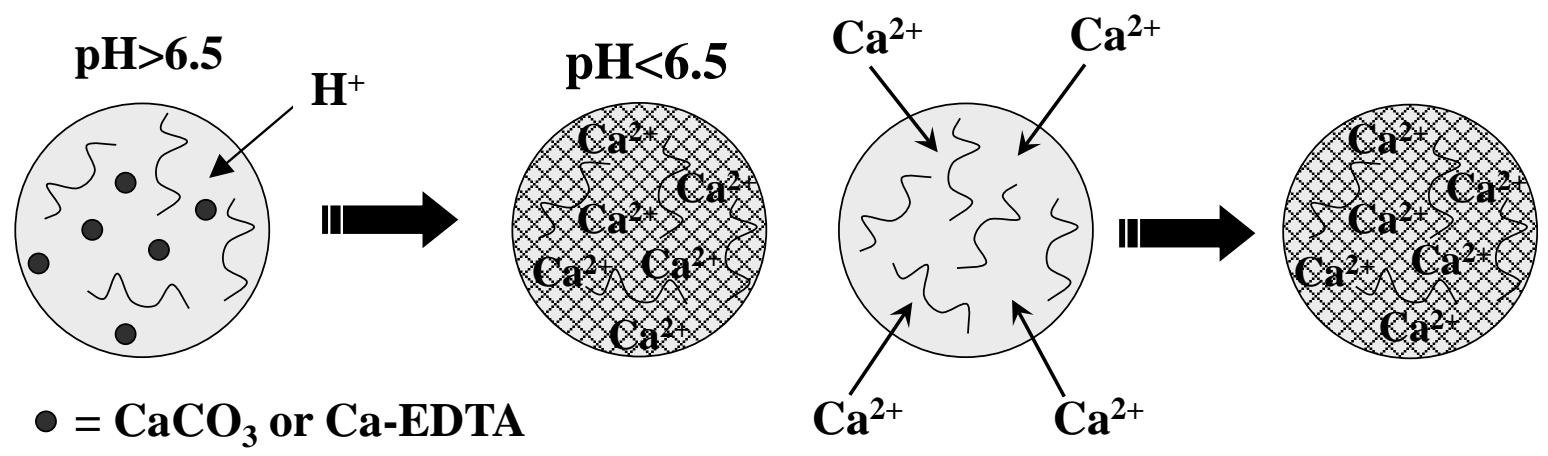

(c) Emulsion cooling

(d) Droplet coalescence

Agarose

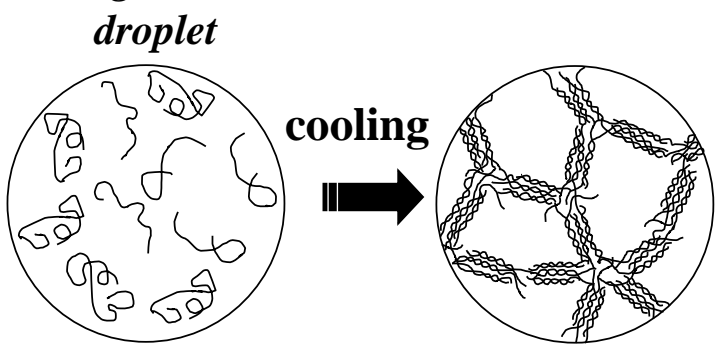

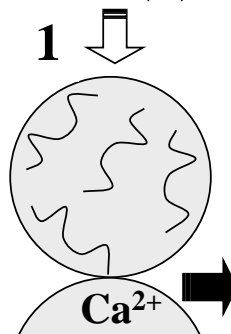

$\mathrm{Ca}^{2+} \mathrm{Ca}^{2+}$

$\mathrm{Ca}^{2+} \mathrm{Ca}^{2+}$

$\mathrm{Ca}^{2+}$

$2 \longdiv { \mho }$

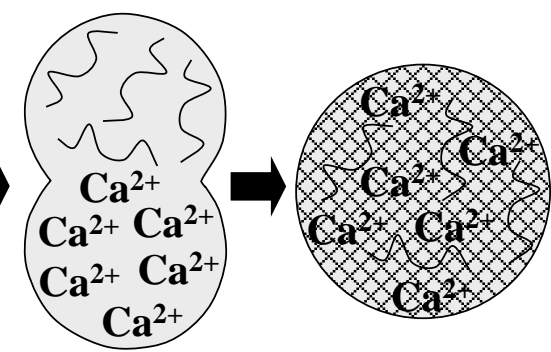

(e) Simultaneous core dissolution and shell crosslinking
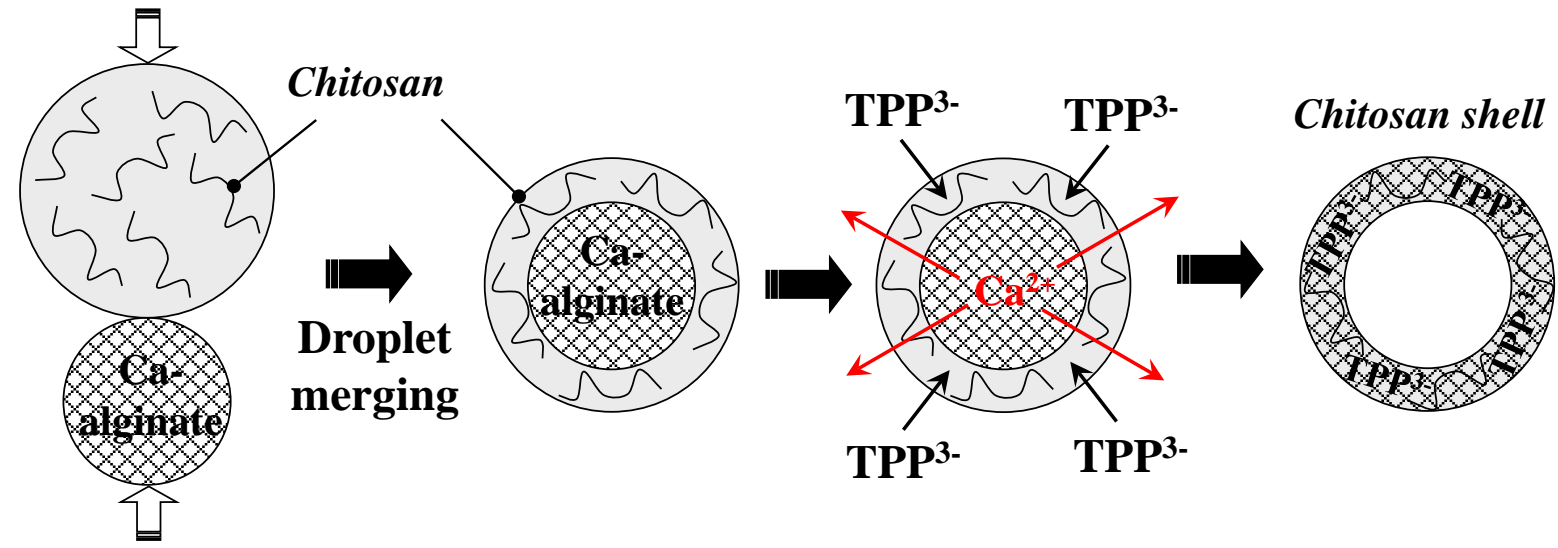

Figure 8. 


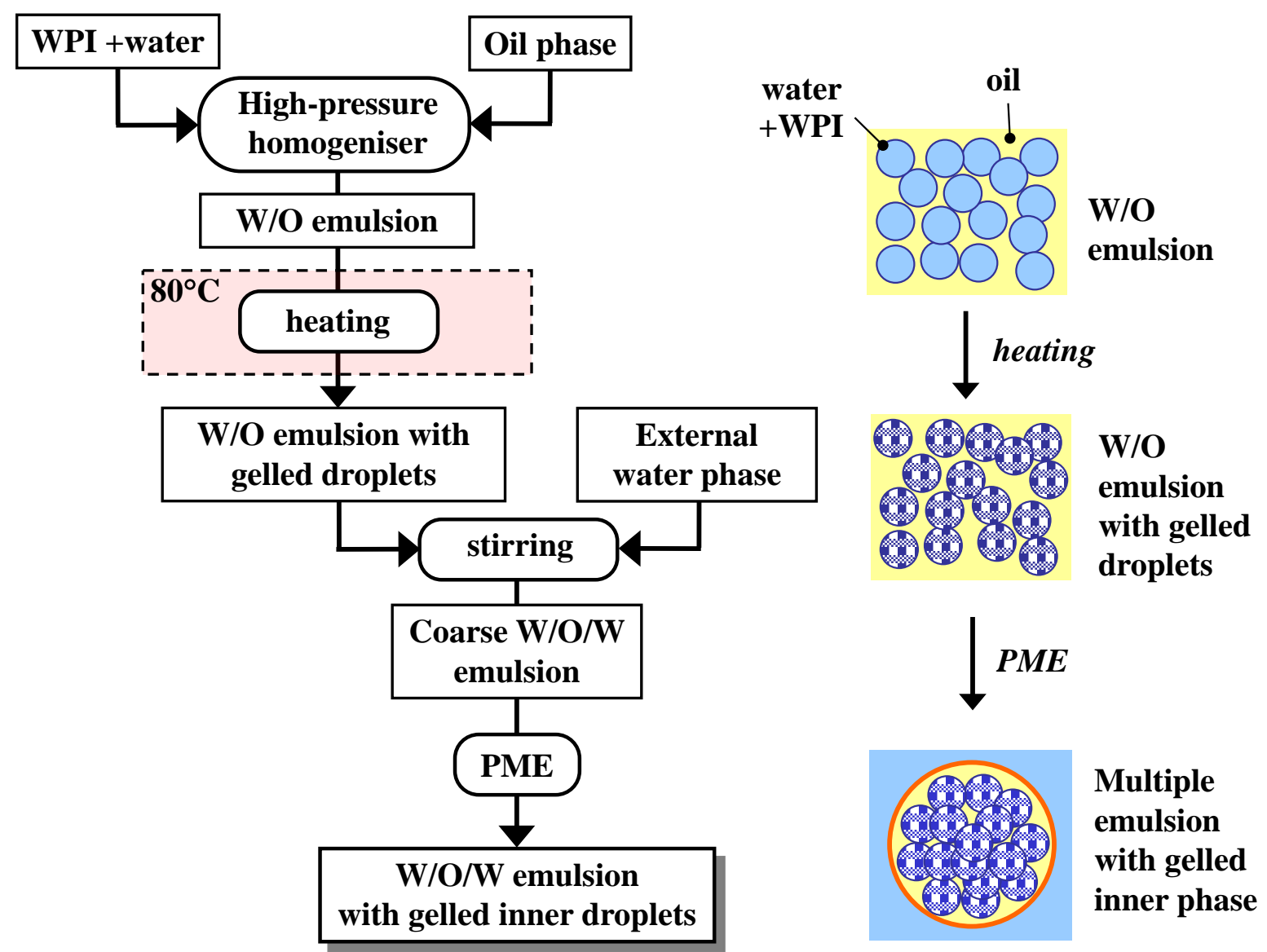

Figure 9 


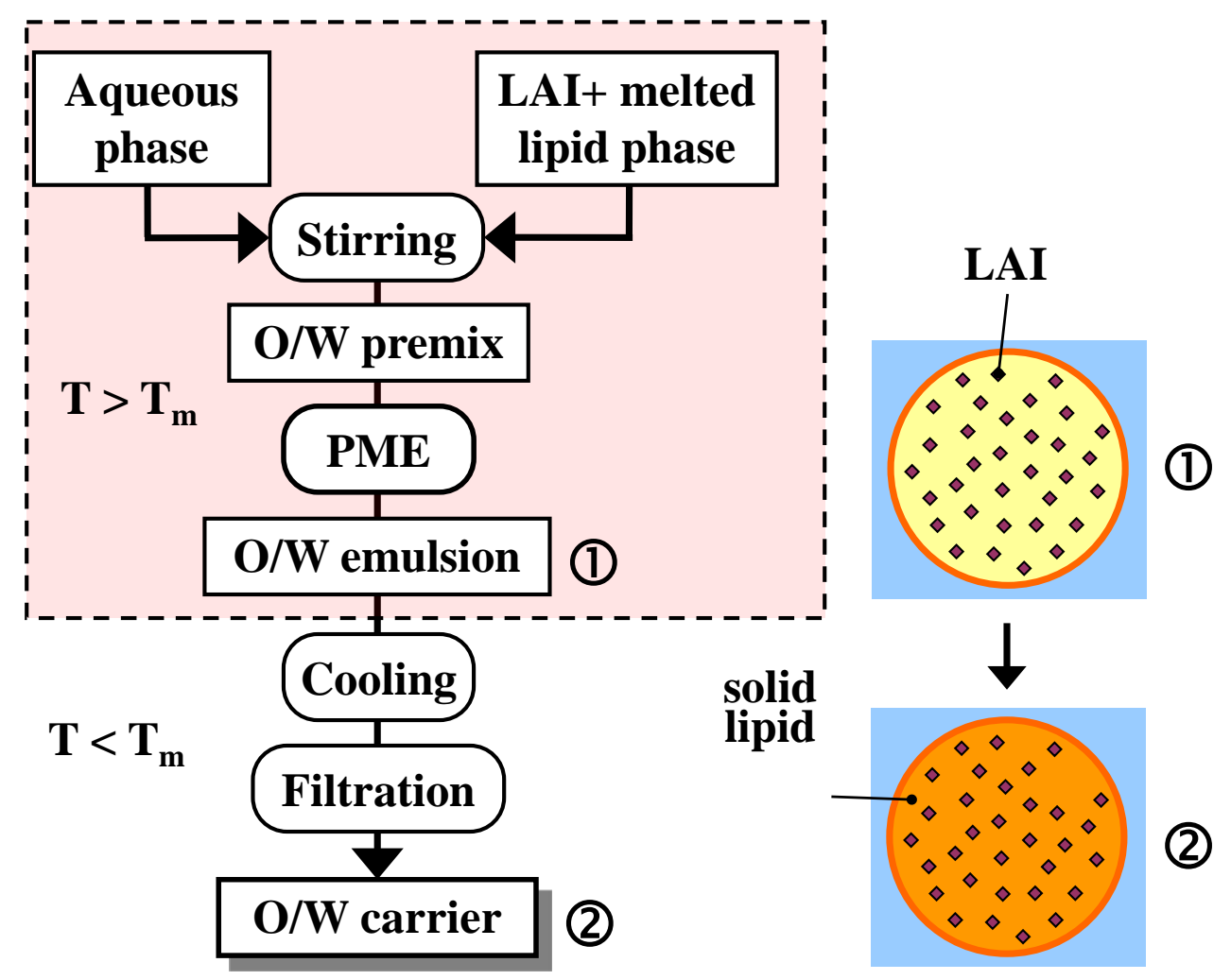

Figure 10 


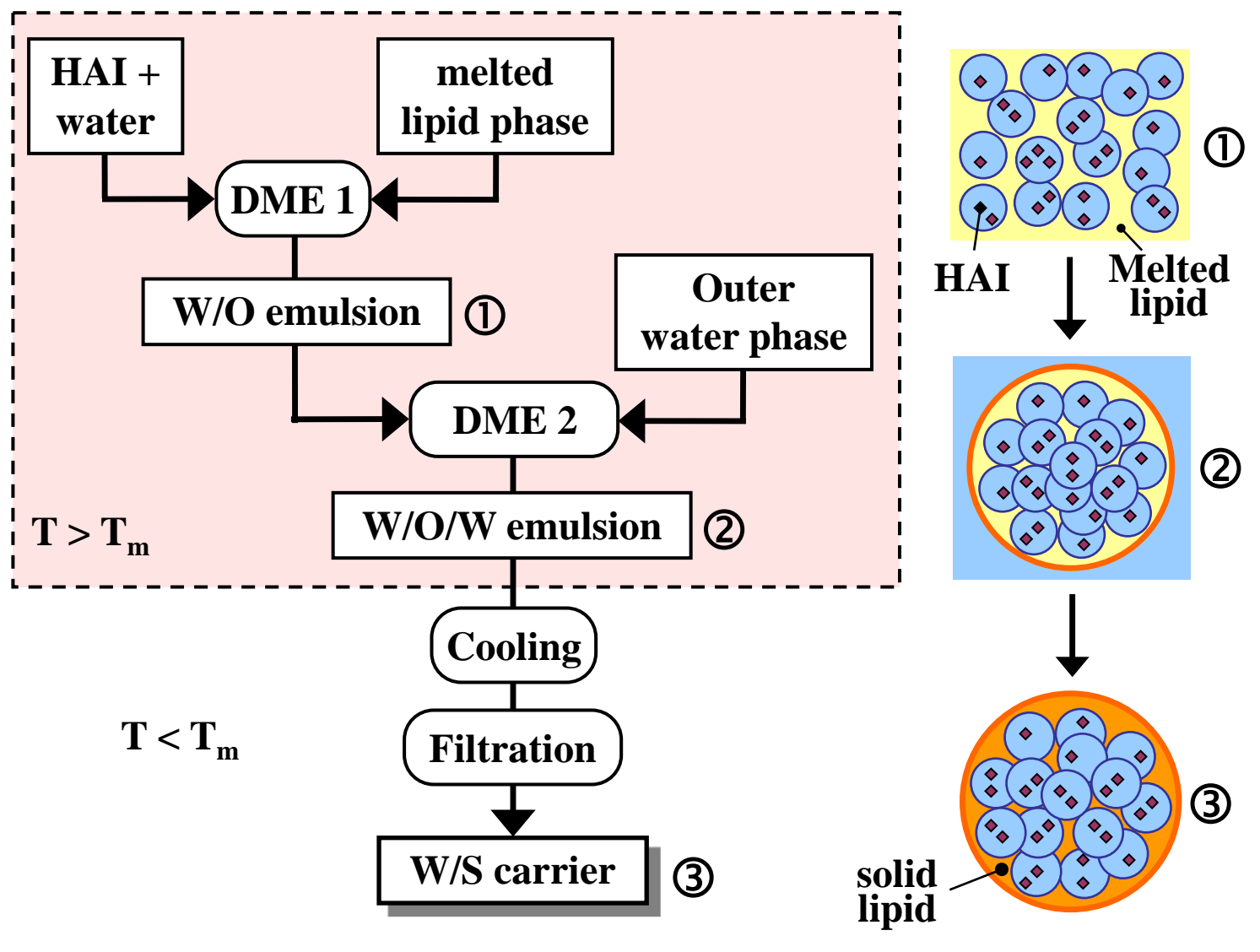

Figure 11 


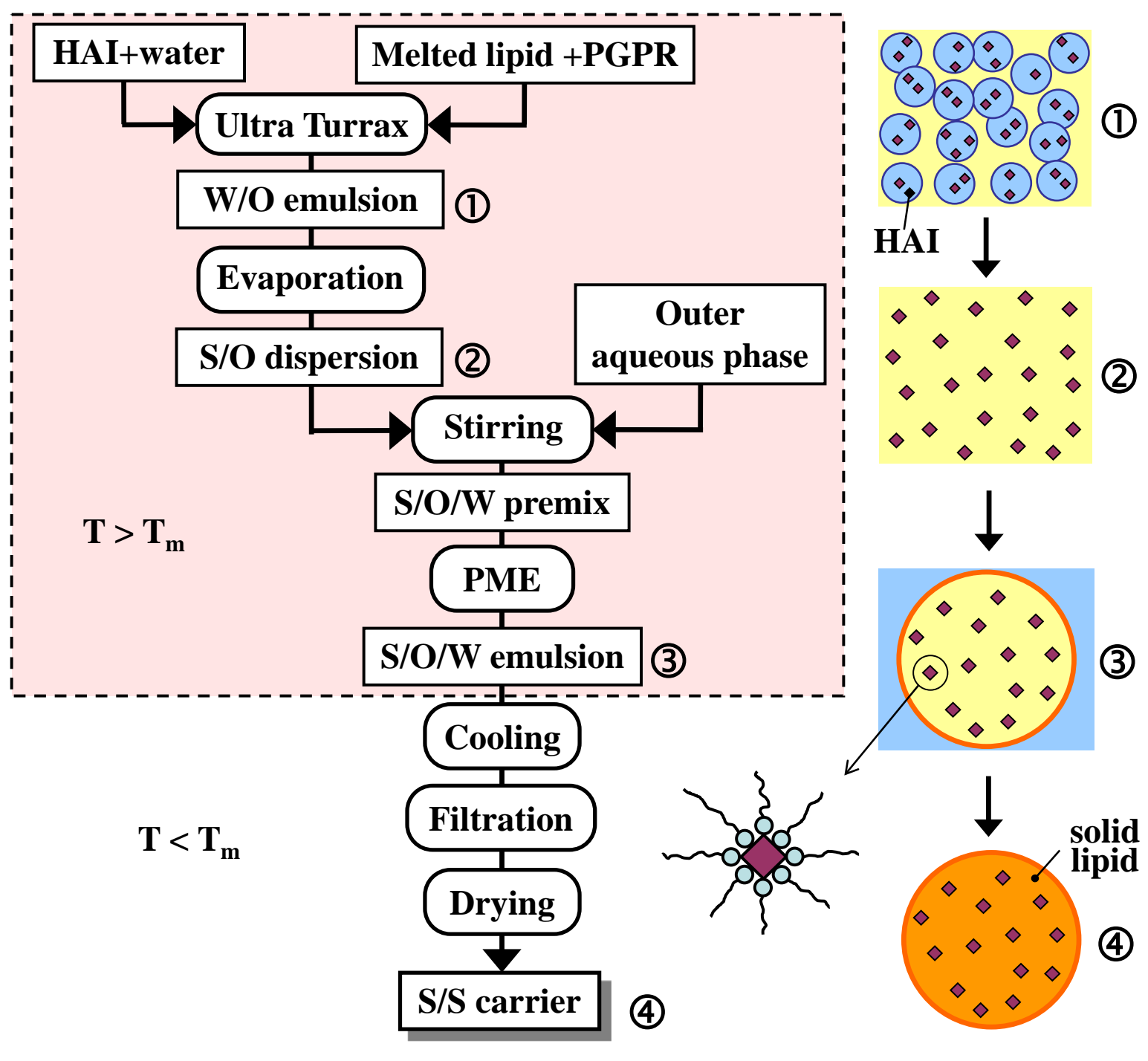

Figure 12 
(a) Coherent particle

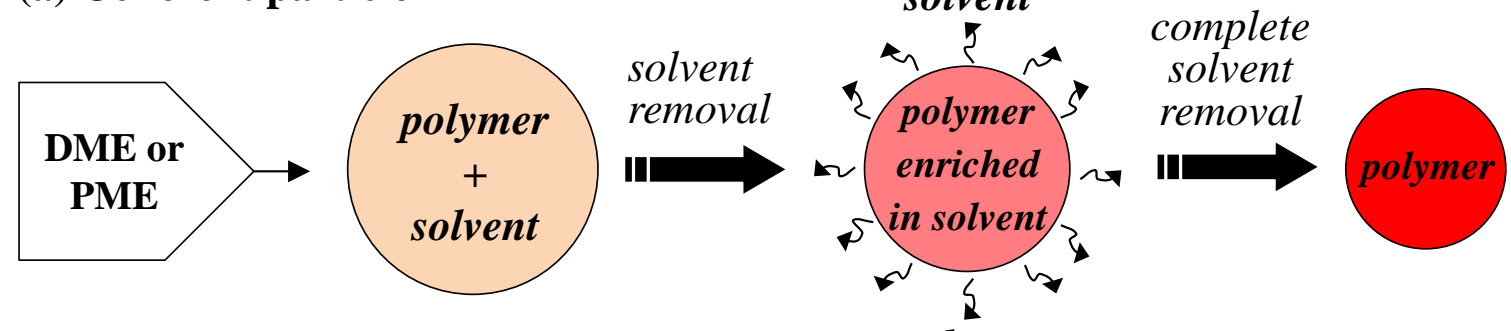

(b) Liquid-core/polymer-shell particle

$$
\text { solvent }
$$

solvent polymer-

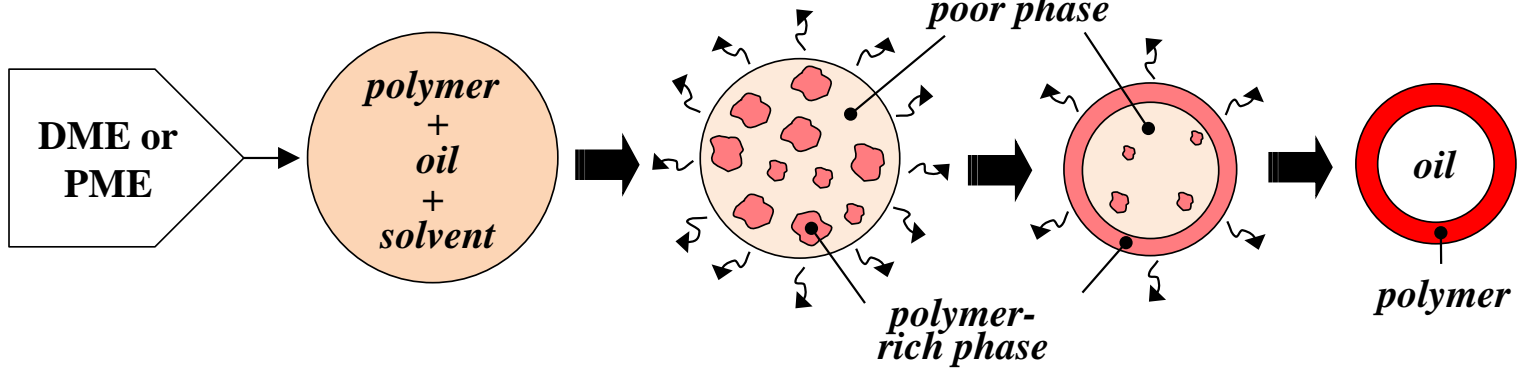

(c) Janus and non-spherical particles
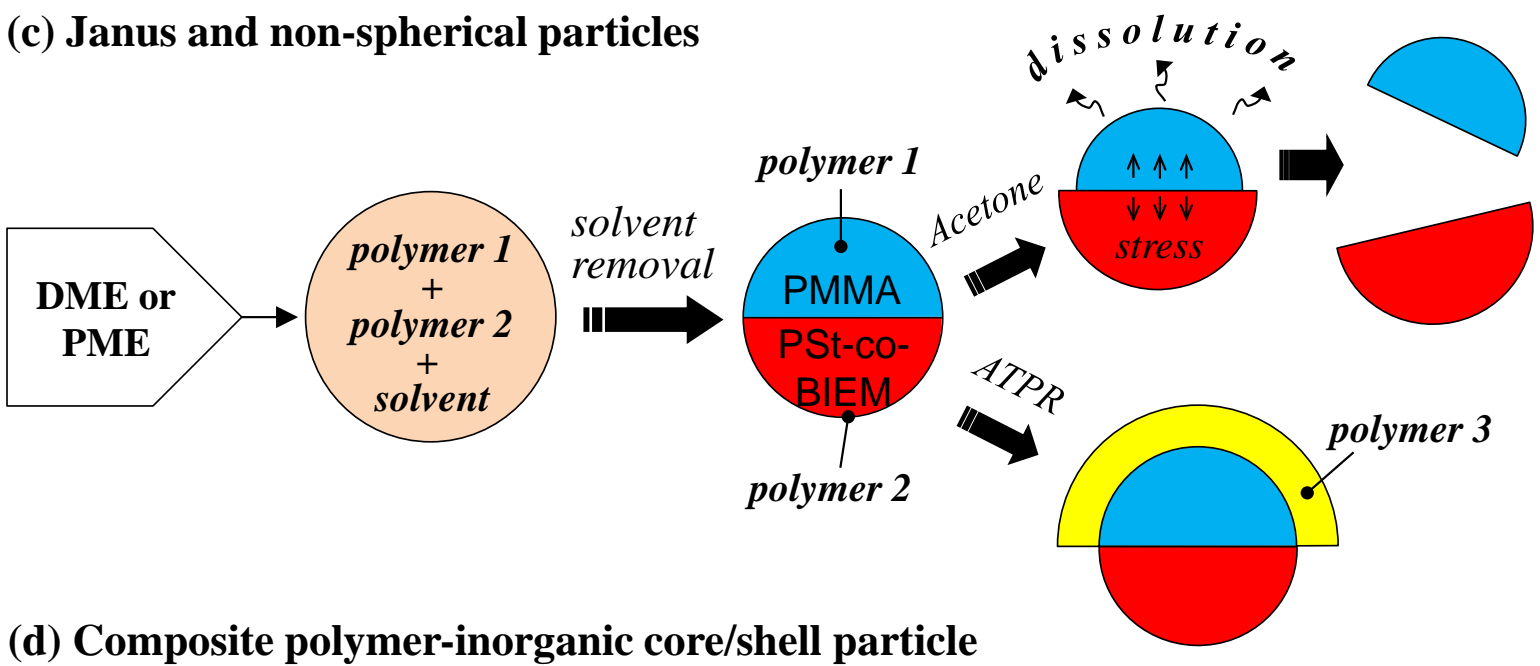

(d) Composite polymer-inorganic core/shell particle

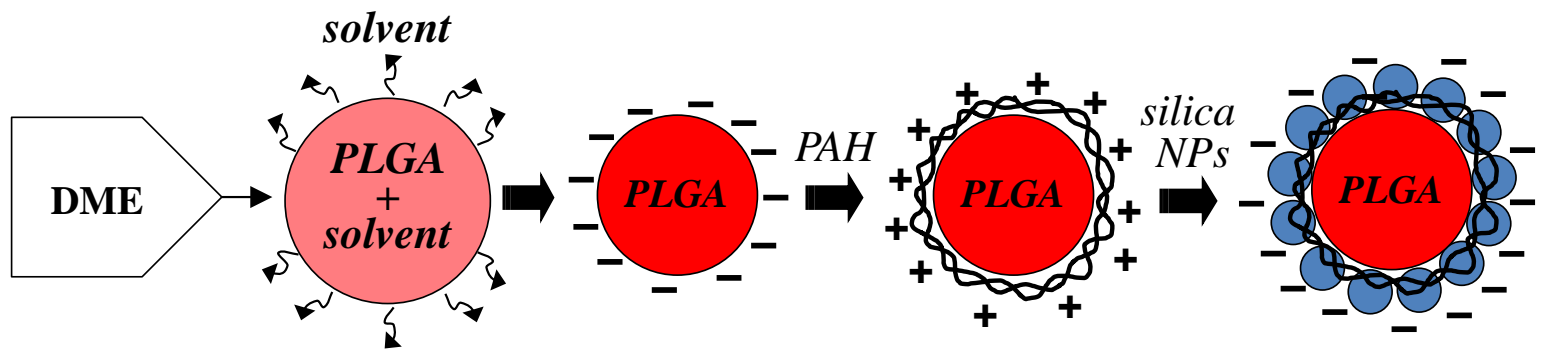

(e) Composite polymer-polymer core/shell particle

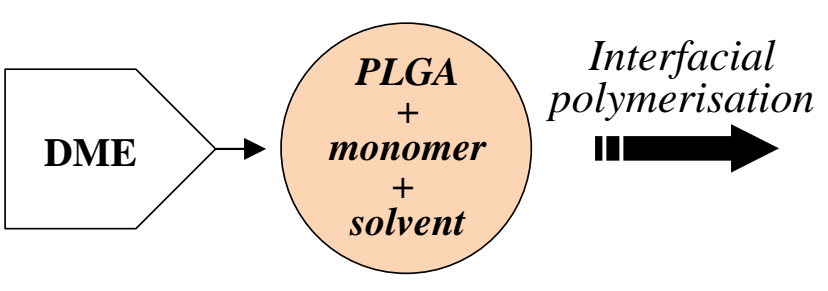

polymer-rich

Figure 13 phase

\section{PLGA \\ -rich \\ phase}

solvent removal

III

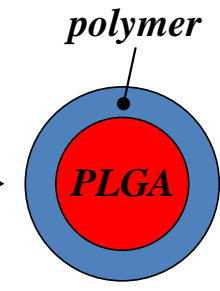


(a) Ultrasound contrast agent (UCA) particle polymer

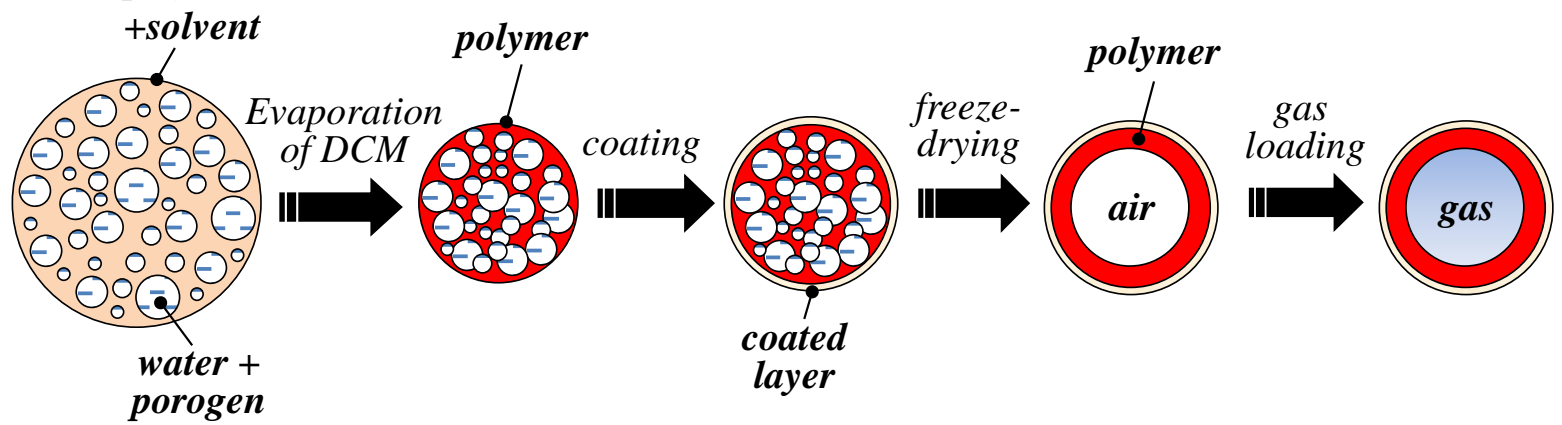

(b) Magnetite polymer particle prepared by in-situ magnetization polymer

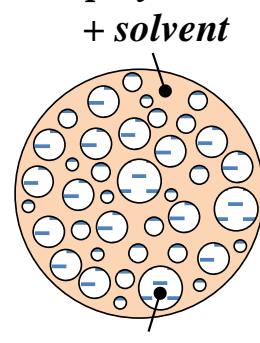

$\mathrm{FeCl}_{2}+\mathrm{FeCl}_{3}$
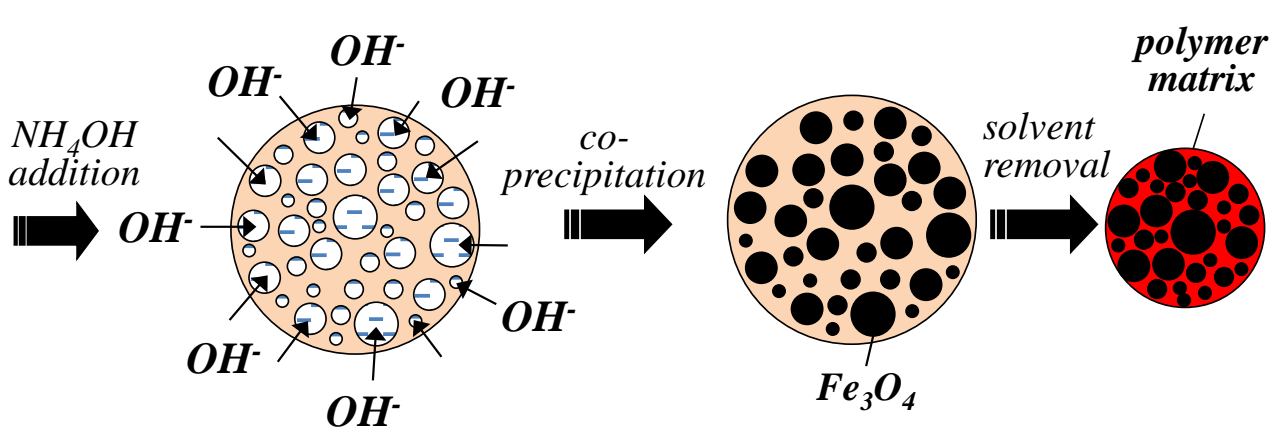

(c) Quantum-dot (QD) embedded barcode particle

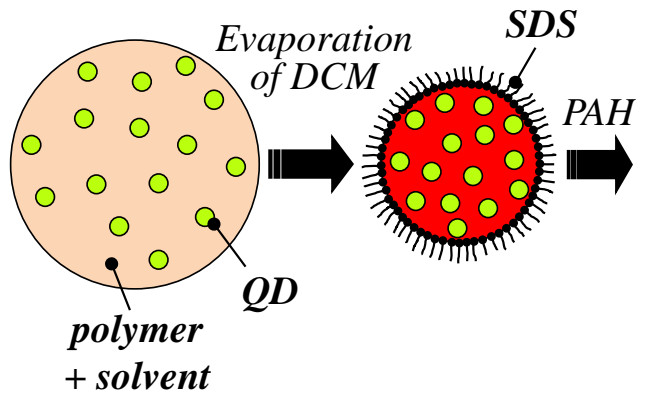

(d) Silica-coated nanoparticle (NP) cluster

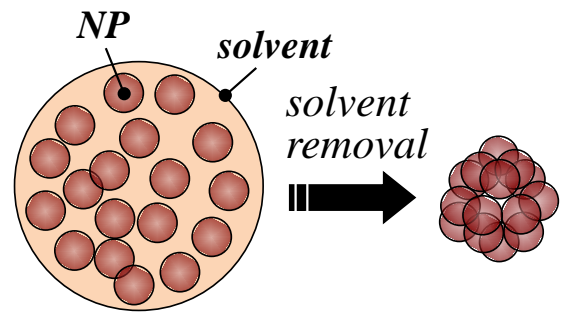

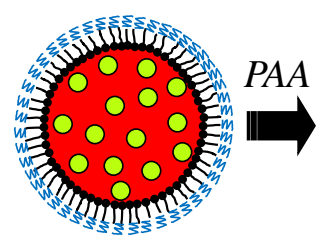
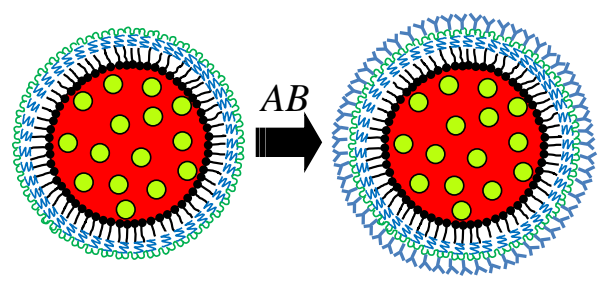

TEOS hydrolysis

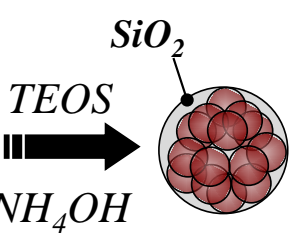

\section{Condensation}

$-\stackrel{1}{S} \mathbf{i}-\mathrm{OR}+-\stackrel{\mathrm{I}}{\mathrm{i}} \mathbf{i}-\mathrm{OR} \stackrel{-\mathrm{HOH}}{\longrightarrow}-\stackrel{1}{\mathrm{~S}} \mathrm{i}-\mathrm{O}-\stackrel{\mathrm{I}}{\mathrm{S}} \mathbf{i}-$

Figure 14 


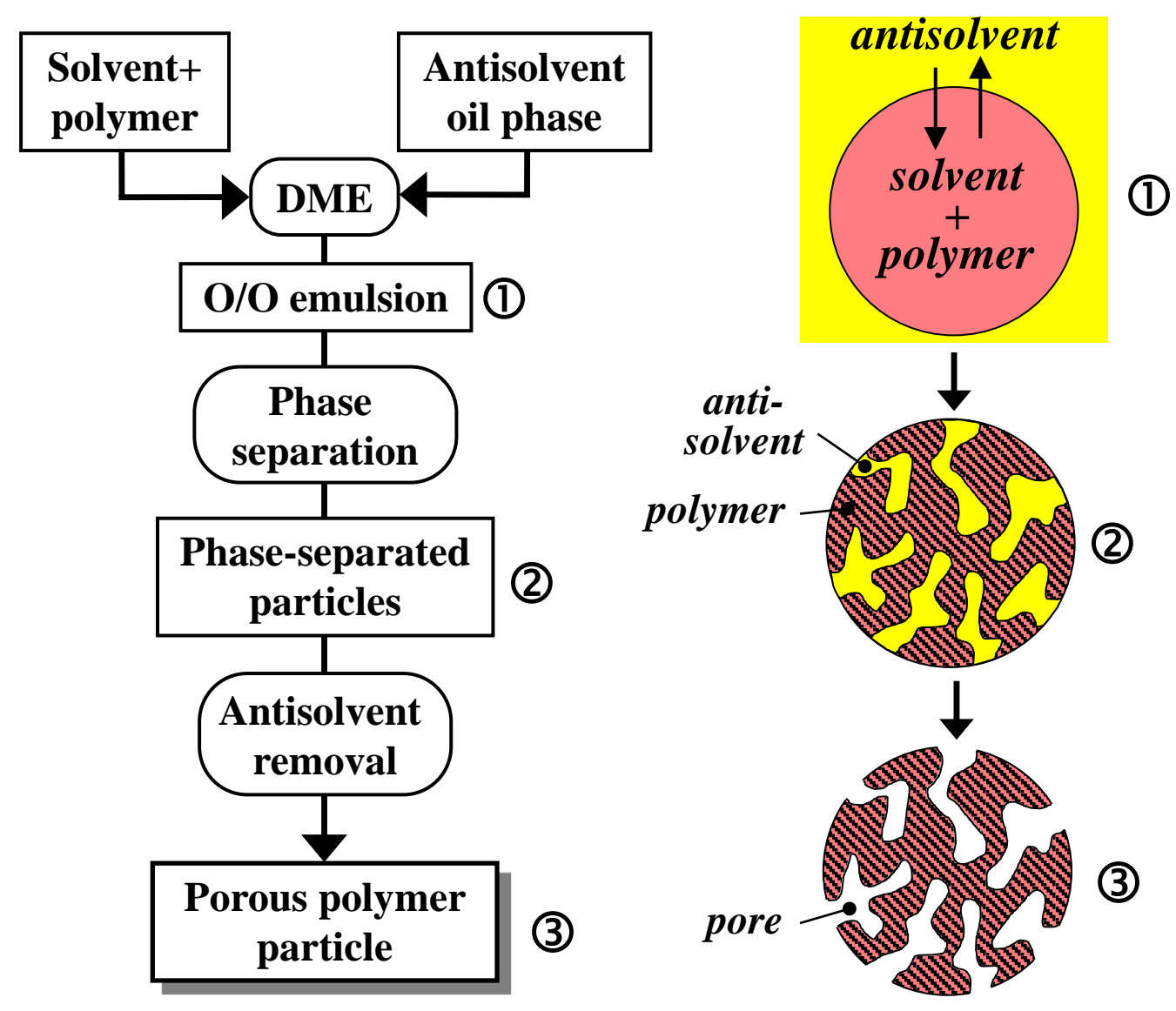

Figure 15 
(a) Phase separation

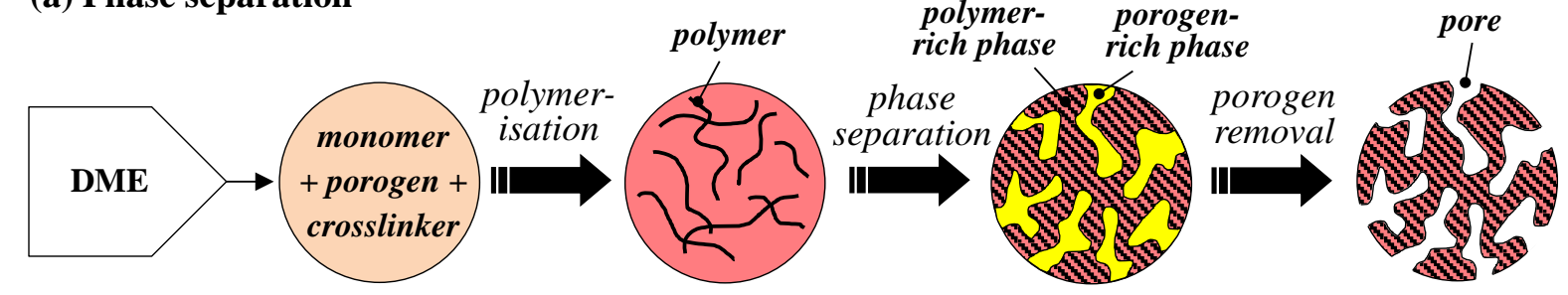

(b) Hypercrosslinking
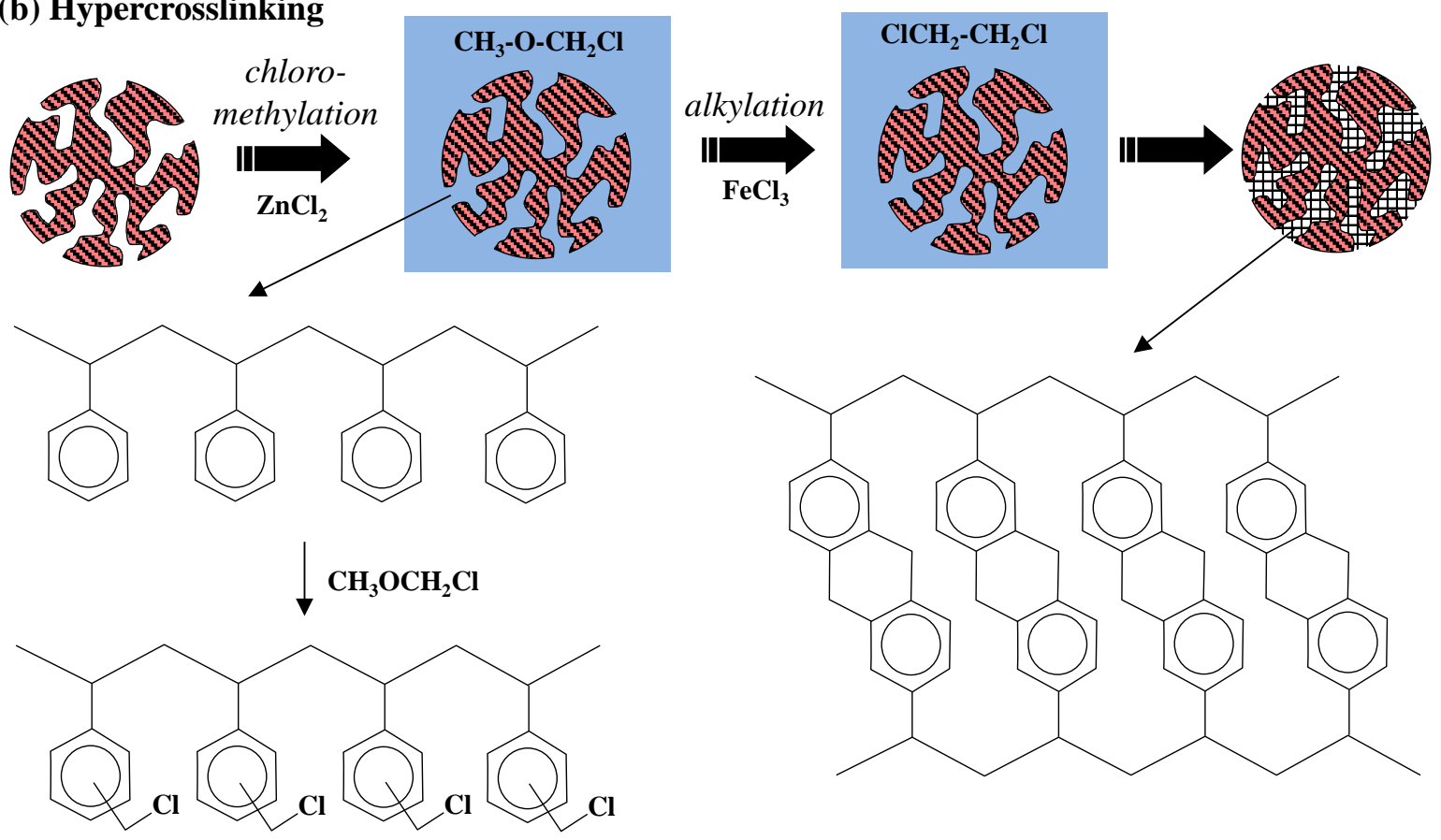

Figure 16 


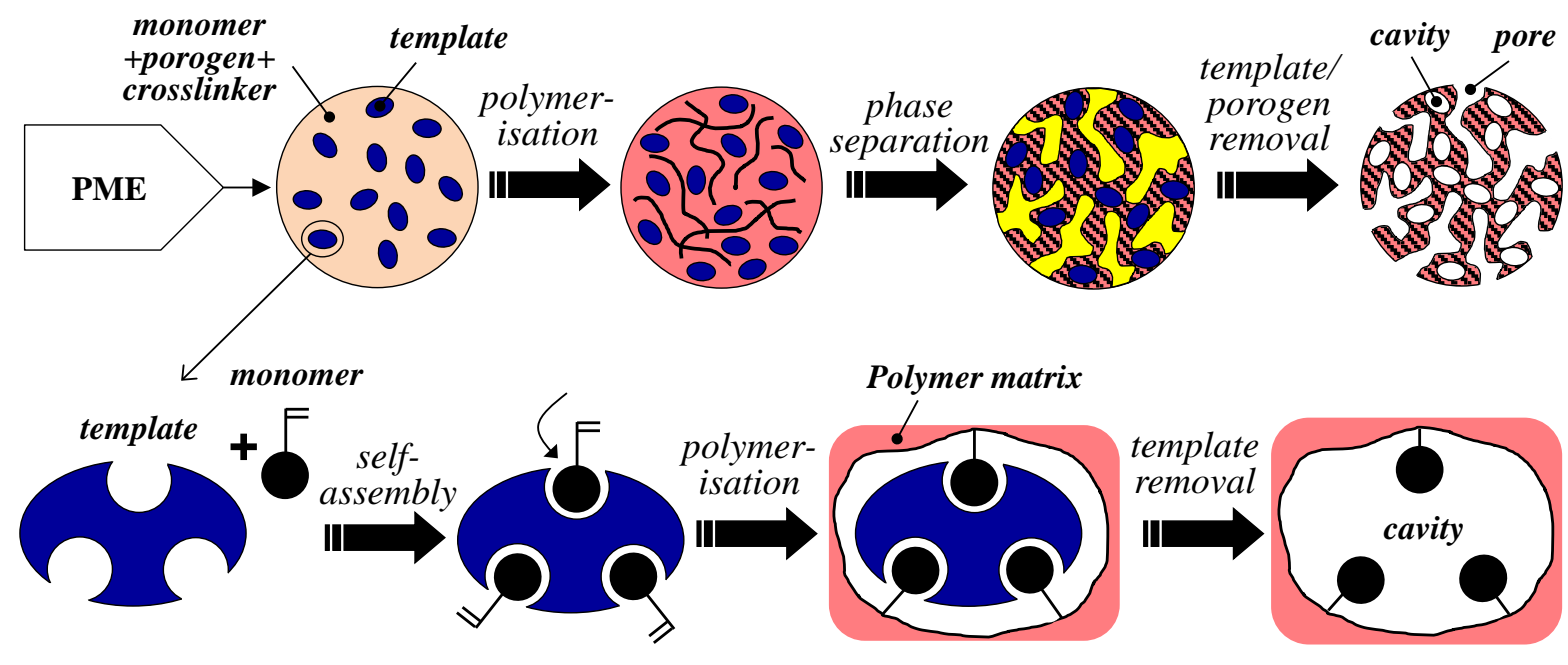

Figure 17 
(a) One-stage suspension polymerisation

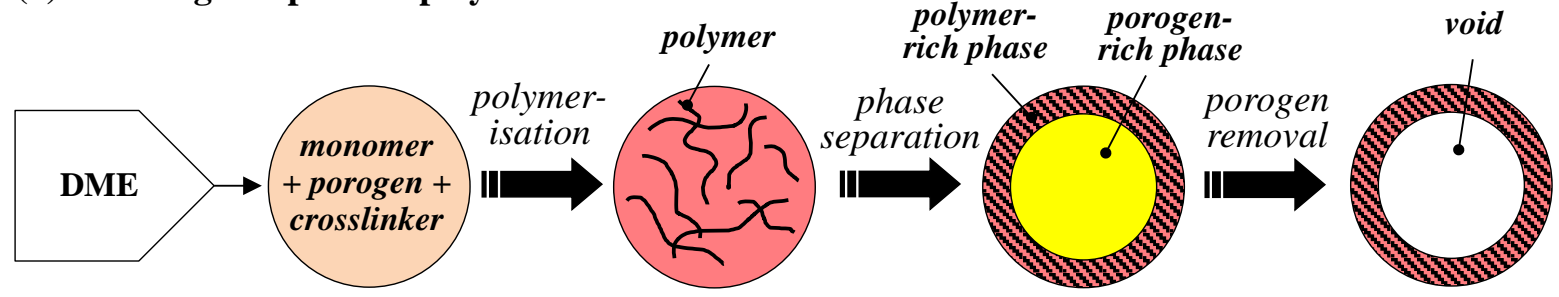

(b) Two-stage suspension polymerisation

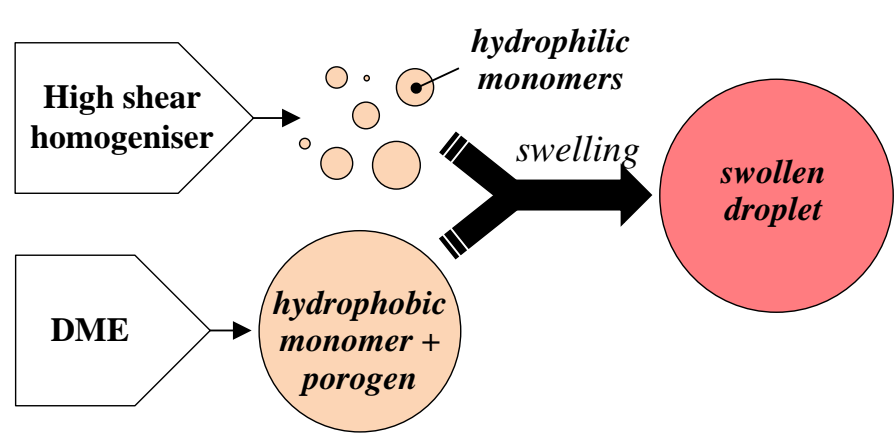


(a) Interfacial polycondensation (IP) and graft polymerisation (GP)
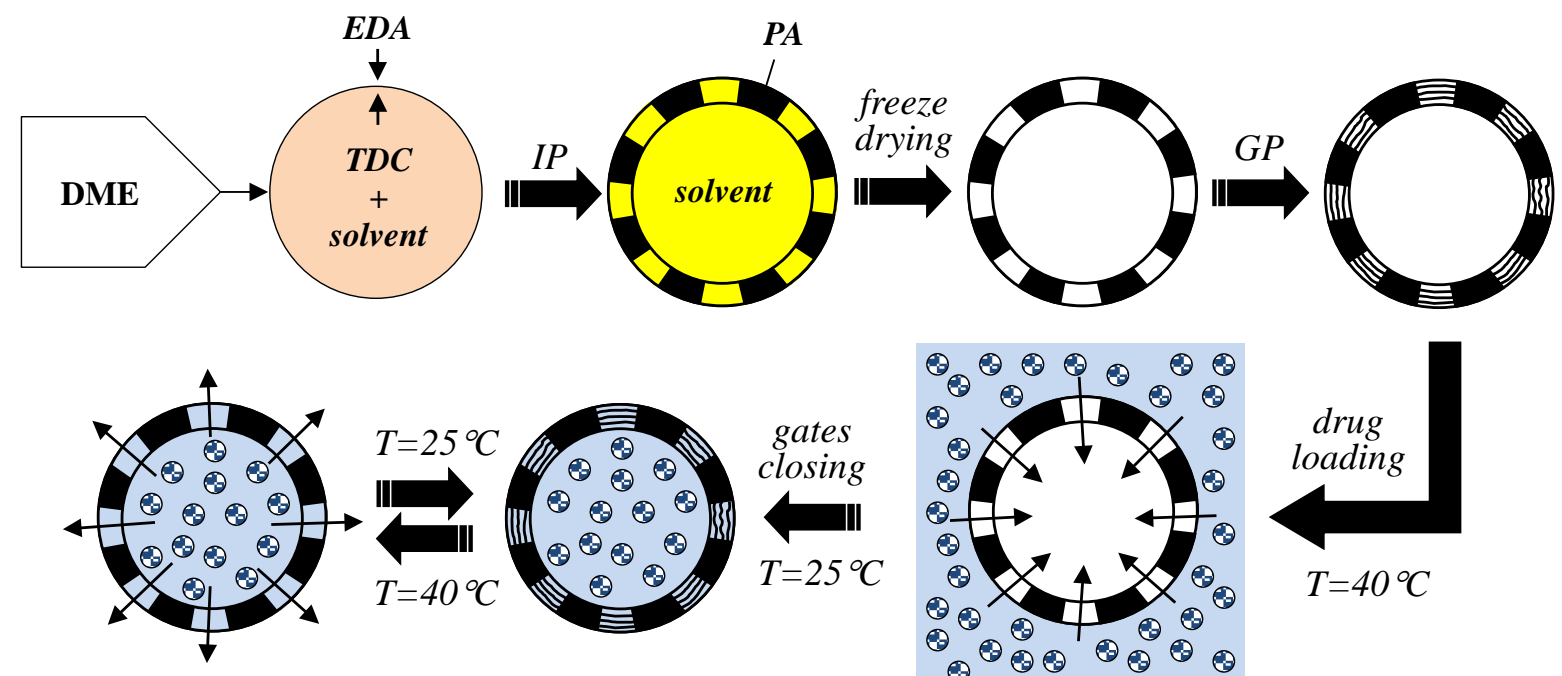

(b) In situ polymerisation (ISP)

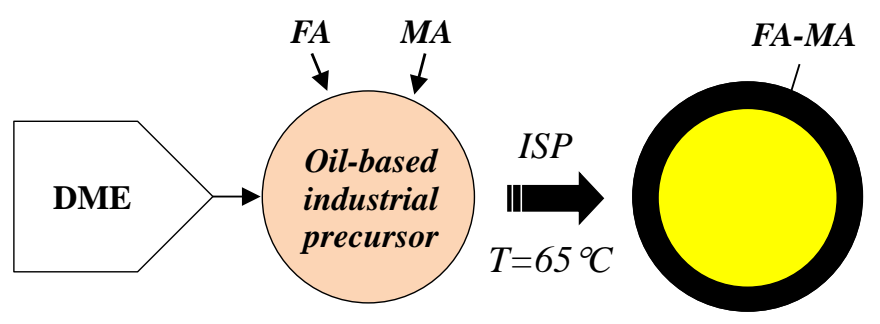

Figure 19 
(a) Mini-emulsion polymerisation
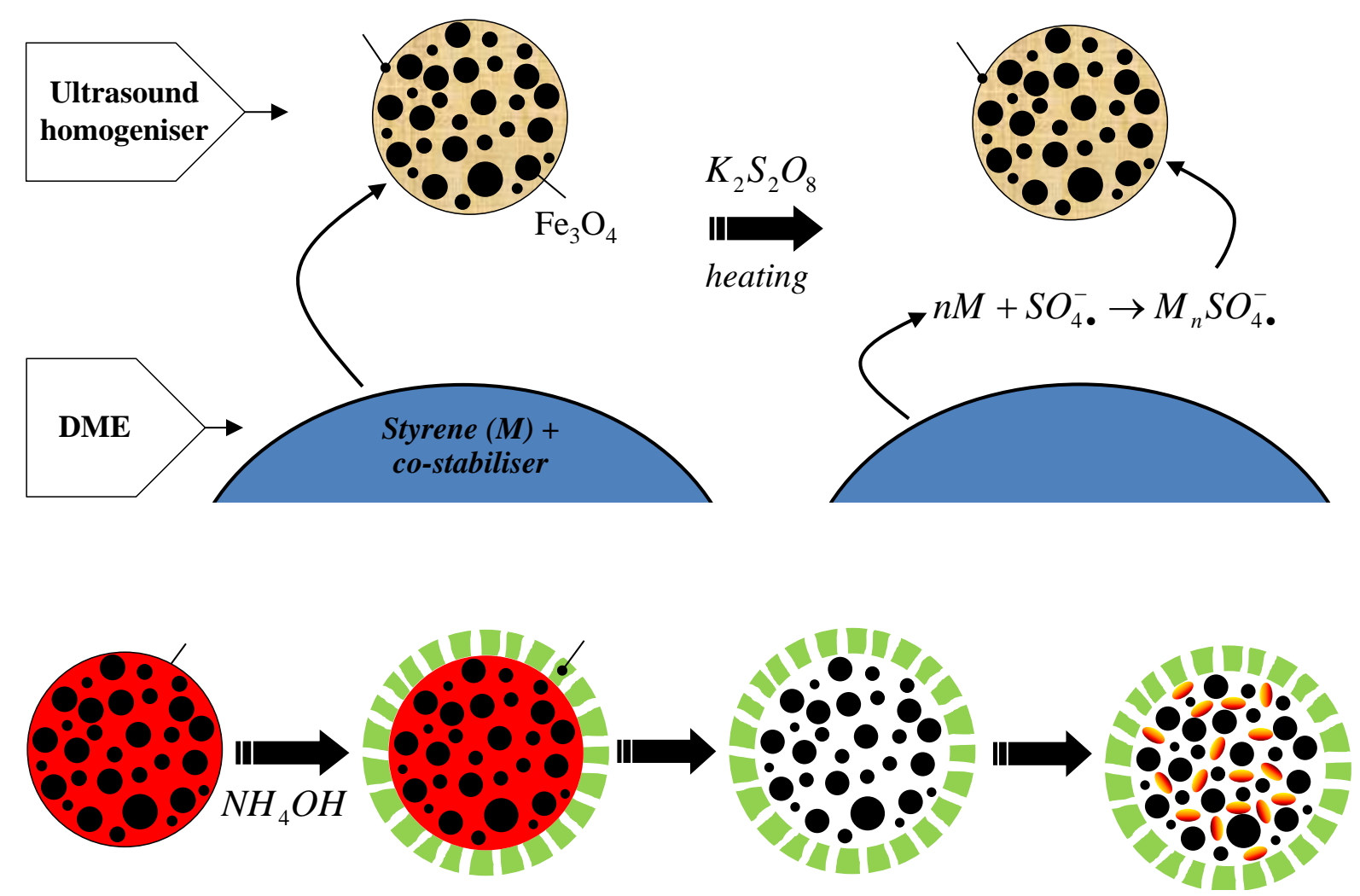

Figure 20 


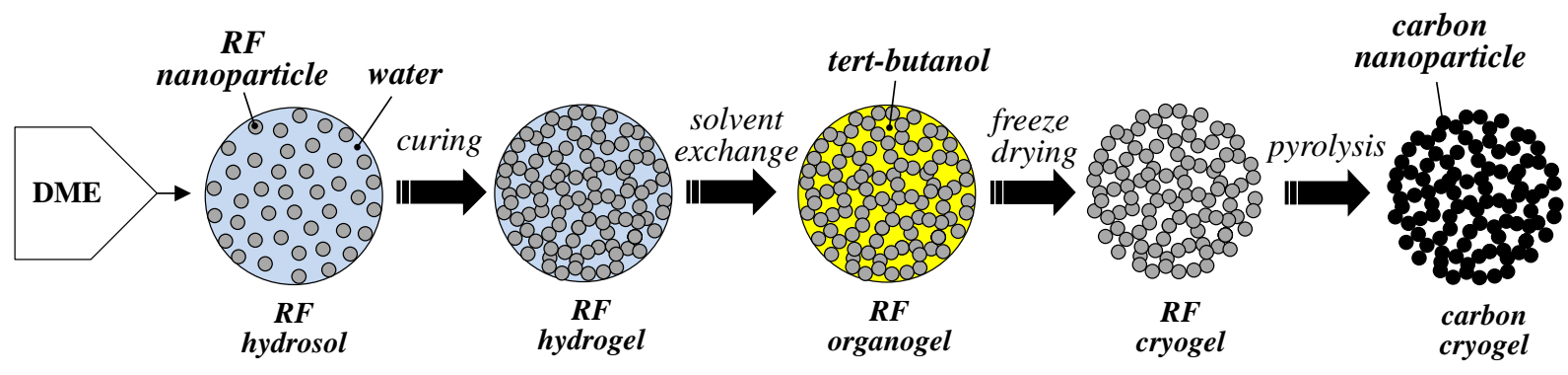

Figure 21 

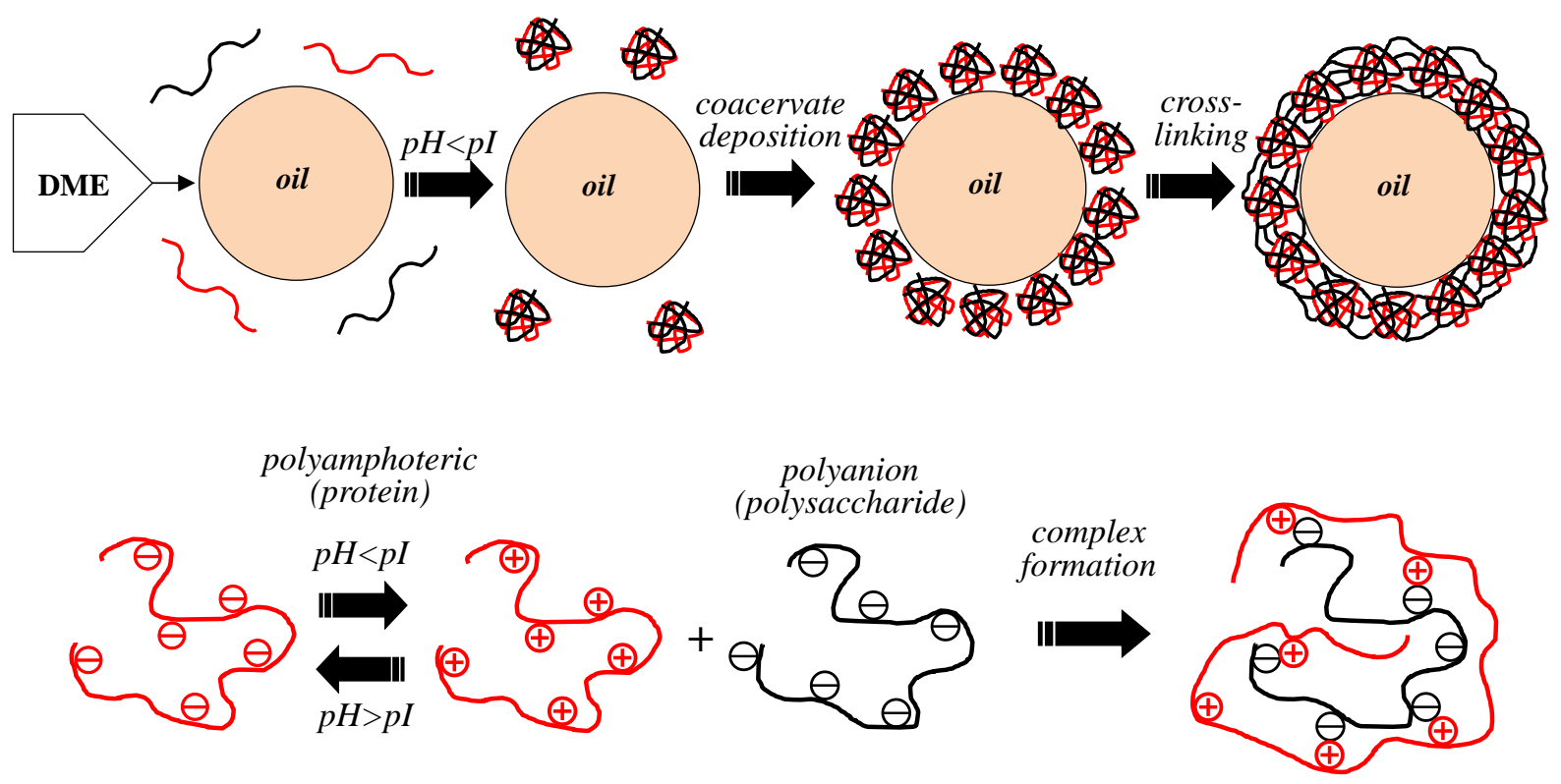

Figure 22 
(a) Three-layer emulsion

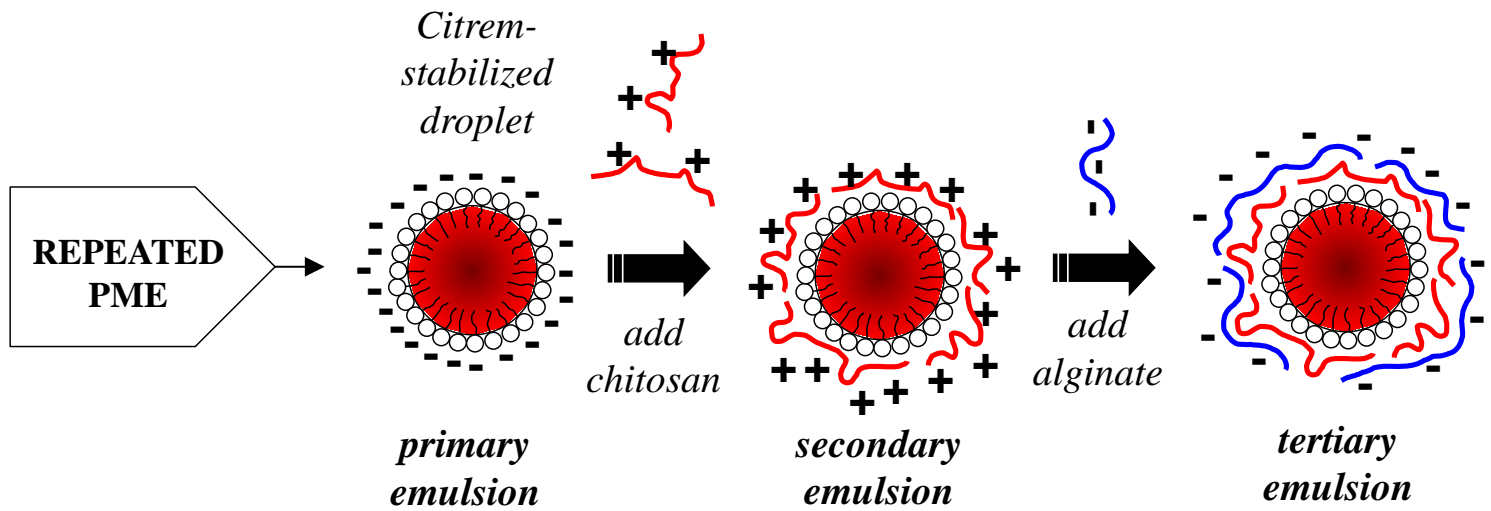

(b) Two-layer emulsion prepared by surfactant displacement

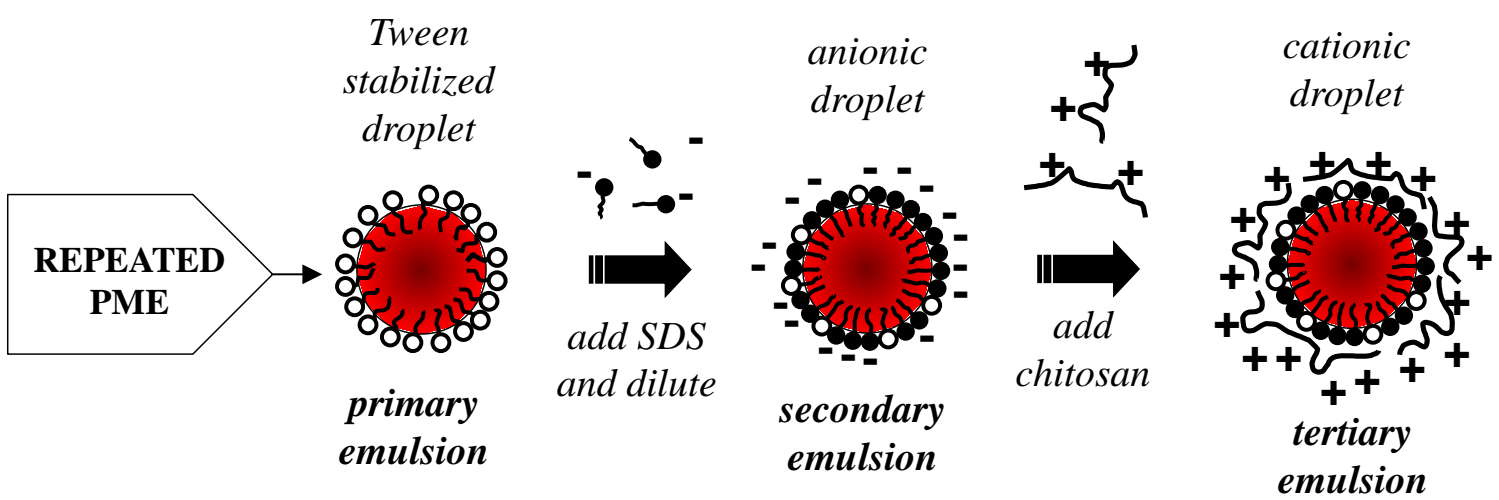

(c) Two-layer emulsion prepared by two-step mixing

$$
B L G-
$$

stabilized

droplet

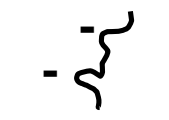

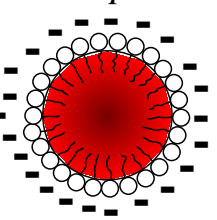

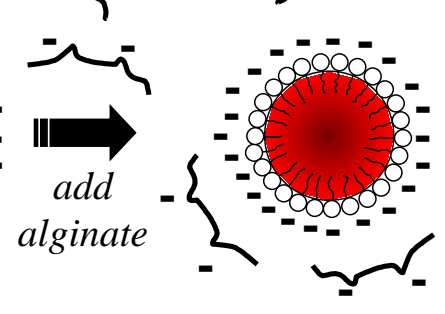

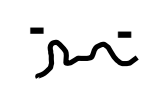

lower pH
ת

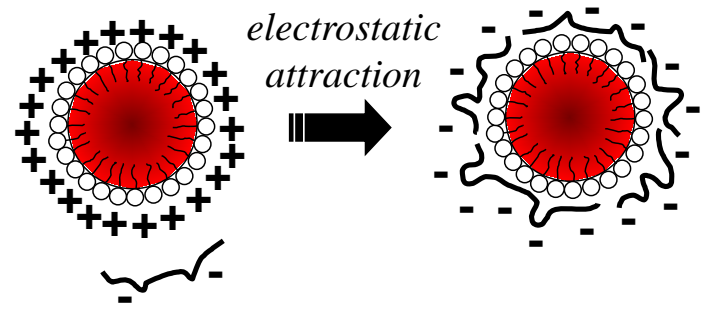

Figure 23 
(a) Colloidosomes prepared by DME and internal cross-linking of Pickering particles
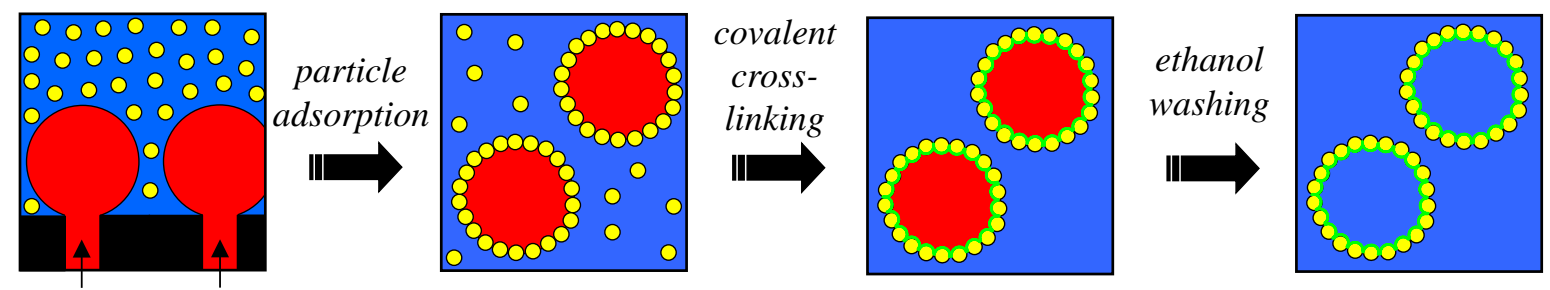

oil+crosslinker

(b) Colloidosomes prepared by PME and polymer deposition onto Pickering particles
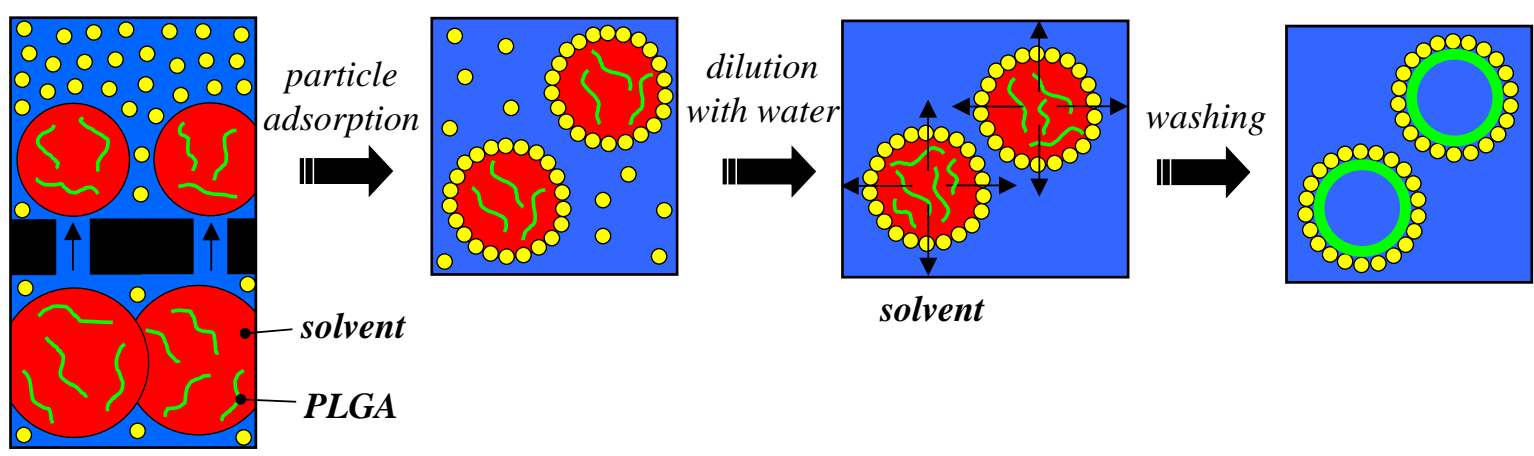

solvent

Figure 24 